\title{
The Oliver Bolton Collection of Dart and Spear Points from Camp County, Texas, and Other Remarks
}

Robert L. Turner

Follow this and additional works at: https://scholarworks.sfasu.edu/ita

Part of the American Material Culture Commons, Archaeological Anthropology Commons, Environmental Studies Commons, Other American Studies Commons, Other Arts and Humanities Commons, Other History of Art, Architecture, and Archaeology Commons, and the United States History Commons

Tell us how this article helped you.

This Article is brought to you for free and open access by the Center for Regional Heritage Research at SFA ScholarWorks. It has been accepted for inclusion in Index of Texas Archaeology: Open Access Gray Literature from the Lone Star State by an authorized editor of SFA ScholarWorks. For more information, please contact cdsscholarworks@sfasu.edu. 
The Oliver Bolton Collection of Dart and Spear Points from Camp County, Texas, and Other Remarks

\section{Creative Commons License}

\section{(c) (1) \&}

This work is licensed under a Creative Commons Attribution-NonCommercial 4.0 International License 


\title{
The Oliver Bolton Collection of Dart and Spear Points from Camp County, Texas, and Other Remarks
}

\author{
Robert L. Turner, Jr.
}

\begin{abstract}
This article analyzes the Bolton Collection of 1384 lithic artifacts, including dart and spear points from the Paleoindian through the Woodland periods. The analysis places the points in the sequence used by Perttula (2013). The points are compared with those from the middle Sabine River basin counties (Perttula and Young 2012) as well as the analysis of the Archaic points of the Cypress Creek drainage basin (Thurmond 1990). In addition, the Archaic and Woodland population density of Camp County based on the proportional frequency of projectile points of known age is compared with that of the middle Sabine River basin counties and the Cypress Basin. Additional comparisons are made with archaeological sites in the Post Oak Savanna to the north and west and in the Blackland Prairie to the west.
\end{abstract}

\section{The Collection}

During the 1930s and early 1940s, Mr. Oliver Bolton acquired a collection of Indian artifacts. He was in the mercantile business in Pittsburg, Texas, the county seat of Camp County. Pittsburg had a population slightly under 3,000 and the Camp County population was slightly over 10,000 at that time. Camp County is the third smallest county in Texas, covering an area of 297.5 square miles. Mr. Bolton's collection was acquired primarily from county farm boys. Each Saturday, the rural population came to town for their shopping and socializing. At that time, many were still using wagons as the primary means of transportation. Boys, and perhaps girls, would bring their artifacts to Mr. Bolton, who would purchase them. Thus, a few dart points would provide enough cash for a cowboy movie at the State Theatre where the show cost 10 cents, and popcorn, soft drinks, and a candy bar were 5 cents each.

During this time period in East Texas, most agriculture consisted of row crops with cotton as the money crop and corn for food and livestock. Thus, the fields were plowed several times a year. After a rain, artifacts were exposed on the plowed surface. One of the boys who brought artifacts to Mr. Bolton was Sherwood Dunavant, who I interviewed in 2010 to confirm these events.

In this article, only the Bolton dart and spear points and other lithic tools are analyzed although other artifacts from the county may be mentioned. Unfortunately, the arrow points, except for 14 of them, were given to an unknown woman by Mr. Bolton's widow prior to 1948. I acquired the remainder of this collection in 1948 and it has remained intact. The lithic artifacts consist of 1180 classified dart points, 107 broken and unclassified points, 20 spear points and the 14 arrow points mentioned above. In addition, there are 31 bifaces, two large chert knives, eight drills and scrapers, one Albany scraper, and one large Galt biface. The spear points are mostly of the Pogo type as identified by Suhm and Krieger (1954). The Paleoindian lanceolate points were also mounted as spears but in this article they are referred to as dart points.

Other artifacts from the collection include eight Titus phase pottery vessels from the Harold Williams site (41CP10, see Turner et al. 2002); three additional vessels without positive provenance (except Camp County); 
10 hematite axes (Turner 2006); one hematite boatstone/pendant; one hematite boatstone; and one hematite pendant. The boatstone and pendant are in the Northeast Texas Rural Heritage Museum in Pittsburg.

Figure 1 indicates the location of Camp County within Texas and also shows that all county roads funnel into Pittsburg where Mr. Bolton assembled his collection. Thus, the collection should be representative of what is present archaeologically in the county. Figure 1 also shows the location of several archaeological sites mentioned in this article.

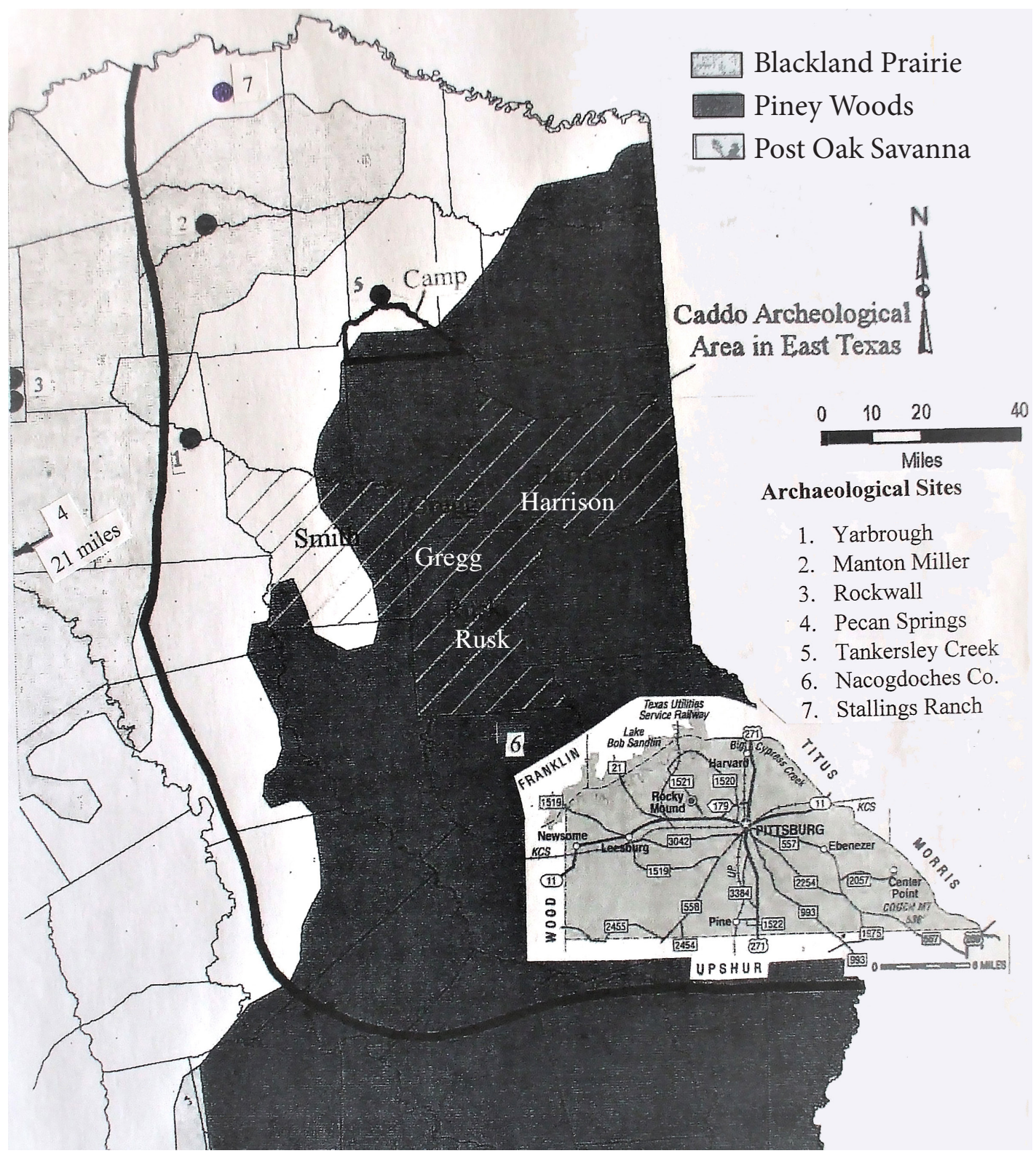

Figure 1. The location of Camp County and several archaeological sites in Northeast Texas. 


\section{The Temporal Position of the Points}

Figure 2 is an arrangement of the Bolton dart and spear point types superimposed on a temporal chart. This shows the various eras from the Paleoindian period through the Woodland period and the types and quantity of the Bolton points from each. This chart is patterned after that of Perttula (2013b:35 and Figure 2, 2016:72 and Figure 4) and Carpenter and Paquin (2010).

The numeral under each point in Figure 2 is an identifying number. Carpenter and Paquin (2010) assigned a number to 93 points identified by type name. Perttula $(2013,2016)$ added five additional point types: 94, Graham Cave; 95, Breckenridge; 96, Hidden Valley; 97, Rice Lobed; and 98, Jakie. I have added additional points to this list: These are 99, Hill point (a new type I propose which will be explained later); 100, Calf Creek; 101, Pogo; 102, Eden; and 103, Wilson.Table 1 lists the point identification number, the point name, the lithic material, and the quantity of the named points for each archaeological era for the Bolton points.

\section{Comments on the Population}

Figure 2 gives an indication of the habitation density in Camp County during the various archaeological periods. It is obvious that population density, as measured by dart point quantity, increased during the Late Archaic and Woodland periods.

Figures 3 and 4 compare the frequency and the frequency per century of dart point types from the Buddy Jones collection from the middle Sabine River basin counties with those of the Bolton collection. They are much the same, especially as shown by the points per century by period. The Jones collection point frequencies are from Perttula and Young (2012:37).

Thurmond (1990) analyzed 1712 dart points from the Cypress Creek watershed in Franklin, Camp, Titus, Upshur, and Marion counties. The dart points were from 14 archaeological sites within these counties. Thurmond's analysis shows the same trend regarding the frequency of dart points as do the Jones and Bolton collections from the Paleoindian through the Late Archaic periods. The Thurmond analysis could not be directly compared with the other two collections, however, as Thurmond used slightly different time spans for some of the Archaic periods, as well as some differences in how dart points were dated. The points of the Woodland period today were included in Thurmond's Late Archaic period.

\section{The Population Change Through Time}

Perttula (2013:37, n.d.:2) believes that major climatic changes in the region, particularly temperature and precipitation, were the major factors that influenced the number of aboriginal people living in Northeast Texas. Collins et al. (2011) established patterns of climate change (wet or dry periods), and bison absence or abundance, for Central Texas that probably carried over into East Texas as well. This climatic calendar extended from the Paleoindian through the Woodland periods. By the beginning of the Late Archaic period (5000 B.P.), after 5000 years of dry conditions (during most of the Early and Middle Archaic), a wet period began. Forest and prairie regions were much as they are today. Thus, food resources were enhanced and more predictable and conducive to a growing population (Perttula (2012:32). This is reflected in Figures 2-4 by the increase in dart points in the Late Archaic that carries over into the Woodland period. 


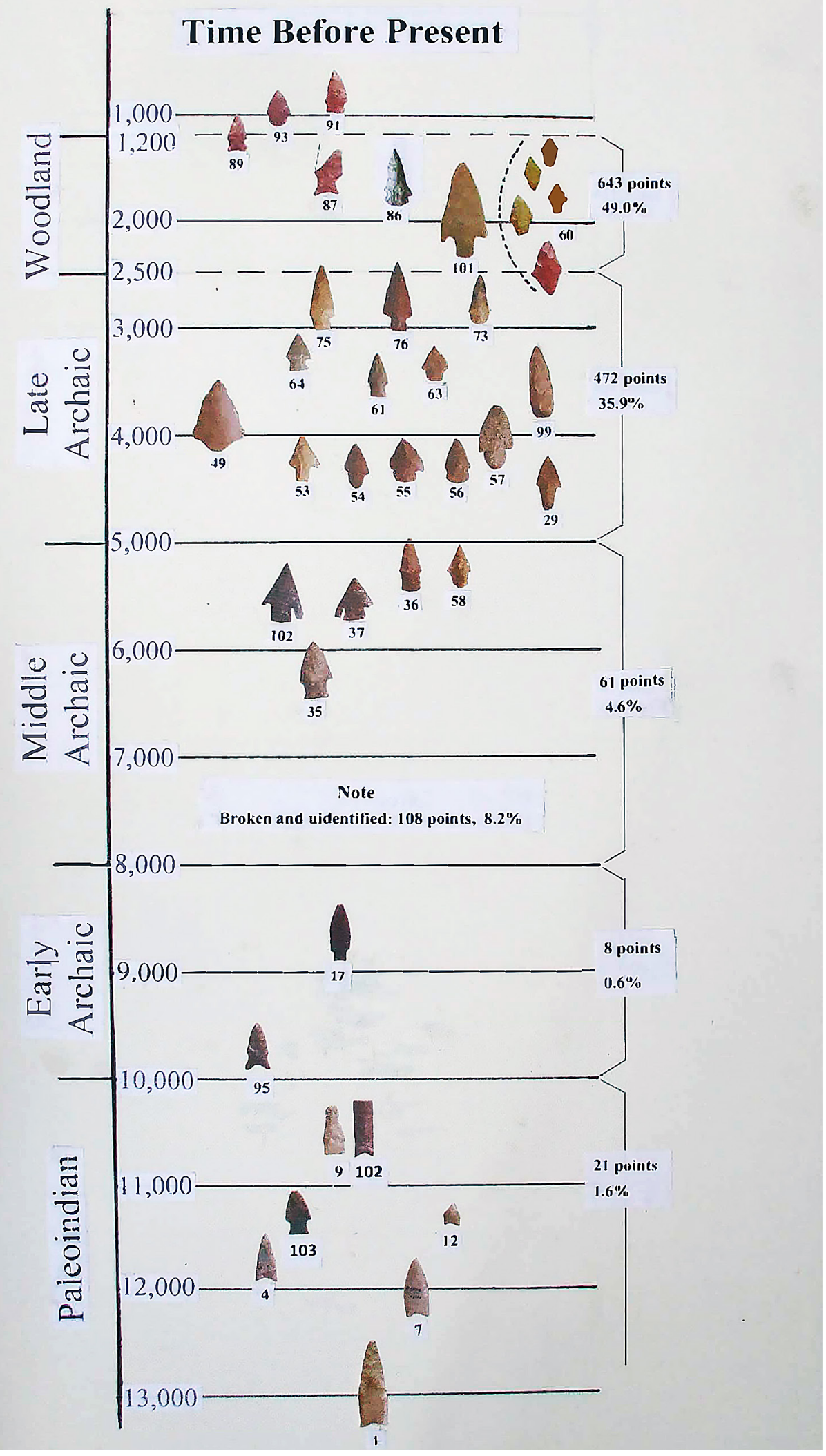

Figure 2. Temporal ordering of the Bolton Collection dart and spear point types. 
Table 1. Dart and spear points from the Bolton Collection.

The Woodland Period: 1200-2500 B.P.

\begin{tabular}{llllllllll}
\hline Point Number & Name & 1 & 2 & 3 & 4 & 5 & 6 & $\mathrm{~N}$ & Percent \\
91 & Darl & - & - & - & - & 2 & 1 & 3 & 0.5 \\
89 & Edgewood & 20 & - & 1 & 9 & - & 7 & 37 & 5.8 \\
93 & Elam & 3 & - & 3 & 4 & - & - & 10 & 1.6 \\
86 & Ensor & 1 & - & - & - & - & 1 & 2 & 0.3 \\
87 & Fairland & - & - & - & - & - & 1 & 1 & 0.2 \\
60 & Gary & 368 & 1 & 59 & 60 & 2 & 79 & 569 & 88.6 \\
101 & Pogo & - & - & - & 4 & 11 & 2 & 17 & 2.6 \\
& UID Spear & - & - & - & - & 2 & 2 & 4 & 0.6 \\
\cline { 2 - 8 } & Total & 392 & 1 & 63 & 77 & 17 & 93 & \multirow{2}{*}{643} & \\
& Lithics \% & 61.0 & 0.2 & 9.8 & 12.0 & 2.6 & 14.5 & & \\
\hline
\end{tabular}

Late Archaic Period: $2500-5000$ B.P.

\begin{tabular}{llllllllll}
\hline Point Number & Name & 1 & 2 & 3 & 4 & 5 & 6 & $\mathrm{~N}$ & Percent \\
\hline 49 & Almagre & - & - & - & - & 1 & - & 1 & 0.2 \\
57 & Axtell & 17 & - & - & 1 & - & - & 18 & 3.8 \\
53 & Bulverde & 2 & - & 2 & 7 & 16 & 8 & 35 & 7.4 \\
54 & Carrollton & 5 & $1^{*}$ & - & 1 & - & 1 & 8 & 1.7 \\
64 & Ellis & 14 & - & 6 & 5 & 5 & 5 & 35 & 7.4 \\
75 & Epps & - & - & - & - & - & 2 & 2 & 0.4 \\
73 & Godley & 5 & - & - & 3 & 2 & - & 10 & 2.1 \\
99 & Hill & 19 & $1 / 1^{* *}$ & 3 & 3 & 1 & 2 & 30 & 6.4 \\
63 & Kent & 19 & 1 & 6 & 8 & 4 & 22 & 60 & 12.9 \\
76 & Motley & - & 1 & - & - & - & - & 1 & 0.2 \\
62 & Pontchartrain - & - & - & - & - & 2 & 2 & 0.4 \\
56 & Trinity & 18 & $1 *$ & 1 & 1 & 6 & 3 & 30 & 6.4 \\
29 & Wells & 40 & - & 1 & 1 & - & 12 & 54 & 11.4 \\
55 & Williams & 6 & - & - & - & - & 2 & 8 & 1.7 \\
61 & Yarbrough & 137 & - & 8 & 8 & 6 & 25 & 184 & 38.8 \\
& Total & 282 & 6 & 27 & 38 & 34 & 85 & 472 & \\
& Lithics $\%$ & 59.7 & 1.2 & 5.7 & 8.0 & 7.2 & 19.0 & & \\
\hline
\end{tabular}

*hematite; **ferruginous sandstone; $1=$ local quartzite; $2=$ petrified wood; $3=$ jasper; $4=$ novaculite; $5=$ Central Texas chert; $6=$ non-local chert 
Table 1. Dart and spear points from the Bolton Collection, cont.

Middle Archaic Period: 5000-8000 B.P.

\begin{tabular}{llllllllll}
\hline Point & & & & & & & & & \\
Number & Name & 1 & 2 & 3 & 4 & 5 & 6 & $\mathrm{~N}$ & Percent \\
$37-38$ & Bell-Andice & - & - & - & - & 8 & - & 8 & 13.1 \\
100 & Calf-Creek & - & - & 1 & 7 & - & - & 8 & 13.1 \\
58 & Evans & - & - & 1 & - & - & - & 1 & 1.6 \\
35 & Johnson & 4 & - & - & - & - & 3 & 7 & 11.5 \\
36 & Morrill & 26 & - & 2 & 2 & 2 & 5 & 37 & 60.7 \\
\cline { 2 - 9 } & Total & 30 & - & 4 & 9 & 10 & 8 & 61 & \\
& Lithics \% & 49.2 & - & 6.6 & 14.8 & 16.4 & 13.1 & & \\
\hline & & & & & & & & & \\
\end{tabular}

Early Archaic Period: 8000-10,000 B.P.

\begin{tabular}{llllllllll}
\hline Point Number & Name & 1 & 2 & 3 & 4 & 5 & 6 & N & Percent \\
\hline 95 & Breckenridge - & - & - & - & 1 & 6 & 7 & 87 \\
17 & Hoxie & - & - & - & - & - & 1 & 1 & 13 \\
\cline { 2 - 8 } & Total & & & & & 1 & 7 & 8 & \\
& Lithics \% & - & - & - & - & 13 & 87 & & \\
\hline
\end{tabular}

Paleoindian Period: Before 10,000 B.P.

\begin{tabular}{llllllllll}
\hline Point Number & Name & 1 & 2 & 3 & 4 & 5 & 6 & $\mathrm{~N}$ & Percent \\
\hline 1 & Clovis & - & - & - & - & 1 & - & 1 & 4.7 \\
4 & Dalton & - & - & - & - & 1 & 4 & 5 & 23.8 \\
102 & Eden & - & - & - & - & - & 1 & 1 & 4.7 \\
7 & Plainview & - & - & - & - & 8 & 1 & 9 & 42.6 \\
12 & San Patrice & - & - & - & 1 & - & - & 1 & 4.7 \\
9 & Scottsbluff & - & - & - & - & 2 & 1 & 3 & 14.3 \\
103 & Wilson & - & - & - & - & 1 & - & 1 & 4.7 \\
\cline { 2 - 8 } & Total & - & - & - & 1 & 13 & 7 & 21 & \\
& Lithics \% & & & & 4.7 & 61.9 & 33.3 & &
\end{tabular}

UID=unidentified; $1=$ local quartzite; $2=$ petrified wood; $3=$ jasper; $4=$ novaculite $;=$ Central Texas chert; $6=$ non-local chert 


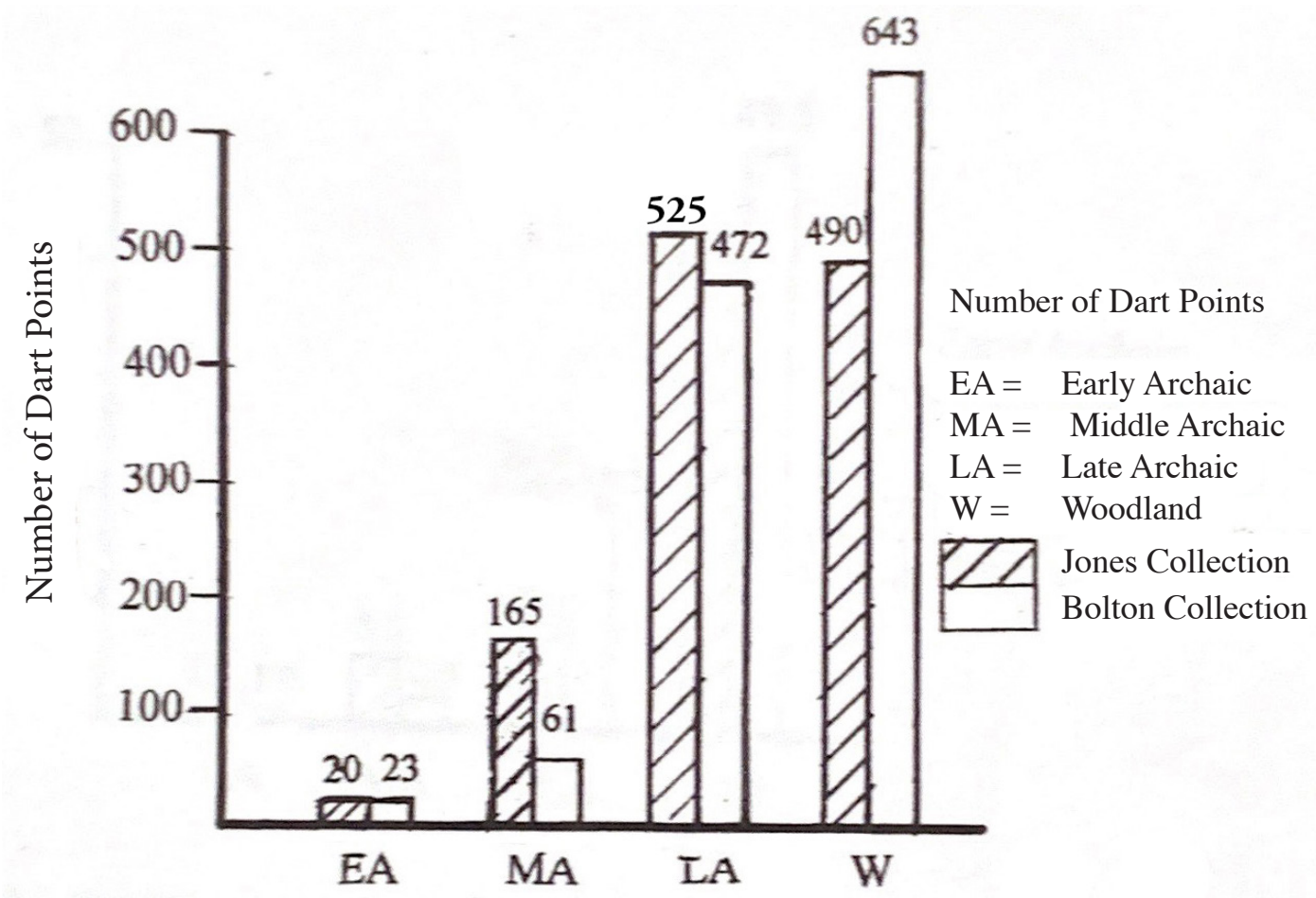

Figure 3. Comparison of dart points from the Jones and Bolton collections by time periods.

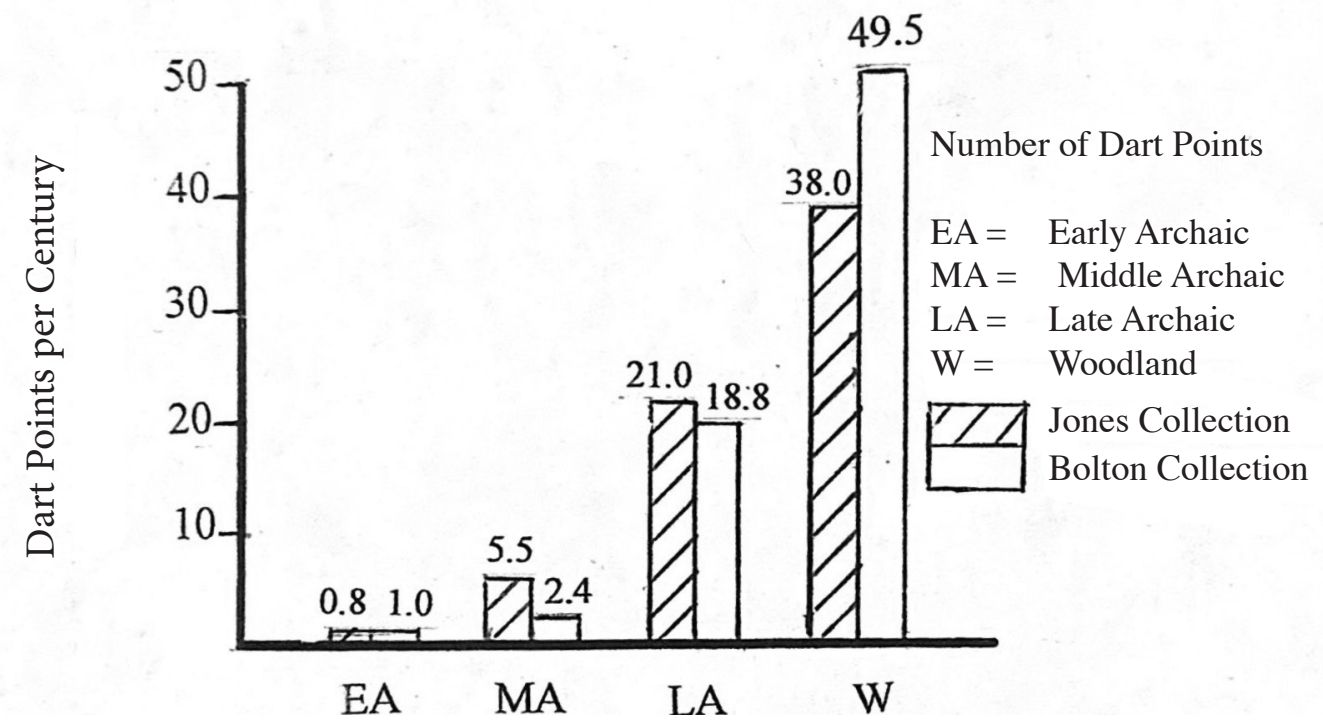

Figure 4. Dart points per century in the Archaic and Woodland periods.

\section{The Dart Point Lithic Materials}

Table 1 also enumerates the lithic raw material used for each variety of dart point. These six raw material types are quartzite, petrified wood, jasper, novaculite, Central Texas chert, and non-local unidentified chert. The first three types are of local origin, while the last three are from foreign sources. The identified non-local cherts are from the Central Texas Edwards Plateau and Ouachita Mountain sources. Perttula and Miller (2014) provide a more detailed description of the sources of these lithic materials. 
The local lithic materials (quartzite, petrified wood, and jasper) are plentiful in Camp County and Northeast Texas. They are found both in stream beds and in upland areas. The local quartzite may be found in both cobble and pebble size and is the most abundant of these local materials. The jasper and most petrified wood are in pebble size.

Nelson (in Perttula and Miller 2014) made a reconnaissance near the Kitchen Branch (41CP220) and Keering (41CP21) sites in southeastern and south-central Camp County in the Prairie Creek drainage basin. Nelson found nine areas near these two sites where knappable material was present on the surface. Each area contained quartzite cobbles and pebbles of both fine and coarse-grained material. Petrified wood pebbles were present in five of these areas and jasper pebbles in four of them. These deposits are believed to have been derived from formations in the Ouachita Mountains of southeastern Oklahoma (Banks 1990). The jasper pebble colors were yellowish-brown, gray, red, light brown, brown, greenishbrown, and reddish-brown, a wide spectrum of colors related to iron oxides. A local flint knapper would know numerous places where suitable chert was available.

In order to separate the six raw material types of the points within the Bolton Collection (see Table 1 and Appendix 1), ultra-violet inspections were used. The first ultraviolet source used was a "black light"-emitting bulb acquired at Walmart. In this article, "black light" refers only to this source. The ultraviolet wave length or frequency was not recorded on the packaging. The second ultraviolet source used provided a $365 \mathrm{~nm}$ wave length.

If the origin of the raw materials is known, it provides a clue to the origin of the people that brought the particular dart point to Camp County, or where the local inhabitants acquired it and manufactured it, or both. Local raw materials and points are fine and coarse-grained quartzite, petrified wood, and jasper, with an occasional point of hematite or ferruginous sandstone; ferruginous sandstone has the basic appearance of the original material from which it was chipped, while hematite is weathered into layers (see Turner 2006).

The novaculite listed in Table 1 is all translucent. This translucence ranges from 20-100 percent of the point. The source of these points, or the raw material, is the Ouachita Mountains of Oklahoma or Arkansas as well as gravels in the Red River.

The Central Texas chert was confirmed using the $365 \mathrm{~nm}$ ultraviolet light inspection. To muddy the waters, however, the Central Texas chert is not the only chert that fluoresces at this wave length. Most of the translucent novaculite points fluoresce a white-yellow color as did the Central Texas points.

The sixth raw material listed as a "non-local" chert also has a significant number of points that fluoresce. These points are all opaque. A comparison of the Gary novaculite translucent points and opaque non-local chert points have the same mix of colors. The colors range from tan to black, and multiple shades of gray to near-white. I conclude that many of the non-local points are also novaculite.

All lithic artifacts were inspected with the "black light" emitting source. As a basis for comparison of fluorescence of an artifact for color and brightness, a small clod of East Texas red clay was viewed under this "black light." If crumbled into sand, the same fluorescence is present. This is probably the basic color of the ferrous molecular structure that fluoresces. The color is a Chinese red-orange, especially when viewed in a dark room.

All points were examined under this light. All jasper points fluoresced with a reddish glow as did numerous quartzite points and a very few novaculite points and points of non-local chert. After separating the quartzite points into their types, and then into groups that glowed and those that did not, it was noted that those that glowed had a maroon cast, and some had a different flaking appearance from those with no glow. That is, the quartzite points that had acquired this fluorescence had been heat treated. 
Table 2 shows that from the Middle Archaic period through the Woodland period local people were heat treating at least some of their quartzite cobbles used for dart points. This heat treatment is indicated by the black light fluorescence of the quartzite points. Fluorescence of the jasper and quartzite pale when compared to the red clay dirt. However, jasper is brighter than quartzite.

Table 2. Fluorescence of quartzite dart points in the Bolton collection.

\begin{tabular}{|c|c|c|c|c|c|c|c|}
\hline & \multicolumn{3}{|c|}{ Woodland Period } & \multicolumn{4}{|c|}{$\underline{\text { Late Archaic Period }}$} \\
\hline & $\mathrm{N}$ & $\mathrm{NF}$ & $\%$ & & $\mathrm{~N}$ & NF & $\%$ \\
\hline Edgewood & 18 & 7 & 39 & Almagre & - & - & - \\
\hline Darl & - & - & - & Axtell & 17 & 4 & 24 \\
\hline Elam & 3 & - & - & Bulverde & 3 & 1 & 33 \\
\hline Ensor & 3 & 1 & 33 & Carrolton & 4 & 2 & 50 \\
\hline Fairland & - & - & - & Ellis & 15 & 6 & 4 \\
\hline Gary & 391 & 73 & 18.7 & Epps & - & - & - \\
\hline Pogo & - & - & - & Godley & 4 & 1 & 25 \\
\hline \multirow[t]{4}{*}{ UID Spear } & - & - & - & Hill & 18 & 9 & 50 \\
\hline & & & & Kent & 26 & 13 & 50 \\
\hline & \multicolumn{3}{|c|}{$\underline{\text { Middle Archaic Period }}$} & Motley & - & - & - \\
\hline & $\mathrm{N}$ & $\mathrm{NF}$ & $\%$ & Trinity & 18 & 9 & 50 \\
\hline Bell-Andice & - & - & & Wells & 41 & 11 & 27 \\
\hline Calf-Creek & - & - & - & Williams & 3 & 1 & 33 \\
\hline Evans & - & - & - & Yarbrough & & & \\
\hline Johnson & 4 & 1 & 25 & Dike & 32 & 6 & 19 \\
\hline \multirow[t]{2}{*}{ Morrill } & 29 & 8 & 28 & Maybank & 30 & 8 & 27 \\
\hline & & & & Lindale & 92 & 28 & 30 \\
\hline
\end{tabular}

$\mathrm{N}=$ number of points; $\mathrm{NF}=\mathrm{Number}$ that Fluoresce; $\%=$ percent that fluoresce

Table 3 lists the Gary points that did and did not fluoresce under the "black light." The points were separated to see if there were differences between the various varieties of Gary points in whether they were heat treated or non-heat treated. The Hobson variety points show less heat treatment, and the large Pana Maria variety showed more. The remaining varieties had percentages between these two. Approximately 18.4 percent of all quartzite Gary points were heat treated. Percentages of the other raw materials that fluoresced are listed as well.

The inspection with "black light" may be used to separate jasper from similar colored cherts. The fluorescence of the jasper is not caused by heat treating, as was the quartzite, but is inherent in the basic ferric molecular structure of the jasper.

\section{The Woodland Period (2500-1200 B.P.) Dart and Spear Points}

Schambach (2002) defined a Woodland period Fourche Maline culture in the Ouachita Mountains of southeast Oklahoma, while in Arkansas, it covers the southwestern quarter of the state, south of the 
Table 3. Gary points in the Bolton Collection that fluoresce under black light.

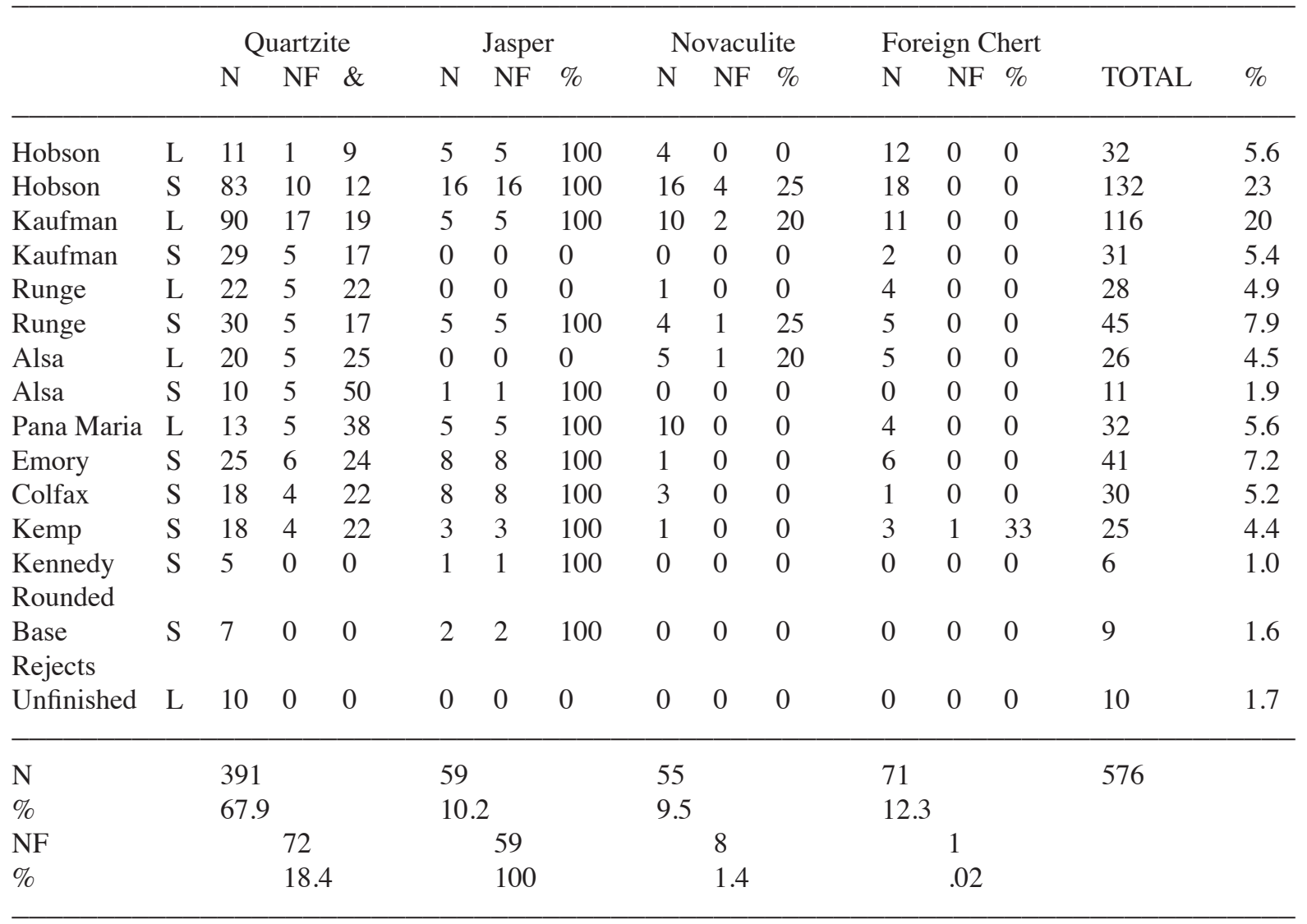

$\mathrm{L}=$ Points $=$ or $>40 \mathrm{~mm}$ length; $\mathrm{S}=$ Points $<40 \mathrm{~mm}$ length; $\mathrm{N}=$ Total number of points; NF=Number that Fluoresce; $*$ One Runge L of petrified wood did not Fluoresce; **The fluorescence of the Quartzite points results from heat treatment

Arkansas River. The northwestern part of Louisiana is part of the Fourche Maline region as well. In Texas, Fourche Maline sites occur in the Pineywoods of Northeast Texas, from the Sabine River drainage northward to the Red River and westward into the Post Oak Savanna.

The artifacts associated with the Fourche Maline culture are plain ware pottery, Gary dart points of several varieties (Figure 5), double bitted "axes," boatstones, clay platform pipes, and seed and nut processing equipment (Schambach 2002). Selected artifacts of the Bolton collection are indicative of the Fourche Maline culture. No platform pipes, plain pottery, or stone seed or nut grinding implements were in the collection, however. I have collected platform pipes and over 120 grinding implements from Camp County sites, however, and pottery sherds I collected are associated with specific Woodland sites (Perttula 2014:43). To the south of the Texas Fourche Maline culture area were Mossy Grove and Mill Creek cultures (Shafer and Walters 2010). For a description of the ceramics of these contemporary Woodland groups, see Ellis (2013).

Other sites in Northeast Texas with a Fourche Maline component, or that have a pure Fourche Maline occupation, are the Stallings Ranch site on Pine Creek in Lamar County, the Manton Miller site, the Tankersley Creek site, and the Yarbrough site. These sites (see Figure 1) are all near Camp County but are within the Post Oak Savanna region. Within Camp County, the Horton site and the Lizzie Hill site (which have Woodland components) are described by Perttula (2014:43). The dart points from these sites and those of the Bolton collection are quite similar. 


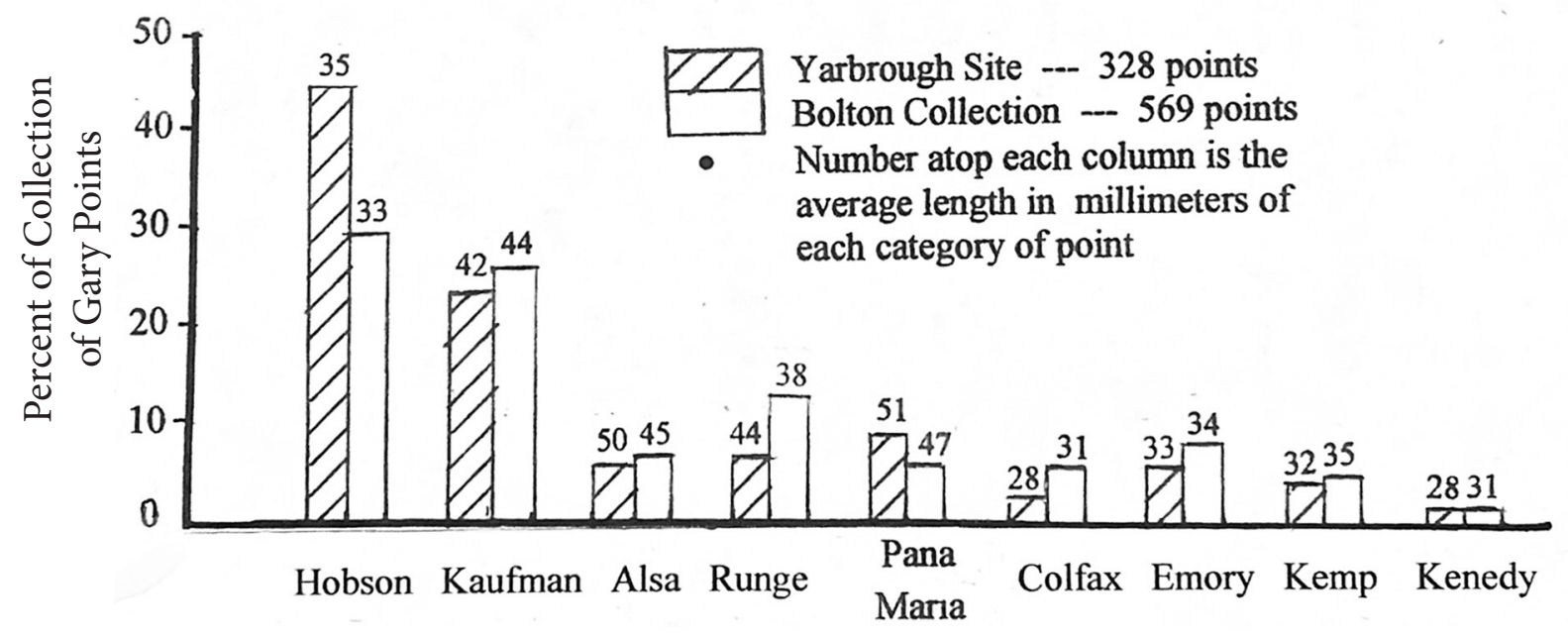

Figure 5. A graphic comparison between the Gary points of the Yarbrough and Bolton collections.

Figure 6 pictures Gary, variety Kaufman points in the upper two rows and variety Hobson in the lower two. In Figure 7, the four rows, top to bottom, are Gary, varieties Runge, Alsa, Pana Maria, and Colfax. From top to bottom, variety Emory, Kemp, Kennedy, and an unnamed variety with rounded stem base are illustrated in Figure 8. These varieties were named by Johnson (1961), except the rounded base points. The variety Emory points may be identified because the tips of their contracting stems have been flattened by flaking.

Schambach (1982: 173-177) divided the Gary point type of Southwestern Arkansas into three varieties instead of the nine varieties Johnson proposed using the points from the Yarbrough site. Schambach's three varieties were var. Gary, var. LeFlore, and var. Camden He stated that the prime diagnostic feature of var. Gary is a broad lobate stem, convex edges, and a rounded base. He provided maximum and minimum dimensions of this variety as length $3.4-7.9 \mathrm{~cm}$, width $2.2-5.0 \mathrm{~cm}$, thickness of 0.6-1.3 cm, stem length $1.1-2.9 \mathrm{~cm}$, and stem width at shoulder of $1.7-2.8 \mathrm{~cm}$. These dimensions were from 83 points from three sites. He believed this variety comes from the very early or transitional Fourche Maline components or in preceramic contexts. He considers this the ancestral archaic variety of the Gary type.

Schambach's second variety, var. LeFlore, has stems narrower in proportion to the blades than var. Gary and the stems are V-shaped with pointed bases rather than lobate with rounded bases. Leflore points are about $0.3 \mathrm{~cm}$ thinner than var. Gary. Dimensions of most of the var. LeFlore are length, $4.5-5.1 \mathrm{~cm}$, width 2.8-3.0 cm, thickness $0.7-0.8 \mathrm{~cm}$, stem length $1.3-1.5 \mathrm{~cm}$, and a stem width at the shoulder of 1.6$1.7 \mathrm{~cm}$. A sample of 500 points from three sites was used to define this category. Schambach believes this is an early Fourche Maline marker variety.

The third Gary variety, var. Camden, was defined from a sample of 420 points from three sites. These are the narrowest of the three Gary varieties. Camden points have lengths between 2.9-8.8 cm, and most points have a width of 2.0-2.1, a thickness of $0.7 \mathrm{~cm}$, a stem length of $1.2-1.5 \mathrm{~cm}$, and a stem width at the shoulder of $1.3-1.5 \mathrm{~cm}$.

Schambach noted that there is an apparent but unverified trend toward a higher percentage of shoulder-less or weekly shouldered points in late Fourche Maline components, suggesting a possible new variety. The variety Hobson defined by Johnson seem to fit this nicely. They not only are weakly shouldered but their stems are usually 40-50 percent or more of their length (see Figure 6). 


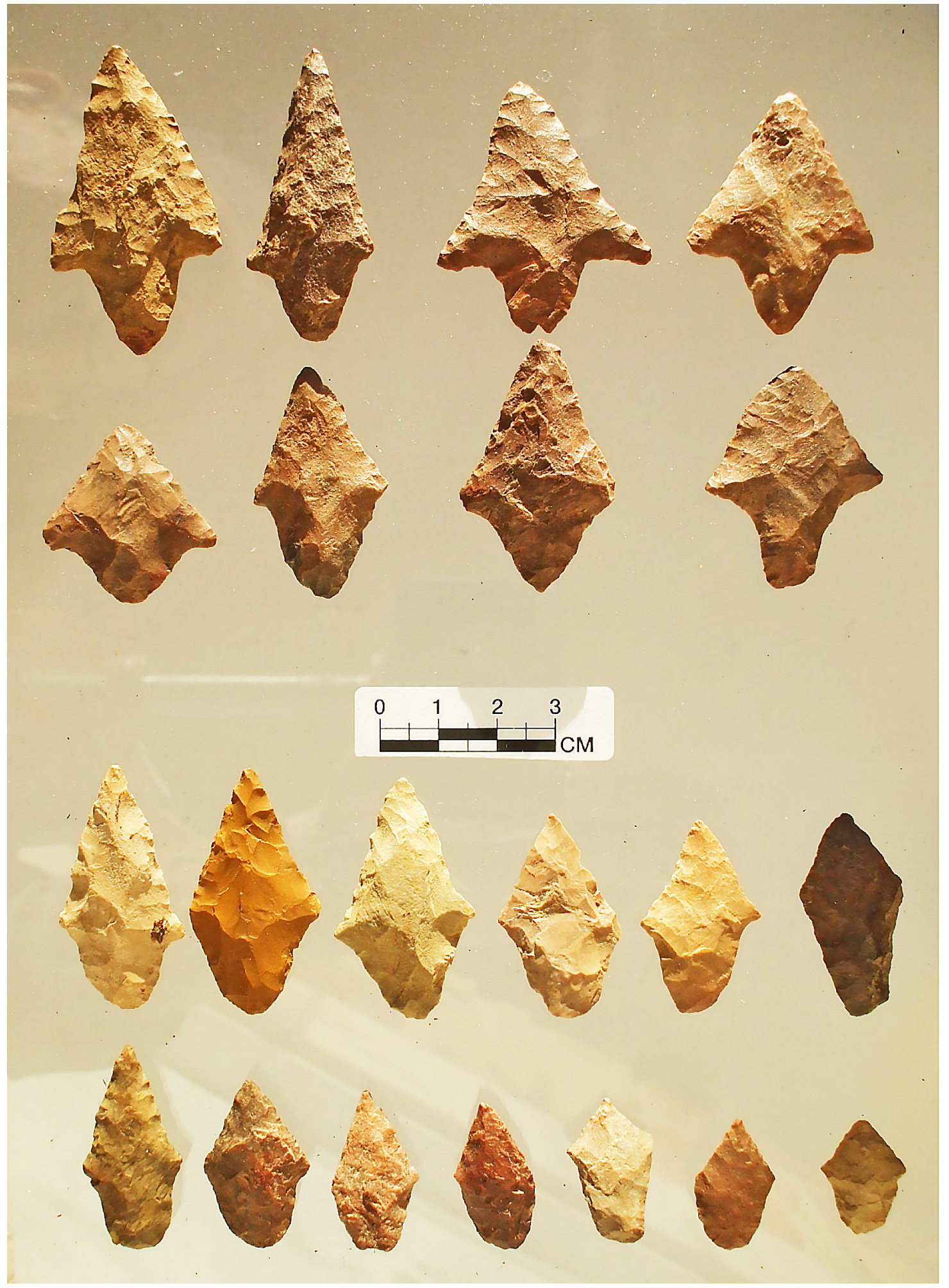

Figure 6. Gary points: variety Kaufman, top two rows; variety Hobson, bottom two rows. 


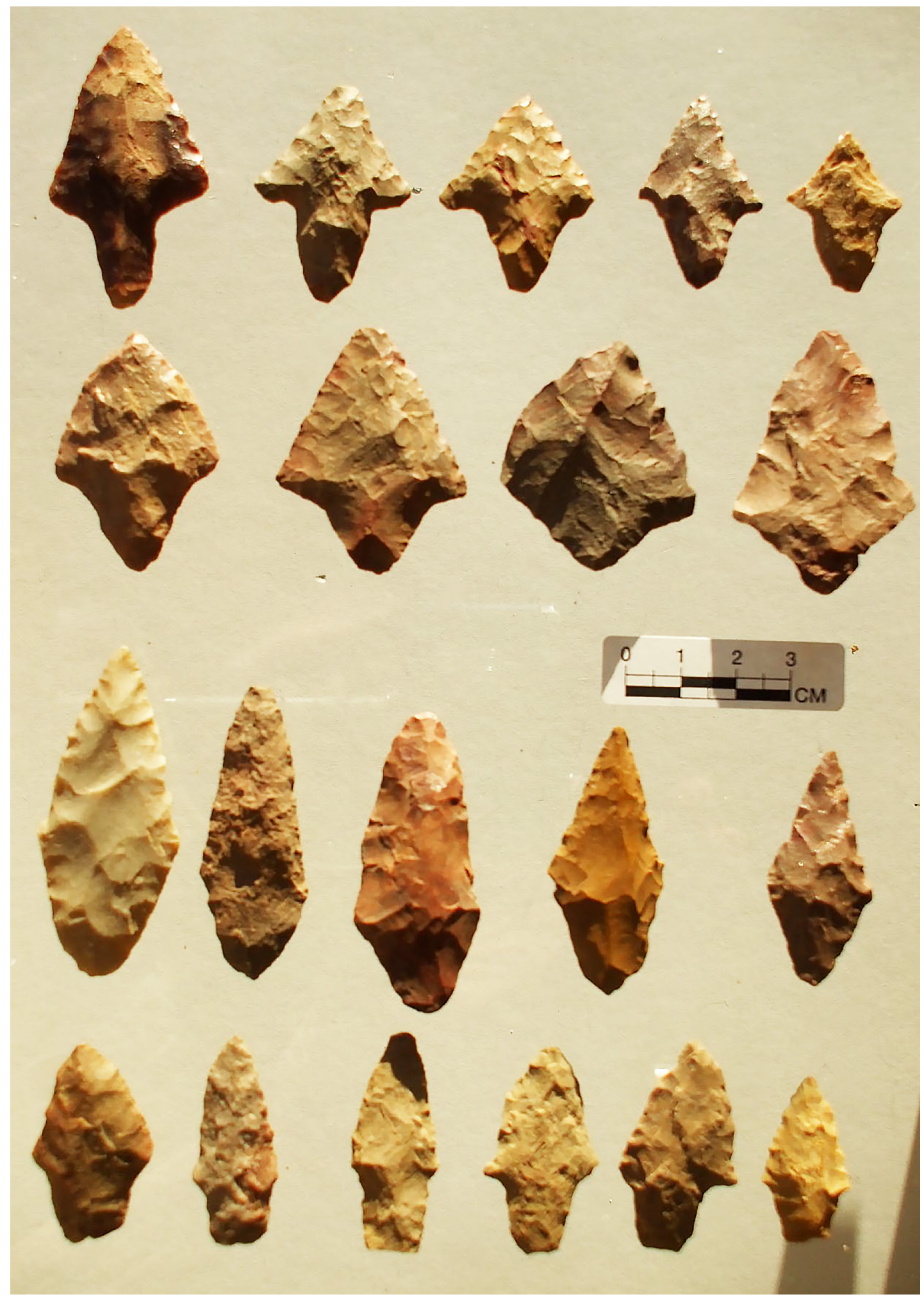

Figure 7. Gary points, top to bottom rows, varieties Runge, Alsa, Pana Maria, and Colfax. 


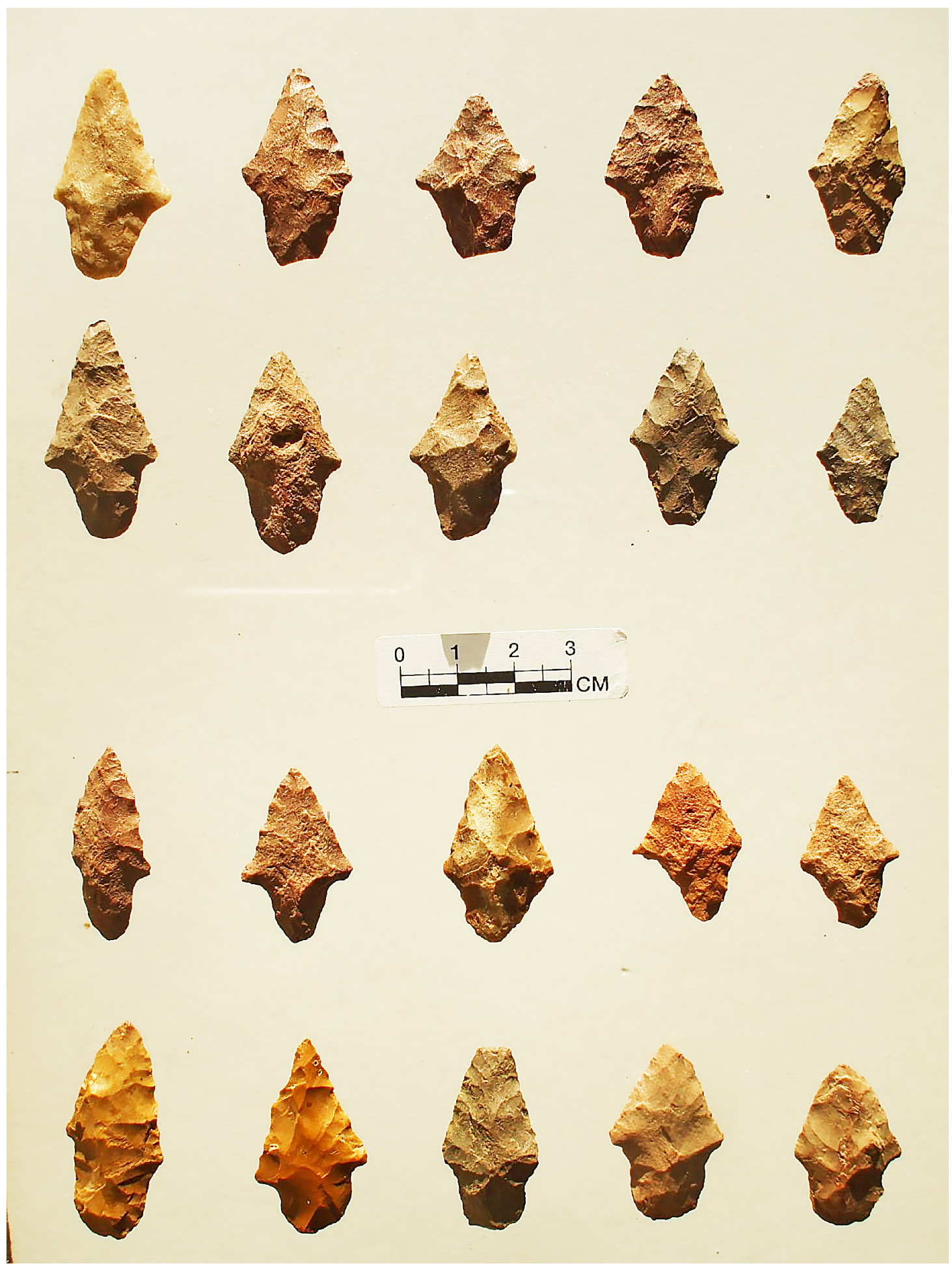

Figure 8. Gary points: top to bottom varieties Emory, Kemp, Kennedy, and an unnamed variety with a rounded stem. 
The Bolton collection Gary points were classified the same as the Yarbrough site points by Johnson. This provides a better comparison between sites in this article. If the Bolton collection points were reclassified using the Schambach varieties, the varieties Kaufman, Alsa, and Pana Maria would be placed in the var. Gary, with the Runge, Kemp, and Kennedy in var. LeFlore, and Colfax and Emory in the var. Camden. The Hobson variety defined by Johnson does not fit a named variety in Schambach's nomenclature.

The stratigraphic location of Gary points at both the Yarbrough and Tankersley Creek sites position the larger points in the lower stratigraphic levels and the smaller points at the higher levels. There is a mix of sizes in the mid-levels. Thus, it is apparent the indigenous people gradually replaced their larger points with the smaller Gary points while sometimes keeping the shape of the larger. The size and weight of the smaller Gary points would certainly permit their use as arrow points.

Dr. Ed Jelks, personal communication, many years ago, divided dart and arrow point analysts into two categories, that is, lumpers and splitters. I believe Schambach and Johnson exemplify these types.

Figure 9 pictures the remaining dart points of the Woodland period group in the Bolton collection. The top row is Edgewood, the second row has Elam points, and the third row has Ensor, Fairland, and two Darl points. The points on the bottom row are not attributed to local manufacture, but are likely the product of wandering hunters or adventurers from Central Texas.

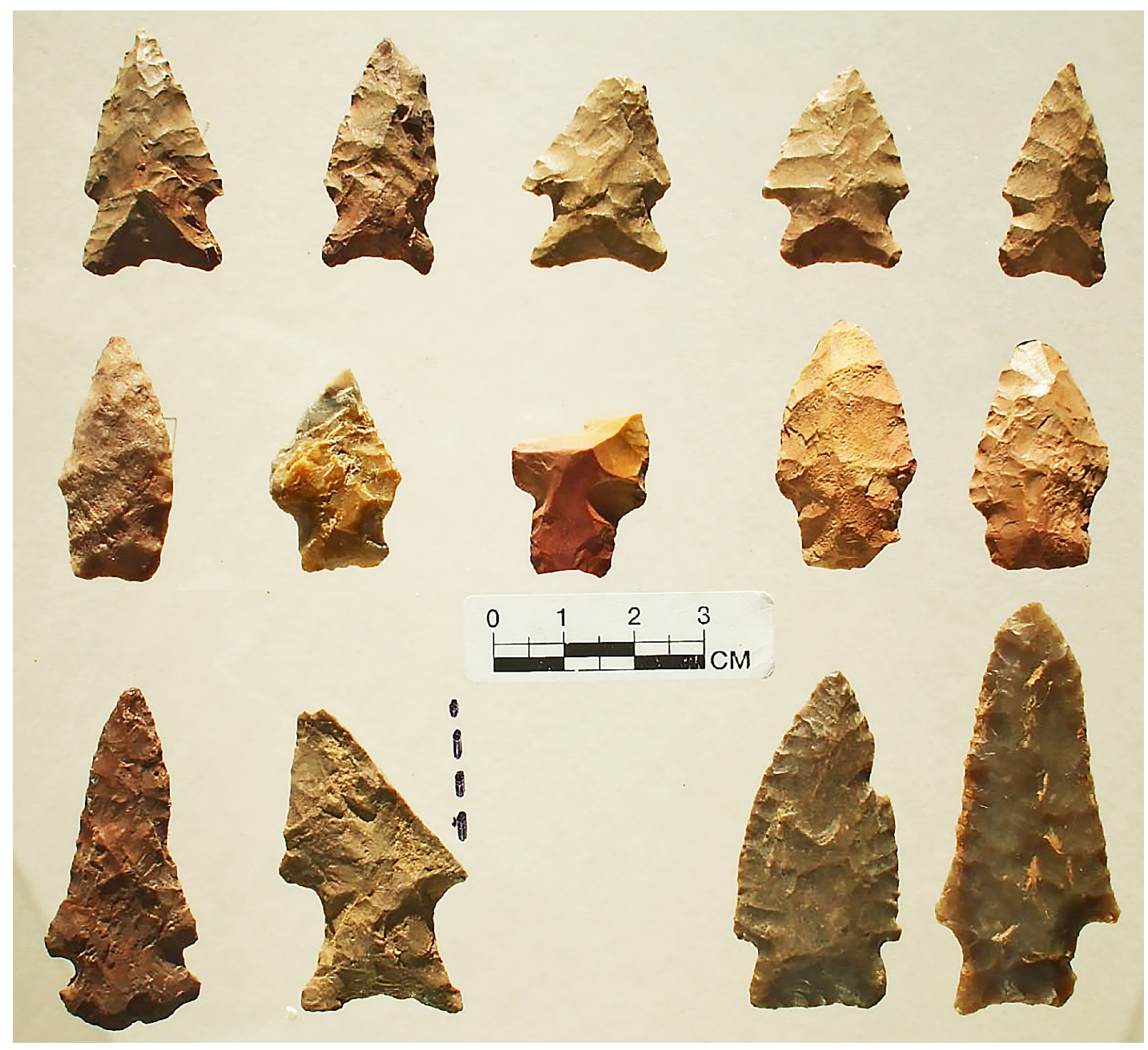

Figure 9. Top row Edgewood, middle row Elam, bottom row, left to right, Ensor, Fairland, and two Darl points. 
Also included in the Woodland period assemblage are spear points. All 20 of the points are pictured in Figures 10-12, and Table 4 lists them by identification number, type, raw material, and major dimensions. The spear points never appear in post-A.D. 800 ancestral Caddo graves.

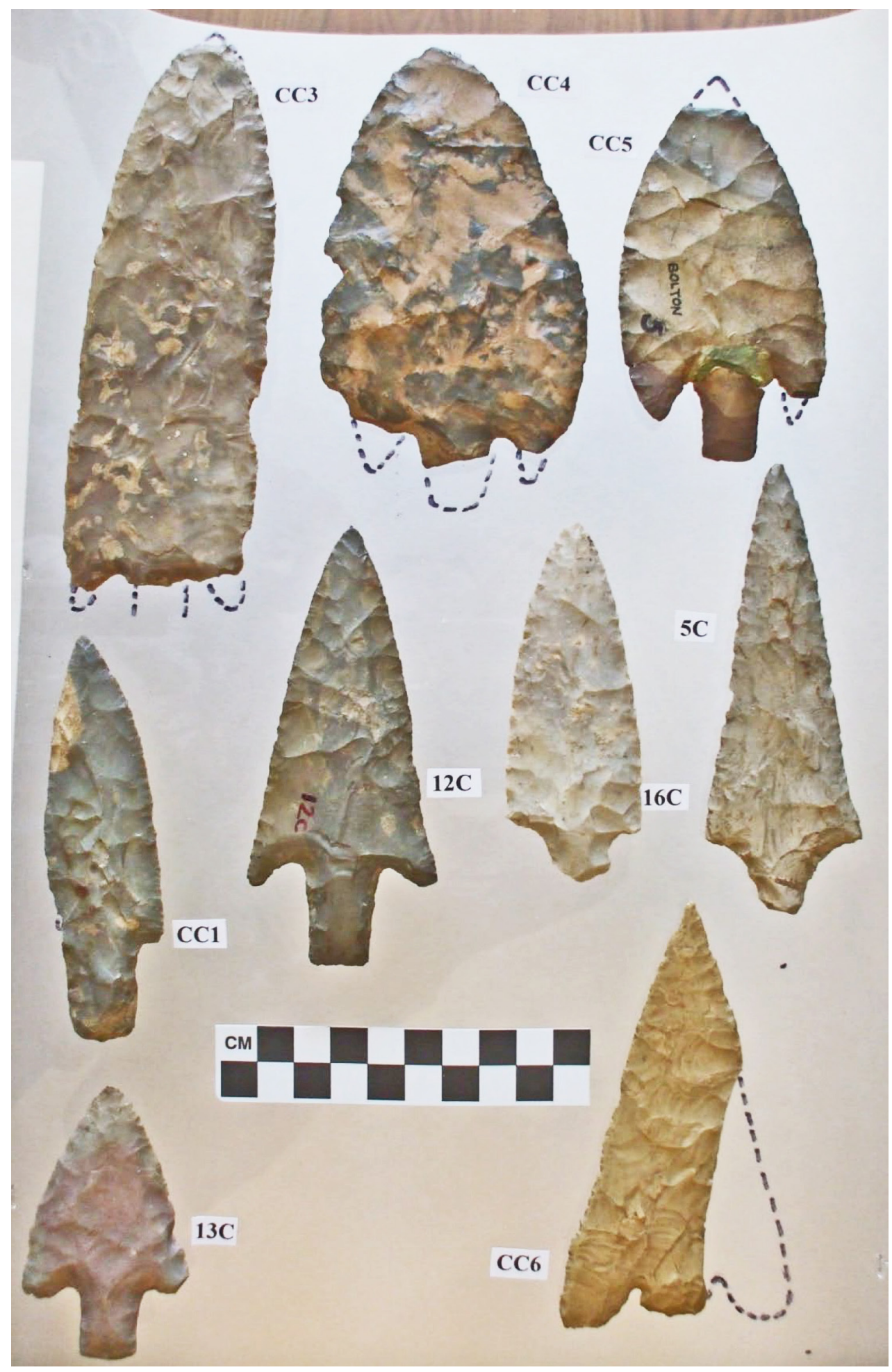

Figure 10. Spear points from the Bolton Collection. 


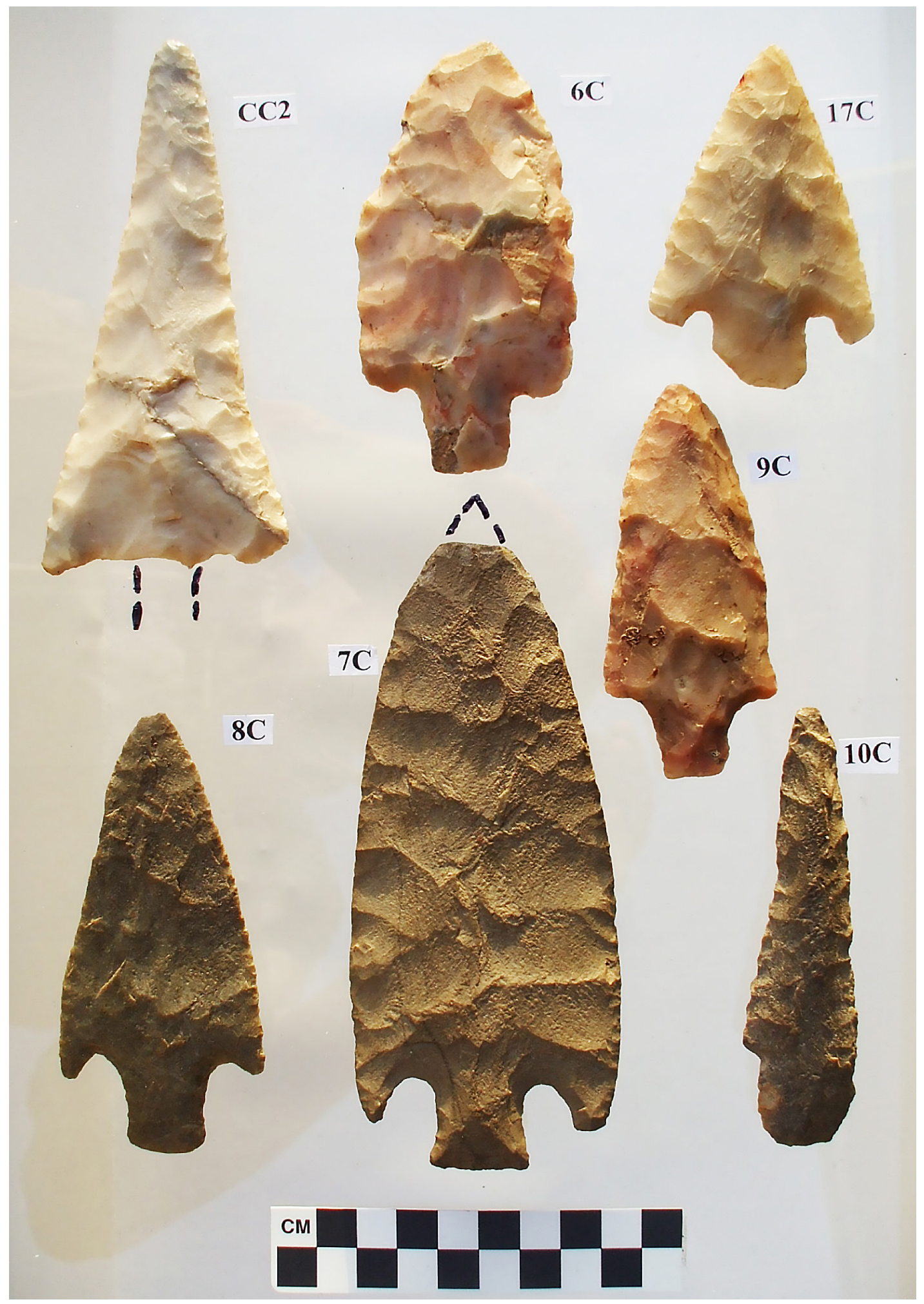

Figure 11. Other spear points from the Bolton Collection. 


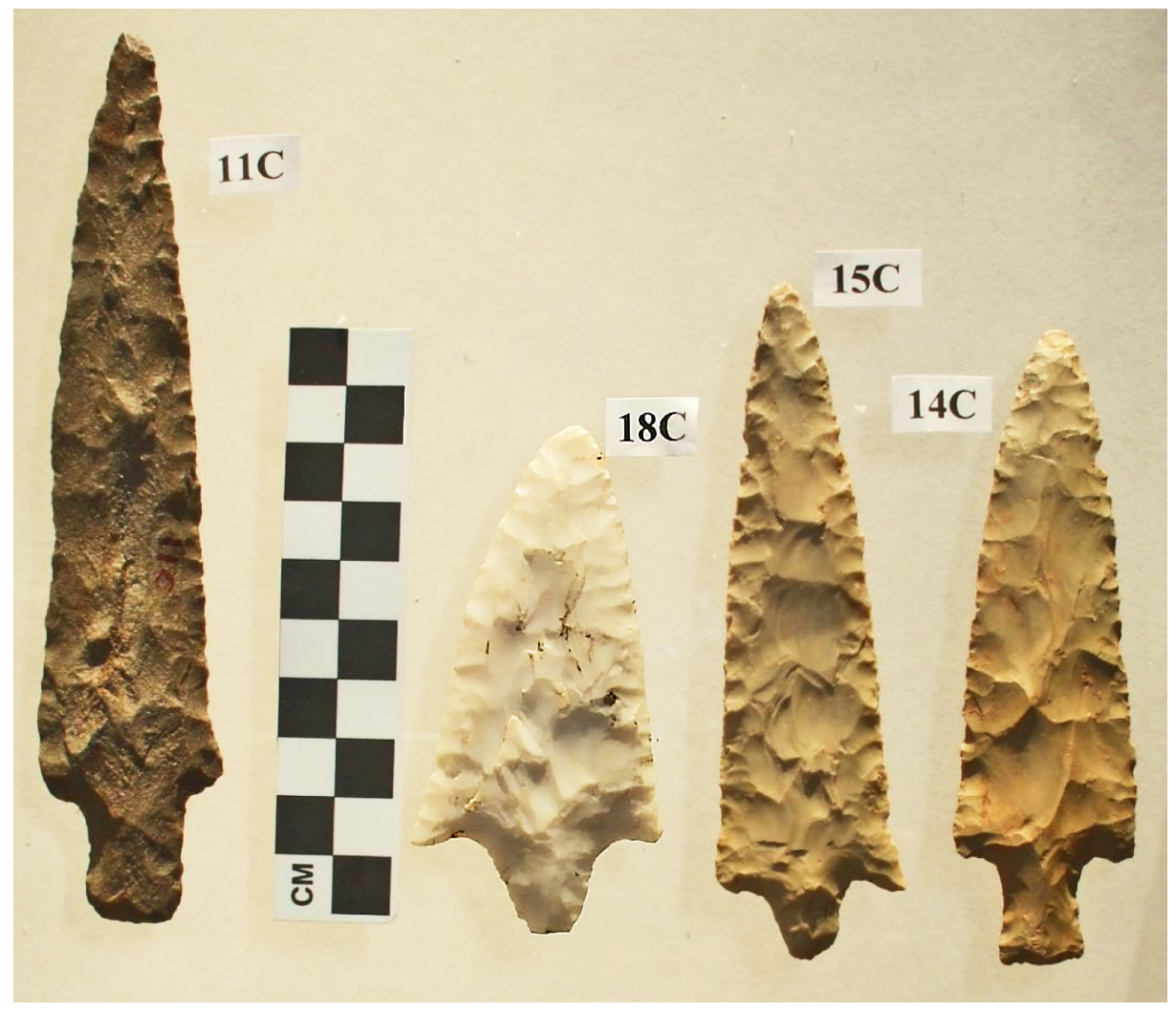

Figure 12. Additional spear points from the Bolton Collection.

Table 4. Spear points in the Bolton Collection.

\begin{tabular}{rlllll}
\hline I.D. & Type & Lithic Identification & Length & Width & Thickness \\
\hline 5C & Pogo & Central Texas Chert & 122 & 42 & 10 \\
6C & Pogo & Novaculite & 110 & 53 & 15 \\
7C & Pogo & Jackfork Chert & 158 & 66 & 10 \\
8C & Pogo & Jackfork Chert & 109 & 61 & 9 \\
9C & Pogo & Novaculite & 96 & 41 & 13 \\
10C & Unknown & Jackfork Chert & 109 & 27 & 11 \\
11C & Unknown & Jackfork Chert & 152 & 31 & 11 \\
12C & Pogo & Central Texas Chert & 118 & 50 & 10 \\
13C & Pogo & Central Texas Chert & 73 & 46 & 9 \\
14C & Pogo & Central Texas Chert & 108 & 32 & 11 \\
15C & Pogo & Central Texas Chert & 113 & 31 & 6 \\
16C & Pogo & Central Texas Chert & 96 & 36 & 9 \\
17C & Pogo & Novaculite & 88 & 54 & 7 \\
18C & Pog & Novaculite & 86 & 43 & 11 \\
CC1 & Pogo & Central Texas Chert & 111 & 31 & 13 \\
CC2 & Pogo & Novaculite & 134 & 61 & 9 \\
CC3 & Pogo & Central Texas Chert & 155 & 54 & 11 \\
CC4 & Pogo & Central Texas Chert & 119 & 72 & 10 \\
CC5 & Pogo & Central Texas Chert & 99 & 55 & 6 \\
CC6 & Unknown & Central Texas Chert & 119 & 62 & \\
\hline
\end{tabular}

Note: Dimensions are in millimeters 
Spear points are not often described in the literature of East Texas archaeology. Suhm and Krieger (1954) described and pictured spear points identified as Pogo points. Pogo points were also included in the Handbook of Texas Archeology: Type Descriptions (Suhm and Jelks 1962). In these references, it is noted that many of the specimens are made of novaculite as well as ferruginous sandstone and chert. The nearest novaculite sources to Camp County are the Ouachita Mountains of southeastern Oklahoma and western Arkansas as well as Red River gravels.

Of the 20 spear points in the Bolton collection, 11 are made from Central Texas chert, five are made of novaculite, and four are a dark gray Jackfork quartzitic sandstone. Jackfork materials occurs across the entire Ouachita Mountains chain and is at least $130 \mathrm{~km}$ distance from Camp County, except for these materials that may be found in Red River gravels. Seventeen of the 20 points fit the shape and size of the Pogo type illustrated in Suhm and Krieger (1954). Two of the Jackfork quartzitic sandstone points are long and slender and do not fit the Pogo category. One point, identification number CC6 (see Figure 10, lower right), is an extremely thin and well-made point of unknown type.

During the 1950s and 1960s I surface collected over 1400 dart points from four sites in Camp County with major Late Archaic and Woodland components. No spear points were found. The only two spear points I found were in the 1930s in Nacogdoches County. Most of the archaeological sites in East Texas are on landforms that have long been in cultivation. In Camp County, during the 1930s and early 1940s, when the Bolton collection was assembled, cultivation had been in progress for 70 or 80 years. Before World War II, most plowing was done with one or two mules pulling a Georgia stock or turning plow. Thus, the plowman was close to the soil being turned and large spear points could be seen, picked up, and brought home. Smaller dart points may not have been seen, or if they were, it may not have been worthwhile to stop the mules to collect them. I propose that the farm boys that brought spear points to Mr. Bolton in the 1930s could have brought them from a home collection.

\section{The Late Archaic (ca. 5000-2500 B.P.) Period Dart Points}

Figure 13 pictures Late Archaic points of the Bolton collection. Point A is an Almagre point, more at home in Val Verde County to the south and west of Central Texas, according to Suhm and Jelks (1962). Points B-D are classified as Axtell points, found from Central to East Texas. The Axtell points in the Bolton collection are nearly exclusively made of local quartzite.

Points E-I in Figure 13 are Bulverde, predominantly a Central Texas point. Several Bulverde points in the collection, other than the 16 of Central Texas chert, are of local quartzite, jasper, and novaculite, as well as on an unidentified non-local chert (see Table 1). Points J-N are Carrollton, generally a North Central Texas to East Texas point type. Points O-S are Ellis points, found in the same area as the Carrollton type. As 20 of the 35 Ellis points are of Camp County raw materials, they were likely fabricated by the indigenous peoples.

Figure 14 pictures Hill points, a new type I have identified. Perttula (2014:43) illustrates five points from the Lizzie Hill site (41CP494) in Camp County. He described them as narrow-stemmed dart points or extensively reworked Wells points. Points C, D, H, and K on Figure 14 are points with ground stems; 20 percent of the Hill points have ground stems and are of local quartzite. Sixty-five percent of the Wells points of the Bolton collection have ground stems. Thus, some Wells points may have been reworked enough to be placed in this new type, and the Wells and Hill points are likely contemporaneous.

The Hill points are grouped into three classes according to shape and size. Points A-E on Figure 14 are among nine similar points of this shape, with rounded base, and are the largest size with lengths of 51-69 mm, widths of 19-22 mm, and thicknesses of 9-11 mm. The length-to-width ratio averages 2.93. They are long and slender. The length-to-width ratio of the five such points pictured by Perttula (2014) was 3.33. Points F-J on Figure 14 have generally flat bases with rounded corners. The length of these points is between $46-57 \mathrm{~mm}$, the width $16-25 \mathrm{~mm}$ and the thickness $7-12 \mathrm{~mm}$. Their length to width ratio is 2.71 . 

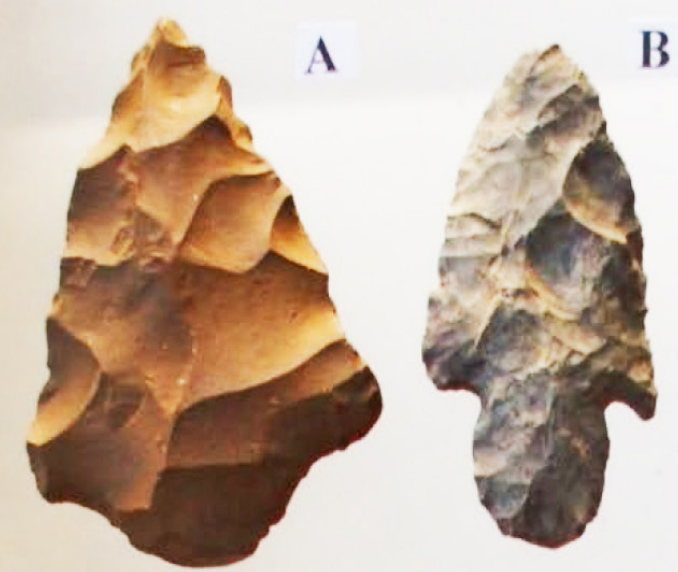

B

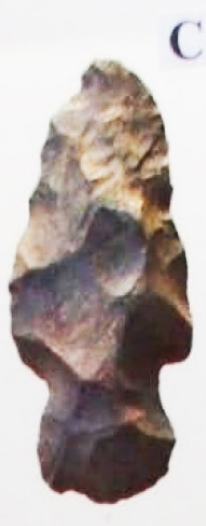

C
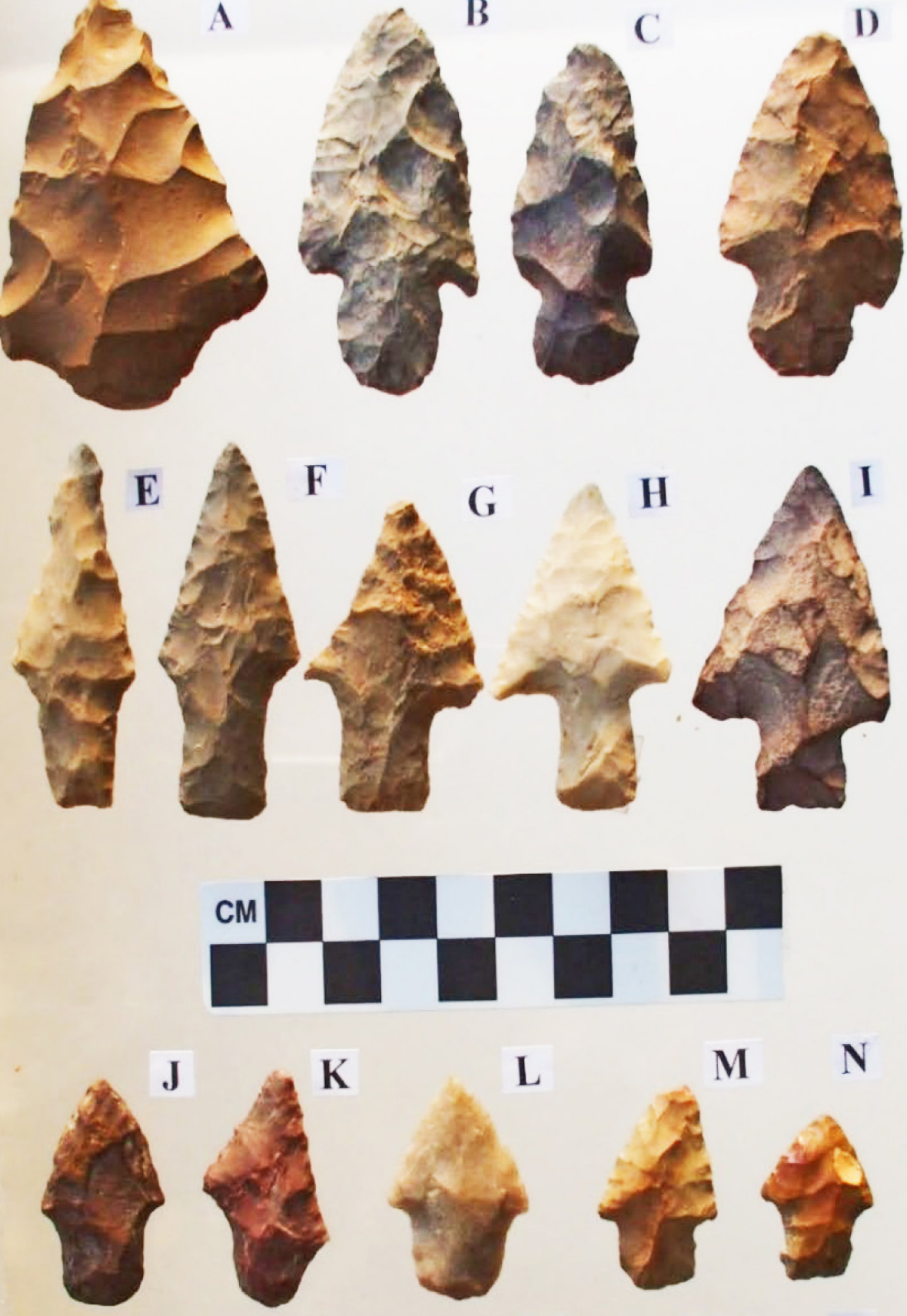

L
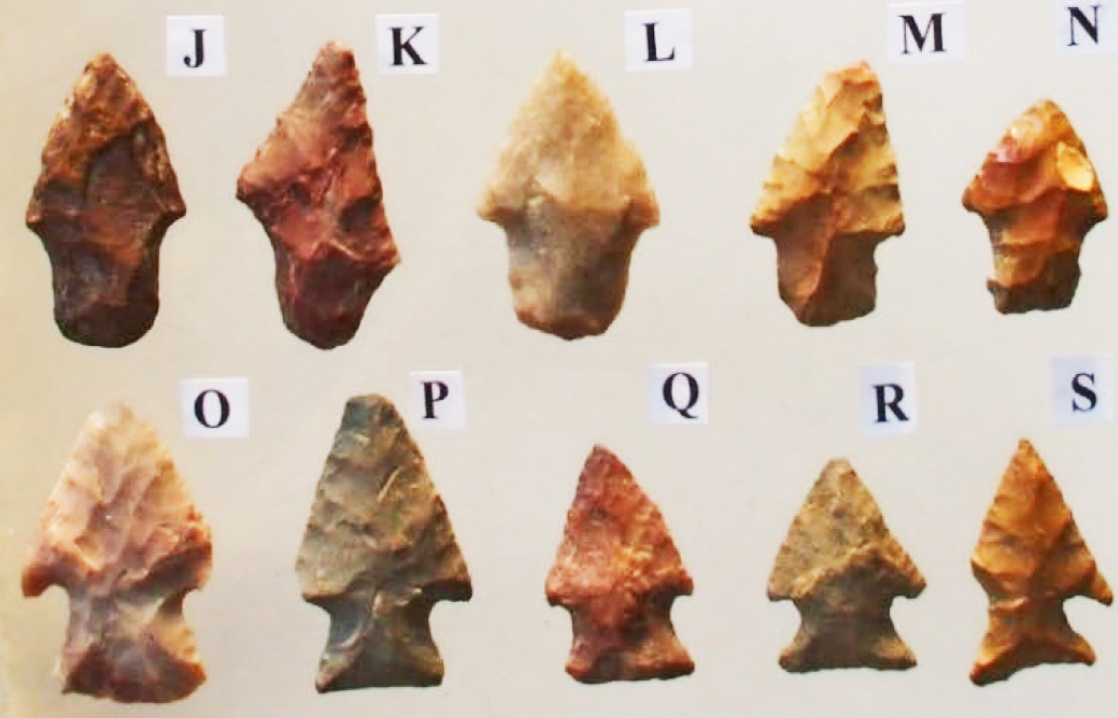

Figure 13. Late Archaic dart points in the Bolton Collection: A, Almagre; B-D, Axtell; E-I, Bulverde; J-N, Carralton; O-S, Ellis. 


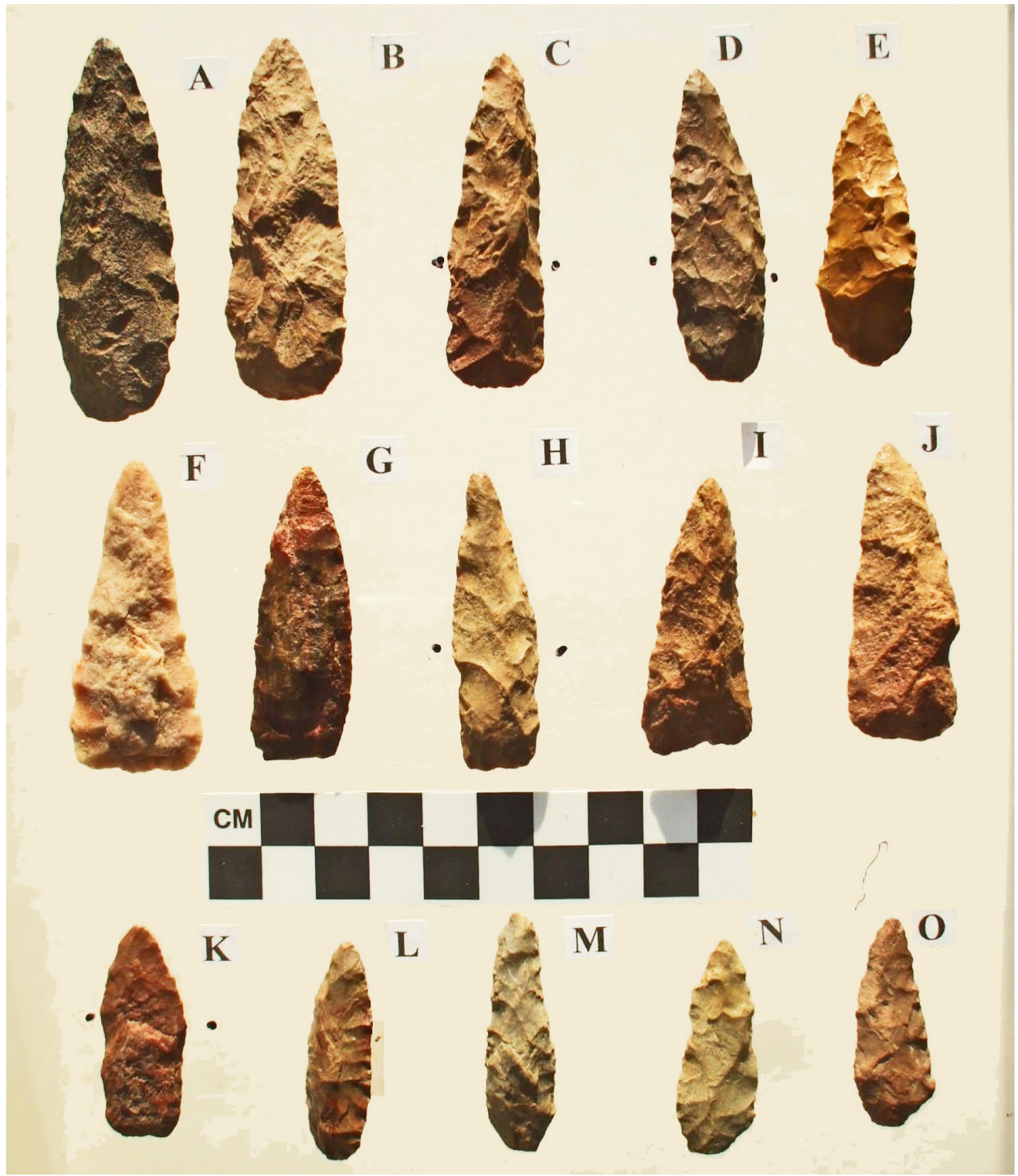

Figure 14. Hill points: A-E, largest points, rounded base; F-J, middle-length points, flat bases; K-O, smallest points.

Points K-O on Figure 14 are part of a group of 10 similar points that are smaller than those described above. Their lengths are from 32-45 mm, widths $13-17 \mathrm{~mm}$, and thicknesses 7-9 $\mathrm{mm}$. Their length-to-width ratio is 2.76. Thus, all of the stemless Hill points are characterized by their long narrow shape.

In Figure 15, points A-B are Epps, which are found at Poverty Point sites in far eastern Louisiana. Points C-E are Godley points. Five of the Godley points are of local quartzite, three are of novaculite, and two are of Central Texas chert. Points F-J are classed as Kent points, and they generally have a short straight stem. Johnson (1961) defined two varieties of Kent points, but I have not. A diversity of raw materials was used in the manufacture of this point type (see Table 1). 
Point K in Figure 15 is the single Motley point in the collection and it is made of petrified wood. These points, like the Epps type, are most prominent at Poverty Point in far eastern Louisiana. Points L-N on Figure 15 are Williams points. Six of the eight Williams points are of local quartzite and two are of non-local chert. Two Pontchartrain points are in the collection (see Turner et al. 2011). One is a maroon-colored quartzite of non-local origin that has careful edge chipping and an irregular meeting of the flaking at the blade medial ridge. The other point is a maroon chert with blade flakes, perhaps polished at their intersections from wear. These points are $65 \mathrm{~mm}$ and $60 \mathrm{~mm}$ long, respectively. These are primarily Louisiana point types that are also found in the Red River drainage.

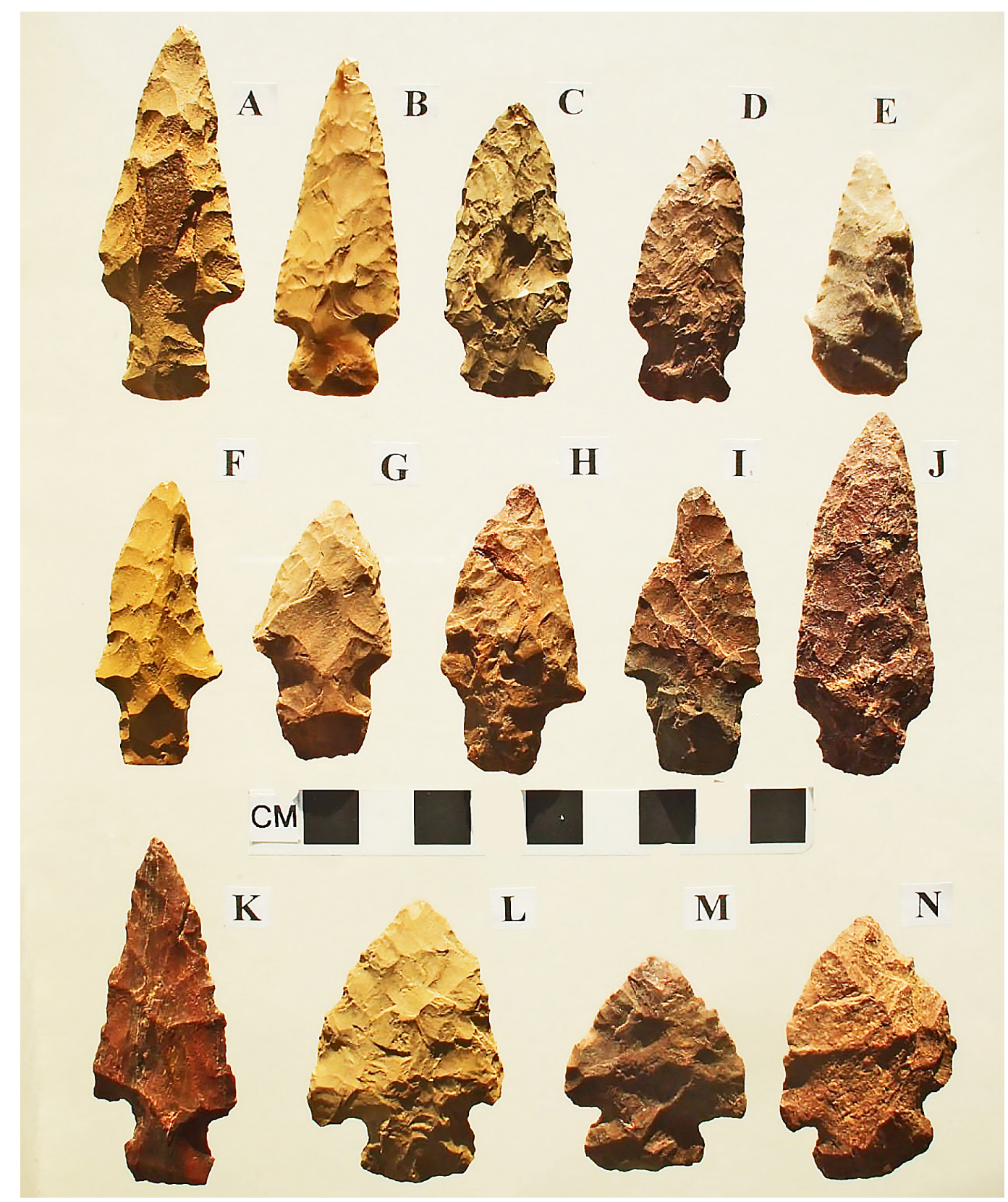

Figure 15. Other Late Archaic dart points in the Bolton Collection: A-B, Epps; C-E, Godley; F-J, Kent; K, Motley; L-N, Williams. 
In Figure 16A-J are Wells points $(n=54)$. These points vary from those with a barely perceptible meeting of the shoulder blade (Figure $16 \mathrm{~A}-\mathrm{F}, \mathrm{I})$ to the remainder that have well defined shoulders. More than 74 percent of the Wells points are of local quartzite, and 65 percent have ground stems and bases.

Points K-O on Figure 16 are Trinity points. Twenty-one of the 24 Trinity points are of local raw materials and thus were made by local peoples.

Johnson (1961) divided the Yarbrough points into three varieties: Dike, Maybank, and Lindale. These are all medium-sized points with the main differences being their stem shape and size. Johnson defined the Dike variety as points with lanceolate or almost triangular blades, stems with edges slightly convex,

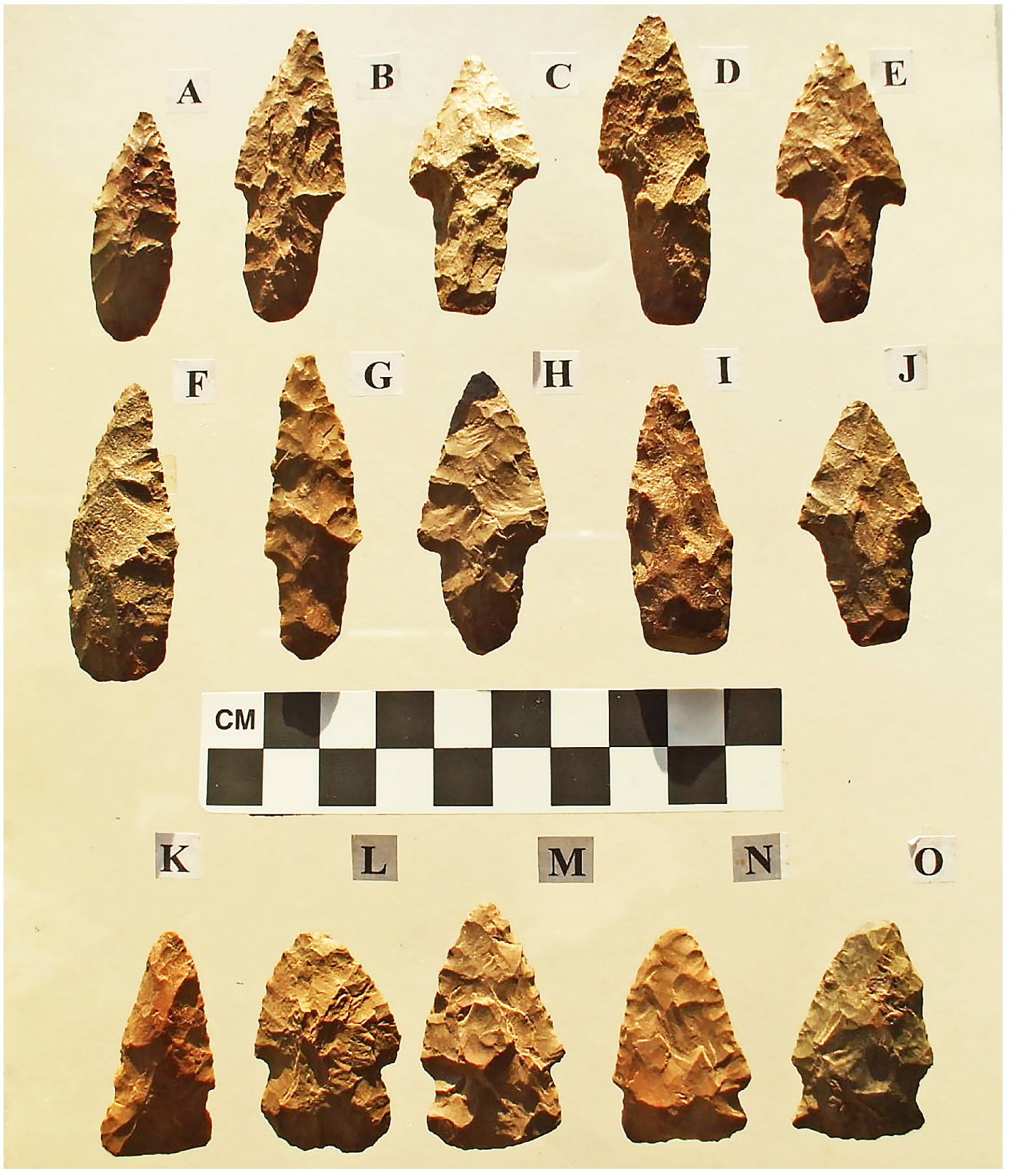

Figure 16. A-J, Wells points; K-O, Trinity points. 
and shoulders without barbs. The stem is about one-third of the point length, narrow near the shoulder, and expanding to the base, leaving a concavity on the edges, with a straight and flat base. An examination of all the Yarbrough points showed that 79 percent have very slight ground stems and bases, but not the obvious grinding of the Wells points. Yarbrough points are illustrated in Figure 17.

The upper row in Figure 17A-E, are variety Dike $(\mathrm{n}=33)$. The distinguishing feature of the variety Maybank ( $\mathrm{n}=36$ ), as seen in Figure 17F-J, is the stem. This stem has both a concave base and stem edges. The stem length varies from about a quarter to a third of the length.

The variety Lindale variety is by far the most numerous of the Yarbrough points (see Figure 17K-O). The blade is triangular to subtriangular, with edges convex to almost straight, and with stems that are a

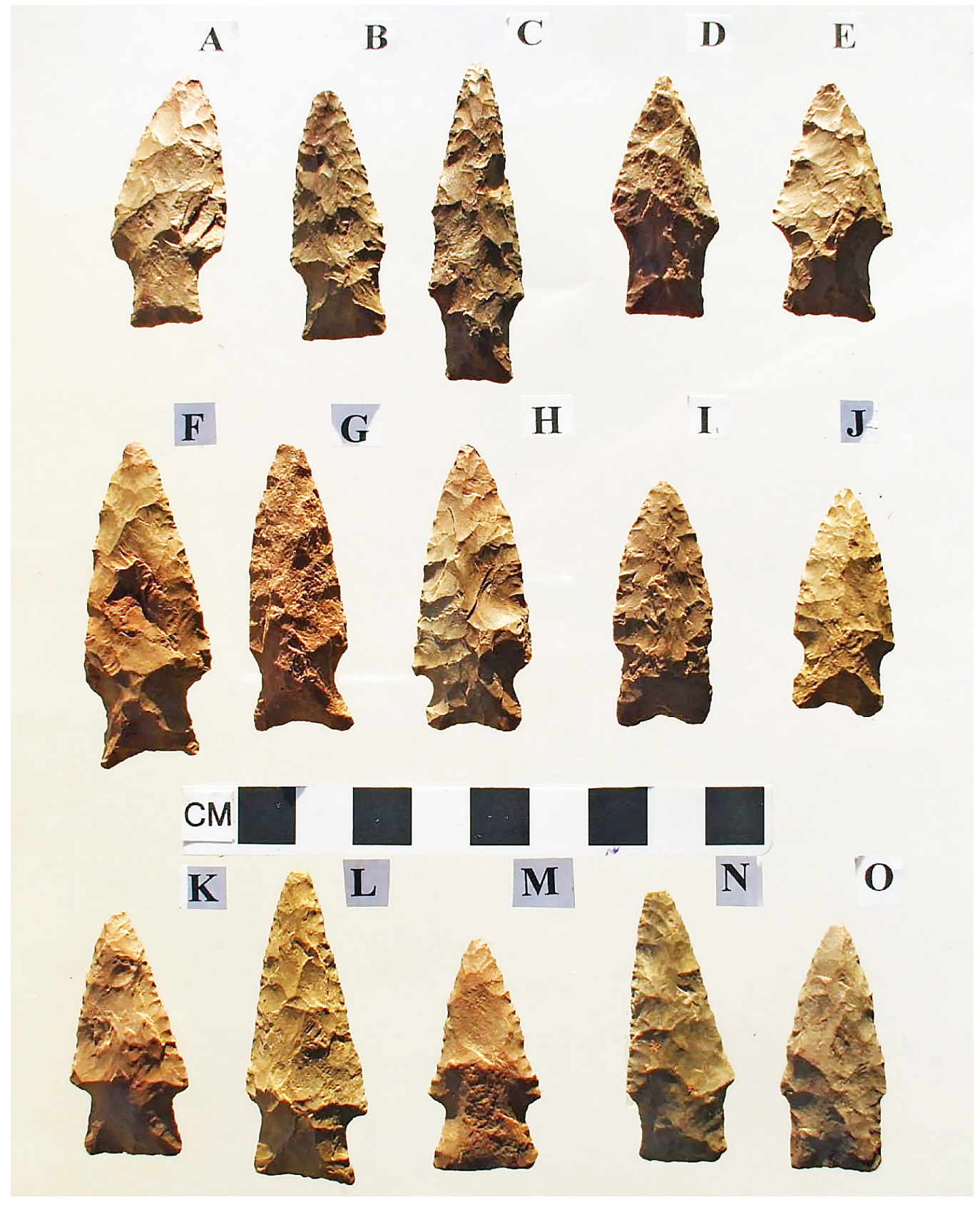

Figure 17. Yarbrough points: A-E, variety Dyke; F-J, variety Maybank; K-O, variety Lindale. 
third to a quarter of their length. The stem expands from the shoulder to the base with near straight edges. The base is straight or nearly so.

The Yarbrough points are the most prevalent point during the Late Archaic in Camp County. These points comprise 55 percent of the Late Archaic point assemblage.

\section{The Middle Archaic Period (ca. 8000-5000 B.P.) Dart Points}

Figure 18A is the lone Evans point in the Bolton collection. Evans points are primarily of Louisiana origin. The point is made of jasper but the raw material does not look like the local variety, but may be from a Red River jasper source.

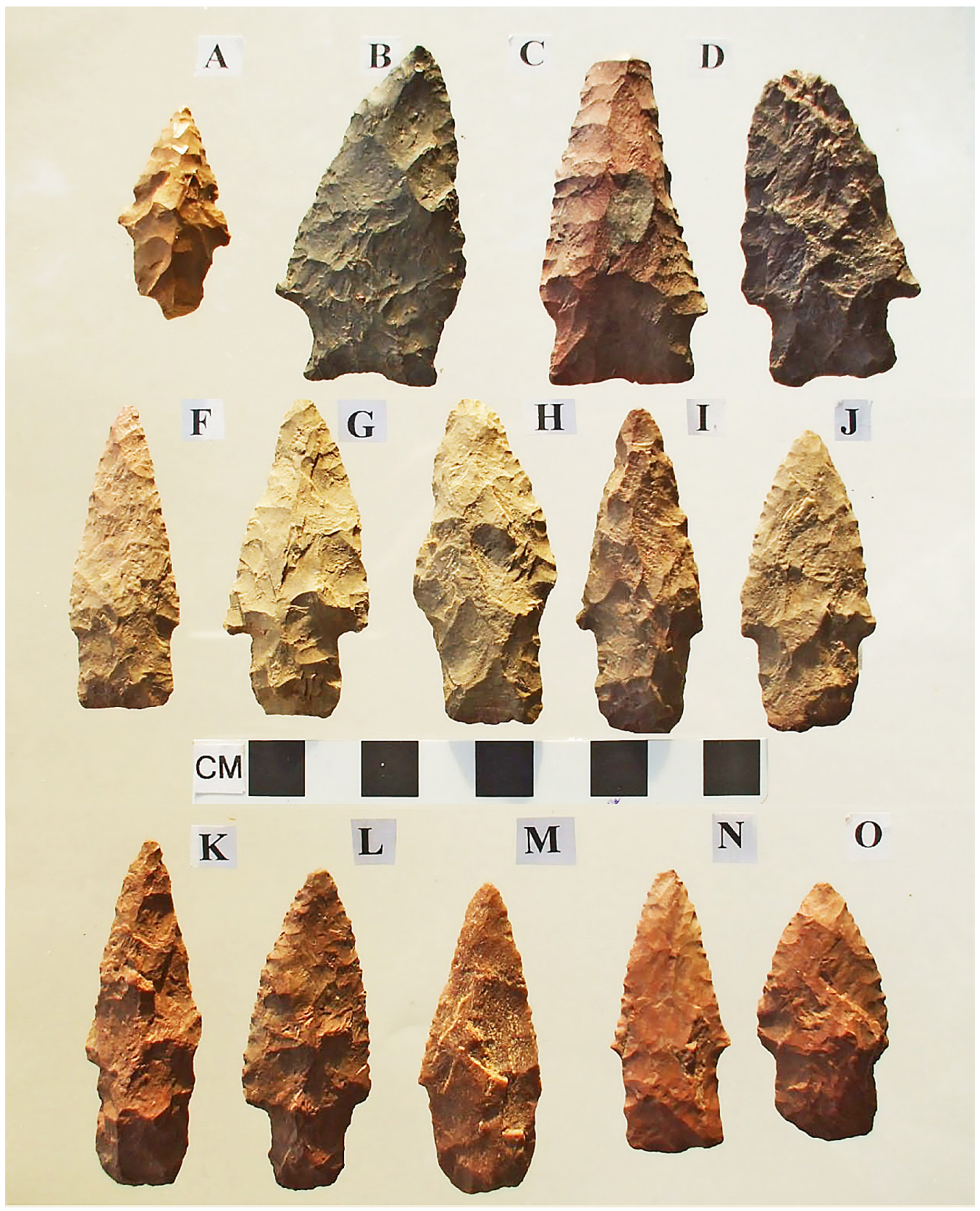

Figure 18. Middle Archaic points in the Bolton Collection: A, Evans; B-D, Johnson; F-O, Morrill. 
Points B-D on Figure 18 are classified as Johnson points. Four of the seven points of this type have been smoothed on the stem edges. Johnson points are found in the adjoining corners of Texas, Oklahoma, Arkansas and Louisiana.

Points F-O on Figure 18 are Morrill points ( $\mathrm{n}=37$ ). These are the most numerous of the Middle Archaic points in this collection. As 76 percent of these points are of local quartzite and jasper, their makers were certainly local inhabitants. Eight of the 26 quartzite Morrill points fluoresced under the ultraviolet "black light," indicating they were heat treated (see Table 2).

Johnson divided the Morrill points into varieties Slocum and San Pedro. Of the 10 points pictured, Points F, H, L-M, and O on Figure 18 meet his definition of variety San Pedro. The remaining points are variety Slocum. Of the 37 Morrill points, all but five variety Slocum points have edge grinding that is more distinct than Yarbrough, but not as pronounced as on Wells points.

Perttula (n.d.) prepared a paper for publication, in a book on the Calf Creek culture, entitled "The Distribution of Calf Creek Series Sites and Points in East Texas." In this paper, he referred to points identified as Andice, Bell, or Calf Creek as the Calf Creek series points without breaking them down further, primarily because he did not believe they were separate types.

In his study, Perttula listed 149+ points and 74 sites and localities where the points were located in East Texas. In the Big Cypress Creek basin, where the Bolton collection was accumulated, Perttula listed 41 known sites and 100 points. The Sulphur River basin had nine sites and 16 points. Both the Sabine and Neches River basins contained eight sites, with 10+ points in the Sabine and 13+ points in the Neches basins. The Red and Angelina River basins each had five Calf Creek series points with three sites on the Red River and five on the Angelina River. The major clusters of these points are in the Blackland prairie in the Sulphur River basin, the Post Oak savanna in the Big Cypress, Sabine, and Neches river basins, and the western edges of the Pineywoods in the Big Cypress and Sabine River basins.

Perttula dated the time period of these Calf Creek people from 6000 to 5800 B.P., in the latter part of the Middle Archaic period. He also noted that the environmental conditions at 6000 B.P. were drier than today. These conditions led to an eastward expansion of grassland and perhaps an eastward expansion of bison as well. He further noted the high quality of the chert used by Calf Creek people to make projectile points found in East Texas and postulated that the people who left them came from both the west and north. Those from the west would have brought points and raw material of Central Texas chert, and those from the north would have brought Frisco Chert and the Ouachita Mountains novaculite from the central and southeast Oklahoma region.

There are 16 Calf Creek points in the Bolton collection (Figure 19). Seven of these, including Figure 19B-E and Figure 19G, are novaculite. I classify these seven points as Calf Creek based on the origin of the raw materials used in point manufacture. Point $\mathrm{A}$ is a medium tan jasper with a red cast at the stem base. This point is the same size, shape, and craftsmanship as points B and C, and is probably Red River jasper that originated in the Ouachita Mountains, as did the novaculite. One of the novaculite points is reworked. The stem is intact, but the long barbs are missing. The reworked blade is a few $\mathrm{mm}$ shorter than the smoothed stem. The remaining novaculite point is of two shades of gray chert with a distinct line of demarcation between the two; the darker chert is the most translucent.

The remaining eight Calf Creek series points are of Central Texas chert. Five of these are classified as the Bell type because of their size, shape, and raw material (see Figure 19I-L). Point J is a light "khaki"-colored chert with a dark brown tip. The remaining Bell points are shades of dark brown-gray chert with clouds of lighter brown. The remaining Central Texas Bell point consists of an intact stem and a reworked blade about half the stem length. 


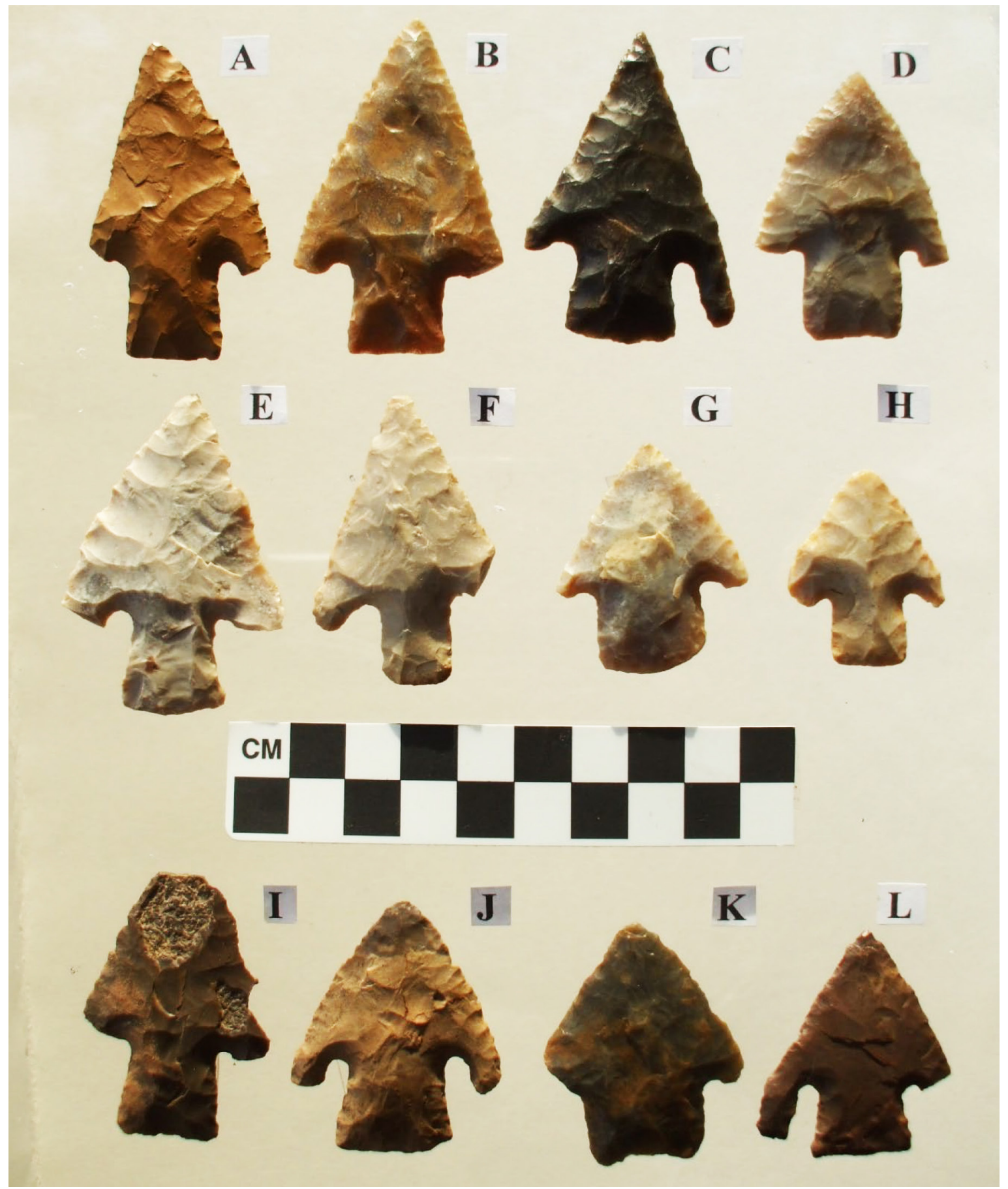

Figure 19. Calf Creek series points.

The remaining two points (see Figure 19F, H) are a very light gray-khaki-colored chert. One is the size of the Bell points and the other is about 67 percent as large. The edges of both are translucent, and each has a rectangular stem. Both points differ slightly from the Calf Creek point type, as the barb notch is not parallel to the stem, but diverges at a nearly 45-degree angle. The one remaining barb extends to about 40 percent of the stem length and is rounded on the end. These points are related to, but do not conform exactly, to the Calf Creek shape. They are of Central Texas chert. 
An examination of these 16 points with ultraviolet light showed that Point A in Figure 19, the jasper point, fluoresced red under the broad band excitation as did the jasper points of the Woodland period dart points. There was no response to $365 \mathrm{~nm}$ ultraviolet light. Six of the seven novaculite points responded to the $365 \mathrm{~nm}$ excitation. Colors were a pale "dirty" yellow, bright white, white, white with a yellow cast, or a "dirty" white.

Novaculite point B in Figure 19 did not fluoresce. Of the eight Calf Creek series points of Central Texas chert, two did not fluoresce, but six did with a yellow cast, white, orange cast, yellow, or orange tint.

\section{Early Archaic Period (ca. 8000-10,000 B.P.) Dart Points}

Breckenridge points appear early in the Early Archaic period. They are characterized by Johnson (1989) as a possible "grandchild" of the classic Dalton point. Ray (2016:48-50) and other researchers describe it as a variant, and presumably, descendant, of Dalton points. An approximate age range of 9500-9800 years B.P. has been suggested by Ray (2016).

Seven points have been classified as Breckenridge in the Bolton collection (Figure 20). Each of the points is ground on the stem edges and the base. The blades of all points, except Figure 20F, have a counter-clockwise twist when viewed from the tip. This twist results from right hand edge beveling. Point G on Figure 20, which has been re-sharpened, has the same twist, with a resulting prominent median ridge. This appears to be a perforator.

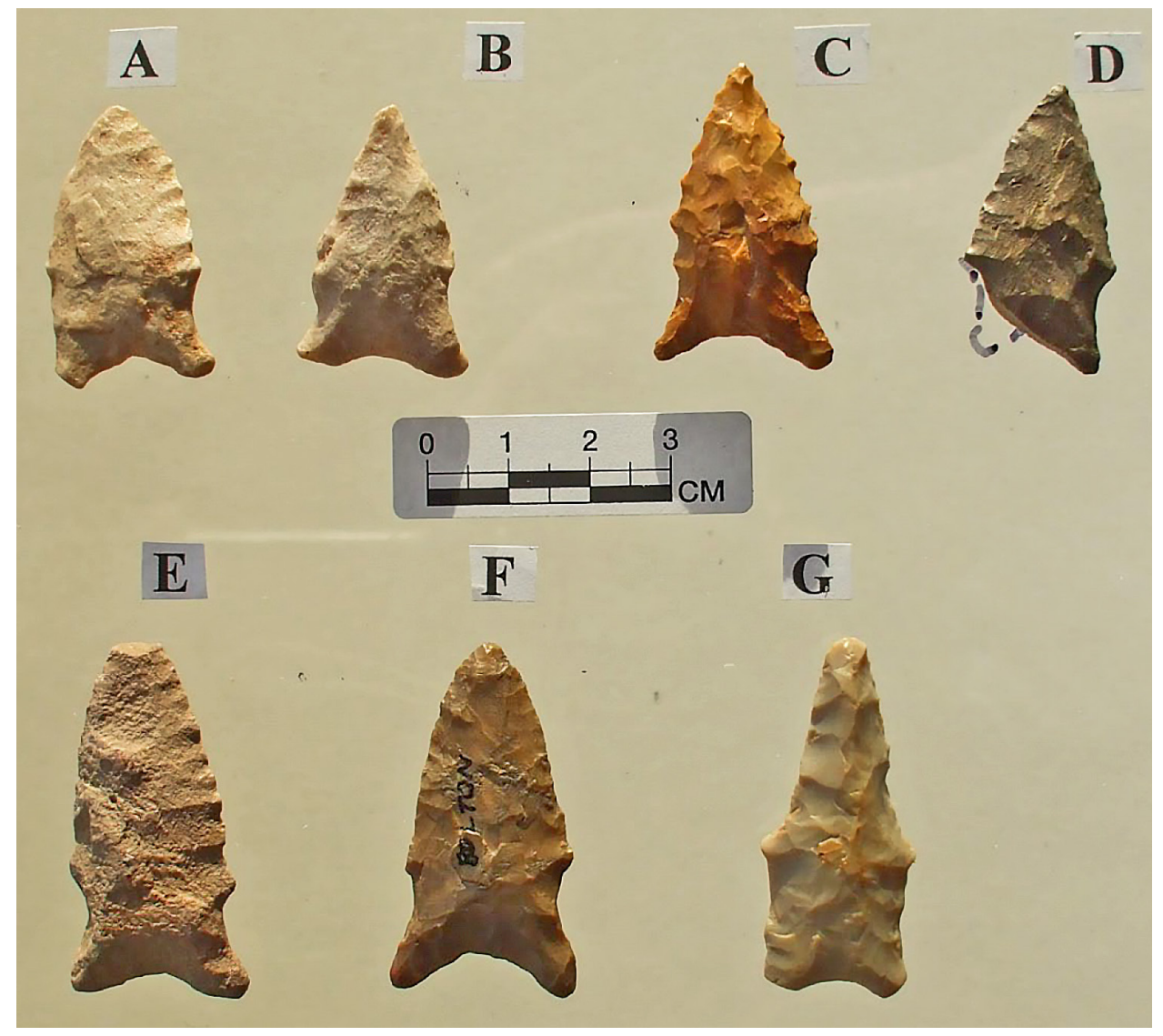

Figure 20. Breckenridge points. 
All of the Breckinridge points are made from non-local cherts. Points A and B in Figure 20 are fine grained "dirty" white quartzite with small mica inclusions; point $\mathrm{E}$ has the same texture but a slightly pinkish-maroon cast. Point $\mathrm{C}$ is a mottled light tan to maroon mix, with a glossy surface, and serrated edges. Points $\mathrm{D}$ and $\mathrm{F}$ are dark brown-gray chert with a semi-glossy surface. Point $\mathrm{G}$ is a light gray, glossy, and lustrous chert.

An inspection of these points with ultraviolet light showed that points A, B, and G on Figure 20 fluoresce under $365 \mathrm{~nm}$ excitation. Point $\mathrm{G}$ has a pure yellow glow, whereas points A and B are a splotchy yellow-white with a non-fluorescent mottling. Point $\mathrm{C}$, which is jasper, does not respond to the $365 \mathrm{~nm}$ excitation but has a red fluorescence under the broad spectrum ultraviolet "black light." Points $\mathrm{D}$ and $\mathrm{F}$ do not fluoresce under either excitation. As stated previously, none of these points are of local chert. Point $\mathrm{G}$ is problematical as to its identity. Point $\mathrm{C}$, a jasper point, is not the same raw material as the local jasper. The origin of the cherts of the remaining points is unknown.

There is one Hoxie point (Figure 21G), of Early Archaic period age, in the collection. It is a maroon chert with a few irregular khaki-colored splotches. The dimensions are: length $65 \mathrm{~mm}$, maximum width $23 \mathrm{~mm}$, shoulder width $21 \mathrm{~mm}$, neck width $12.5 \mathrm{~mm}$, and width at the ears of $13.5 \mathrm{~mm}$. The stem length is $11 \mathrm{~mm}$. The maximum thickness is $9.5 \mathrm{~mm}$. The indentation at the base is $1 \mathrm{~mm}$. The point is generally irregularly flaked with shallow flake scar intersections. The cross section is biconvex but approaches a median ridge on one side. The chert is probably a very fine-grained quartzite. It has the same appearance as several Morrill points that have been heat treated. The point fluoresces red under broad-band "black light," indicating it also has been heat treated.

\section{Paleoindian Period 10,000 B. P. and Before}

There are two Scottsbluff points in the Bolton collection (Figure 21A, D). Point A has the thickened biconvex cross section typical of Scottsbluff. Recent flakes from one edge show a medium brown chert. Ultraviolet inspection with $365 \mathrm{~nm}$ light produced a yellow-orange fluorescence; the point is probably from a Central Texas raw material source. The blade edges are translucent. This point was re-worked into an end scraper after the stem was broken away. In its present form, the point is $81 \mathrm{~mm}$ in length, with a maximum blade width of $26 \mathrm{~mm}$ and is $9 \mathrm{~mm}$ in maximum thickness.

Point D in Figure 21 is a lustrous light-gray chert with a slight tan appearance. The stem is intact and has grinding on both the base and edges. The blade has been reworked, resulting in a very thick medial ridge unlike the biconvex cross section of point A. The point fluoresces a yellow-white under $365 \mathrm{~nm}$ ultraviolet excitation and is probably from a Central Texas source. The base has been thinned with basal thinning flakes. The point tip is missing. It is possible that this point was being modified into a Red River knife or a shorter dart point before it was abandoned.

A third Scottsbluff point (see Figure 21B) was not in the Bolton collection but I found it approximately 50 m south of the Sam Carpenter Garden Plot Site (41CP496, see Perttula 2013a:40). The location was an old abandoned cow shed lot. The point was found on the deflated surface of the underlying red clay. No other artifacts were present there. The point is an Eared Scottsbluff. Ritzenthaler (1967) first recognized this point type and included it in "A Guide to Wisconsin Indian Projectile Point Types." Other publications that picture Eared Scottsbluff points are Hill (1994) and Kuehn and Clark (2012). These points were found in east and west central Wisconsin. The Wisconsin raw material used for the point manufacture was Hixton silicified sandstone in the west and Marquette rhyolite and siltstone in the eastern part of the state. The Camp Co. Eared Scottsbluff is probably rhyolite, based on Internet pictures of this raw material. Rhyolite is widespread and is present in several states including Missouri and Arizona. I believe this eared Scottsbluff point probably originated in Wisconsin and found its way to Camp County some 9000-10,000 years ago. 


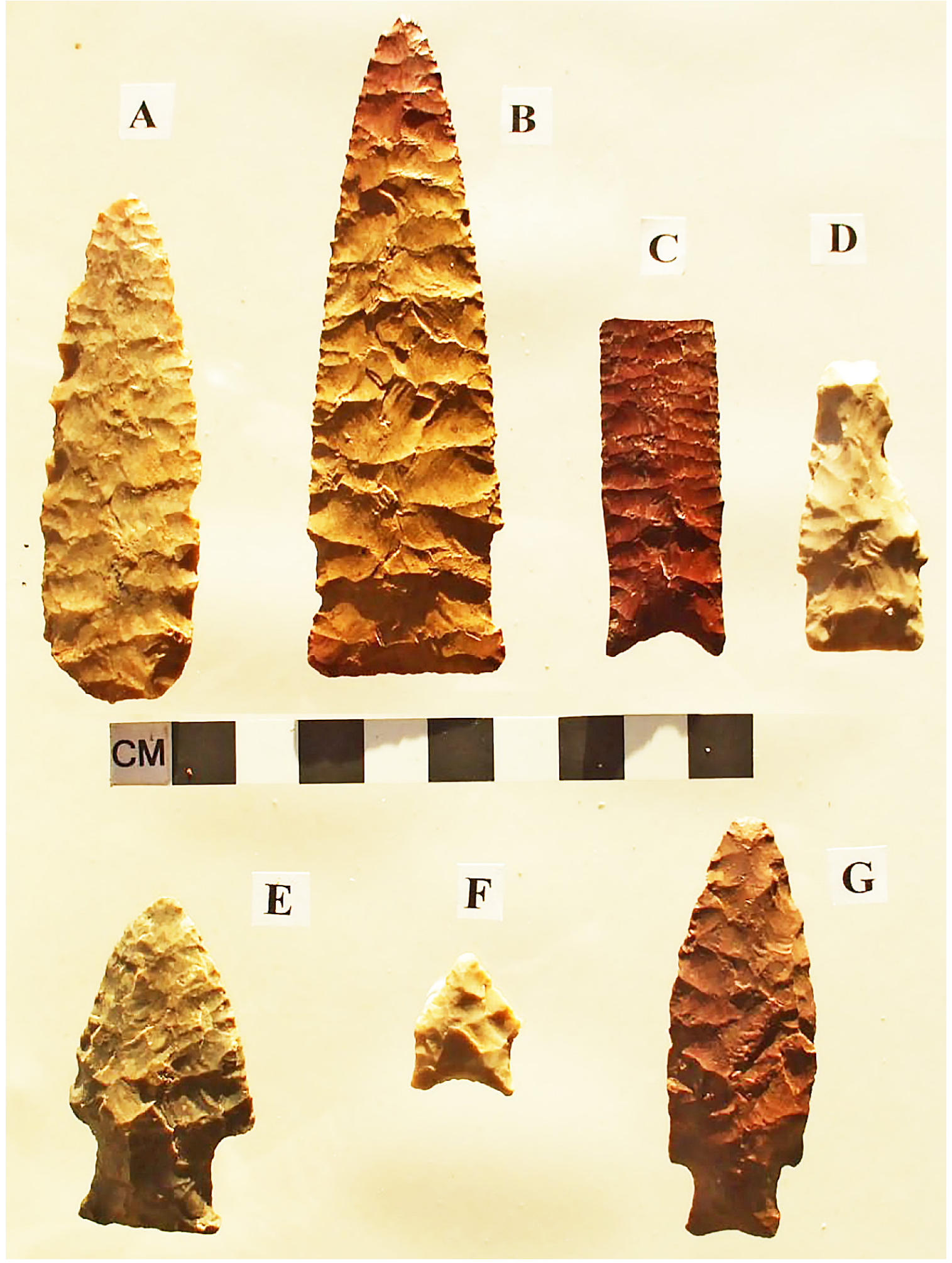

Figure 21. Late Paleoindian points and an Early Archaic Hoxie point. 
There is one large part of an Eden point in the Bolton collection (see Figure 21C). The basal section, or stem, is ground for $24 \mathrm{~mm}$ on one side and $25 \mathrm{~mm}$ on the other. The basal concavity is also smoothed. One basal side is thinned with two large flakes and the other with several smaller flakes. The pressure flaking on the blade edges is symmetrical, very shallow, and delicately done, and converges with the opposite flakes in a medial ridge that resulted in a diamond-shaped blade cross section. The diamond-shaped blade cross section is the determining factor in separating the Eden from the Scottsbluff type, as the latter have a bi-convex blade cross section. Measured from the snapped end of the point there are nine, 10, eight, and nine flakes per $25 \mathrm{~mm}$ along the four blade edges. The length of the broken point is $53 \mathrm{~mm}$, and the maximum width is $19 \mathrm{~mm}$ at the end of the lateral grinding and $18 \mathrm{~mm}$ at the basal ears. The thickness is $7 \mathrm{~mm}$. The point material is a maroon chert with a near vitreous luster, opaque, and homogeneous, with no visible inclusions. It is a chert foreign to East Texas. It does not fluoresce when exposed to the broad band "black light" or the $365 \mathrm{~nm}$ ultraviolet light.

A comparison of the dimensions of the Bolton collection point and the mean dimensions of the 41 Eden points from the Horner 1 site in Wyoming, the type site for these points, is:

$\begin{array}{lll} & \text { Horner 1 } & \text { Bolton } \\ \text { Blade Width } & 19.31 \mathrm{~mm} & 19.0 \mathrm{~mm} \\ \text { Blade Thickness } & 6.66 \mathrm{~mm} & 7.0 \mathrm{~mm} \\ \text { Stem Width } & 17.44 \mathrm{~mm} & 17.5 \mathrm{~mm} \\ \text { Stem Thickness } & 5.88 \mathrm{~mm} & 5.1 \mathrm{~mm}\end{array}$

The only difference between the Horner 1 points and the Bolton point is the basal shape of the Bolton specimen that is similar to lanceolate points of the period.

Figure 21F pictures one San Patrice point, variety Hope. Webb et al. (1971) and Duffield (1963) illustrate and describe these points. The dimensions of this point are: length $22 \mathrm{~mm}$, width at the shoulder $17 \mathrm{~mm}$, and width at the base of $16 \mathrm{~mm}$, width at the lateral notch is $14.5 \mathrm{~mm}$, and its maximum thickness is $5 \mathrm{~mm}$. The material is a homogenous light, near lustrous, gray-tan in color and translucent on the edges, and a material foreign to this locality. These parameters match well with Webb's dimensional ranges, but several of the measurements are smaller. The length-to-width ratio is 1.29 as compared to Webb's ratio of 1.28. This is a small point. When examined under $365 \mathrm{~nm}$ ultraviolet light, the point fluoresces a white-yellow. The raw material is probably novaculite.

One additional Late Paleoindian point is in the Bolton collection. This is a Wilson point (Figure 21E). The Wilson point has a broad, thick, expanding stem with a straight base. The blade is biconvex in cross section and the planform mirrors that pictured by Turner et al. (2011) and Bousman et al. (2004), particularly the Wilson points from the Wilson- Leonard site (41WM235). The material is a dark gray Central Texas chert with a minor light brown mottling. The dimensions of the point are: length $53 \mathrm{~mm}$, width at the shoulder 30 $\mathrm{mm}$, width at the neck $18 \mathrm{~mm}$, and width at the basal ears $25 \mathrm{~mm}$. The maximum thickness is $10 \mathrm{~mm}$ at the shoulder. The only difference from the Turner et al. (2011) and Bousman et al. (2004) descriptions with this Wilson point is that it has no perceptible stem or basal grinding. The point has a bright yellow glow when exposed to $365 \mathrm{~nm}$ ultraviolet light.

Plainview points are another Late Paleoindian type as described by Suhm and Krieger (1954) and more recently by Bousman et al. (2004). Suhm and Krieger (1954) illustrate 28 examples of these lanceolate points that have lengths of $4.5-8 \mathrm{~cm}$, widths of $1.8-2.8 \mathrm{~cm}$, basal widths of $2.0-2.6 \mathrm{~cm}$, and a basal concavity of 1-8 $\mathrm{mm}$.

The Bolton collection of Plainview points are pictured in Figure 22A-F, H-J. Point A is a light gray homogeneous chert with a vitreous luster and translucent edges. Basal and stem grinding is present, with the stem grinding extending 38 percent of its total length. Parallel flaking is present roughly perpendicular to the blade edge. The blade cross section is convex. Both blade edges are finely serrated. Johnson (1989) believed Plainview knappers may have borrowed this trait from the Dalton peoples already living in Northeast Texas. 


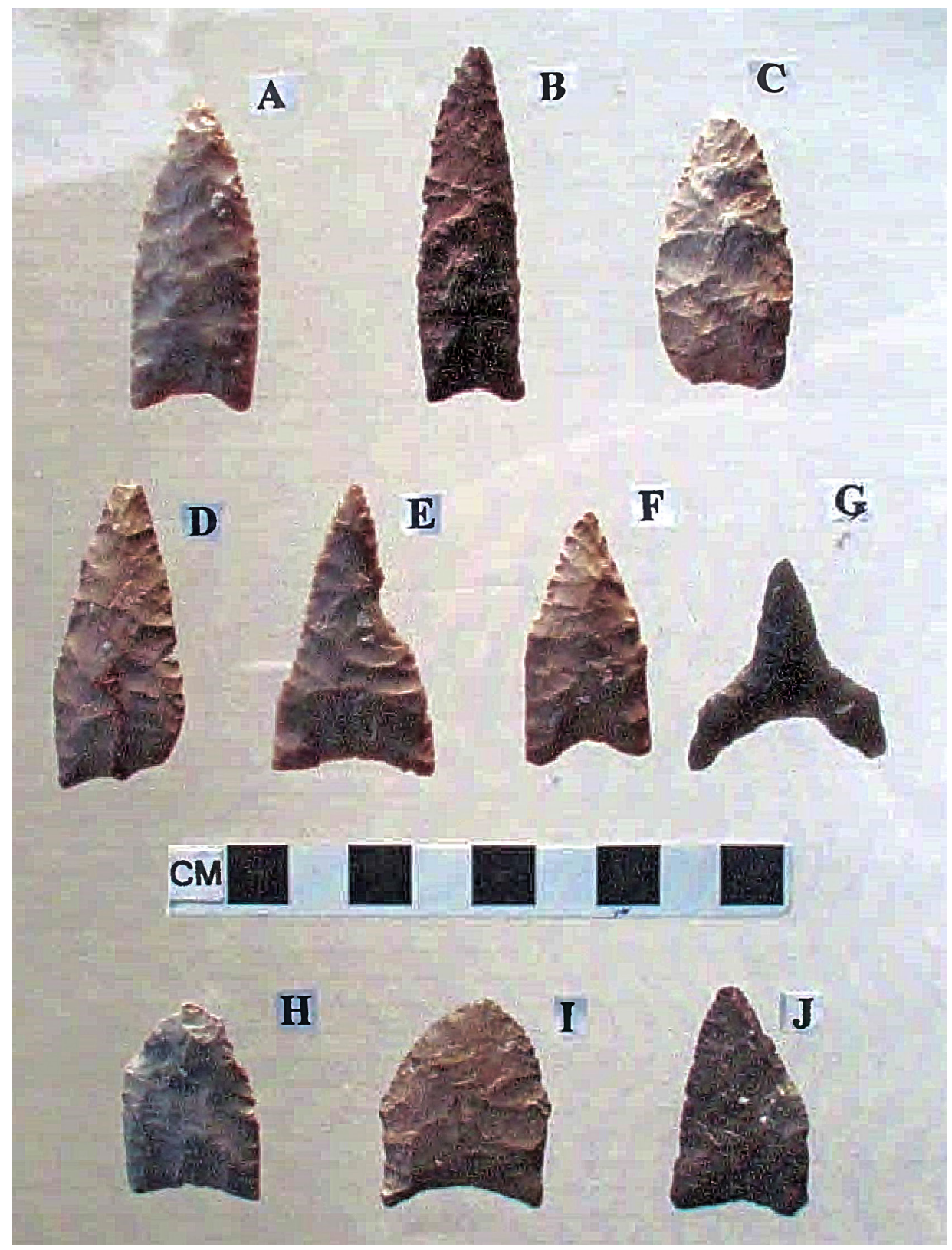

Figure 22. Plainview points: A-F, H-J; G, unidentified Late Paleoindian or Early Archaic lanceolate point made into a perforator.

Point B is a dark chocolate brown chert on the proximal end with an abrupt change to a medium brown color on the distal end; it is translucent on the edges. The stem is lightly ground for approximately $1 \mathrm{~cm}$ on each edge and also lightly ground on the base. Flaking is parallel and perpendicular to each edge, resulting in a very distinctive medial ridge on each face. The chipping left a roughly serrated edge. This may be a reworked point. Although it is more-slender than most Plainview points, it falls within the parameters noted by Suhm and Krieger (1954).

Point $\mathrm{C}$ is a white-tan chert. Stem and basal grinding are present. Its blade cross-section has a medial ridge. The blade also has two vugs less than $5 \mathrm{~mm}$ in length with crystalline interiors. Frisco flint originating from southeast of Norman, Oklahoma, in the Arbuckle Mountains sometimes contains vugs (see Evans 1958). The range of colors reported for Frisco chert could include that of Point C. The point is opaque. 
Points D-F are all re-sharpened but are long enough to retain a lanceolate form. Each has a pronounced medial ridge. Point $\mathrm{D}$ has a counter-clockwise body twist of about 15 degrees (when viewed from the tip) as a result of right edge beveling. Points H-I are also reworked. They have basal grinding and edge grinding up to the beginning of the reworked edges.

Point $\mathbf{J}$ is a dark gray chert with occasional red to white small inclusions. The surface is near lustrous. It has basal and edge smoothing. The right edge has a 22- $\mathrm{mm}$ long burin flake removed that may have been the result of impact from use. This break left the point usable but not as symmetrical as before.

The perforator $\mathrm{G}$ is a black and very translucent novaculite. It has been ground on the outer edges, and in the basal cavity. Basal thinning flakes are prominent on both faces of the artifact. This was probably made from some unknown variety of Late Paleoindian or Early Archaic lanceolate point, but it is not a Plainview.

Points A, C, E-F, and H-I in Figure 22, when examined under $365 \mathrm{~nm}$ ultraviolet light, respond with yellow-white to yellow shades of fluorescence. The chert of all but point $\mathrm{C}$ is a light shade of gray and nearly fully lustrous in appearance. These are probably raw materials of Central Texas origin. Point $\mathrm{C}$ is opaque, has a dull surface, but does show a yellow glow, but it is not as pronounced as the others.

Points B and $\mathrm{J}$ in Figure 22 have similar dark colors. They are also near-lustrous but do not respond to the ultraviolet light. Point $\mathrm{D}$ is similar to $\mathrm{E}$ and $\mathrm{F}$ in its color but has a dull surface finish, is opaque, and does not fluoresce.

Clovis points are Late Pleistocene and Early Paleoindian era points that date from about 13,500 to 12,700 B.P. One Clovis point is in this collection (Figure 23). Two Clovis points from Camp County are pictured in Nelson and Perttula (2003). Four additional Clovis points from Camp County are known but are not yet published in the archaeological literature. Thus, a total of seven Clovis points have been identified from this small county.

The Bolton Clovis point has a present length of $83 \mathrm{~mm}$ (approximately $4-5 \mathrm{~mm}$ is missing from the tip). The blade width at the juncture of the stem and reworked blade is 28 $\mathrm{mm}$ and the width at the base ear tips is 26 $\mathrm{mm}$. The maximum basal concavity is $4.5 \mathrm{~mm}$, and the maximum blade thickness is $9 \mathrm{~mm}$ at the end of the flutes.

The point was re-sharpened, resulting in near straight edges and a triangular blade shape instead of the usual straight to convex form. There is a medial ridge beyond the flutes. I believe the "U" notch in the base occurred after the original knapping of the point, as the flaking pattern is different, and there is no basal grinding of the notch.

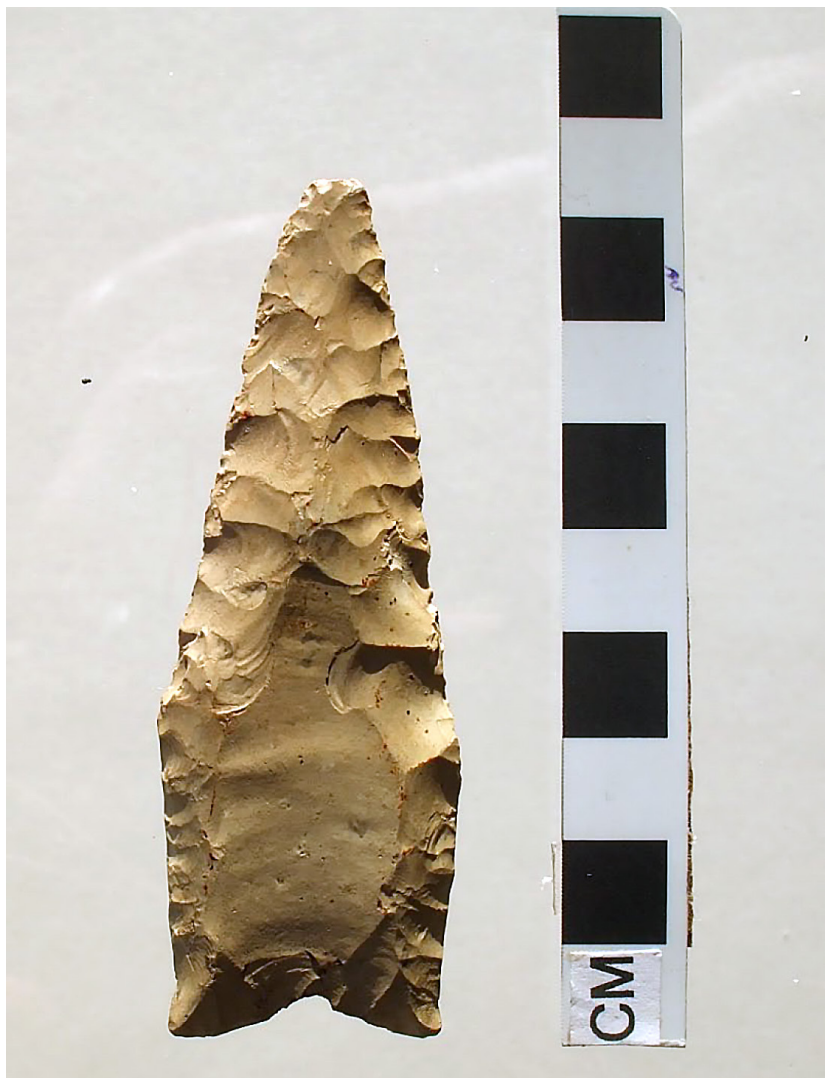

Figure 23. Clovis point. 
The chert color is a light tan, and the surface is near lustrous in appearance. The point fluoresces only to the $385 \mathrm{~nm}$ ultraviolet light source, and thus the raw material probably originated in Central Texas.

Flute scars are $41 \mathrm{~mm}$ by $17 \mathrm{~mm}$ on one side and $41 \mathrm{~mm}$ by $18 \mathrm{~mm}$ on the other, as measured from the bottom of the "U"-shaped depression in the base. The stem is ground to the intersection with the re-sharpened blade, a distance of $25 \mathrm{~mm}$ on one side and $30 \mathrm{~mm}$ on the other. The un-notched part of the base is also smoothed.

The Dalton points $(n=5)$ of this collection are pictured in Figure 24. All of the points are of foreign chert.

Original first stage Dalton points are long lanceolate forms. The second chipping stage or reworking of a damaged point results in a shorter point or tool resharpened by beveling the right edge, sometime left, when viewed with the point up. The original lanceolate form can be confused with Plainview points (see Johnson (1989; Turner et al. 2011). The third stage of reworking results in rounded end scrapers or perforators. No third stage points are in this collection. Turner et al. (2011) provide excellent drawings of the stages of life of a Dalton point.

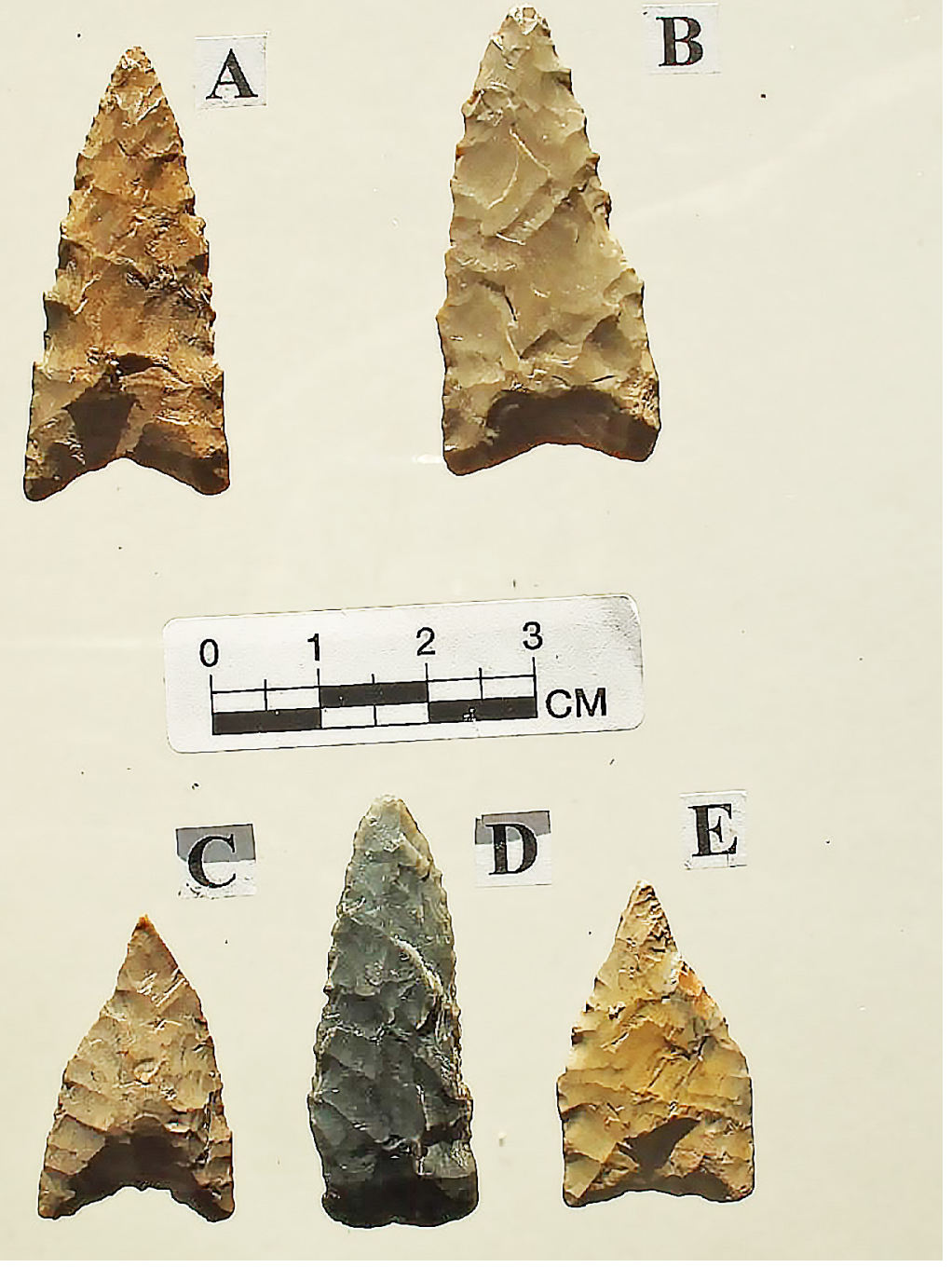

Figure 24. Dalton points. 
The five Dalton points of this collection have all been reworked and are second stage points. Point B in Figure 24 is a light, lustrous, gray chert and fluoresces under $385 \mathrm{~nm}$ ultraviolet light. The other four points do not. All points have pronounced stem and basal grinding and a medial ridge that resulted from the re-sharpening. Point $\mathrm{A}$ is a mottled light brown and medium gray chert. Point $\mathrm{C}$ is a medium lustrous gray chert, and point $\mathrm{E}$ is a light gray-tan chert. Point $\mathrm{D}$ is a dull black chert.

\section{Remarks about the Paleoindian and Early Archaic Periods}

Johnson (1989) published an essay on the incursion of Great Plains people into the Eastern Woodlands. He called these people "interlopers." The Eastern Woodlands edge at this time included what is now Bastrop County and extended north-northeast to the Oklahoma-Kansas border. This woodland intersects that border approximately $25 \mathrm{~km}$ west of the northeast corner of Oklahoma. It includes the Ozark and Ouachita Mountains of eastern Oklahoma and southern Missouri, westward fingers of woodland along the Red River and in other river systems draining toward the southeast. To the southwest, a finger of woodland continues from what is now Bastrop County. Within this area, the woodlands stop at the coastal savannas along the Gulf Coast.

Johnson concluded that this eastern margin and the interior were already occupied by Dalton and San Patrice peoples, whom he identified as the "homefolks" who who were already there after the Clovis time period. In his study, he identified 65 sites with Dalton tools and five with Dalton-like tools. The southern boundary of these artifacts is Henderson County on the Trinity River, eastward through Nacogdoches and Rusk counties, northward from the Sabine River to the great bend of the Red River, and westward along the streams entering it from the Ouachita Mountain area.

Johnson emphasized that the heartland of these Dalton people was in Missouri and northern Arkansas, and these western Woodlanders were a frontier people. Interlopers were identified by Johnson as people of the Agate Basin, the Cody Complex, and Plainview cultures. The calling card of the Agate Basin people was the Packard point. The type site of these people was in eastern Wyoming. These were a Great Plains people who moved into the eastern Woodland primarily around the western edge of the Ozark Mountains in Oklahoma. Uncalibrated radiocarbon dates place these people living there between ca. 10,400-9,700 B.P.

The type site of the Cody Complex is the Horner site in northwestern Wyoming, four miles northeast of Cody. At this site, the diagnostic tools are the Eden and Scottsbluff points and Cody knives, all present at this buffalo butchering location. The Cody Complex is a cultural group particularly centered in the western Great Plains region. The artifacts of the Cody Complex are found from the plains of Canada to the Gulf of Mexico and from northeastern Utah to the Great Lakes in the east. This covers much of North America. The people were buffalo hunters. Most of the Cody Complex sites that have been excavated were major buffalo kill or butchering sites, and all had some or all of the diagnostic tools.

Johnson (1989) shows the location of 60 Cody Complex sites within his study area. The Scottsbluff point is by far the most numerous of the interloper points that have been found in Northeast Texas.

Johnson's essay includes comments about the Plainview people interlopers. He maps two sites in the Eastern Woodland margin of Texas where Plainview points were present. These are Horn Shelter No. 2 on the Brazos River and the Wilson-Leonard site in Williamson County. In southeastern Oklahoma, he locates three sites on rivers that flow southeast into the Red River. In East Texas, within the Eastern Woodlands, Johnson only marks a site in Rusk County where one Plainview point was identified by him. He states that other points in the literature described as Plainview may not actually be Plainview. As he was not able to examine them and verify this classification, he did not list the sites. Johnson believes other Plainview sites are within the Eastern Woodlands but have not yet been found. 


\section{Unidentified Points of the Bolton Collection}

Figures 25 and 26 illustrate unidentified points in the Bolton Collection. They have been grouped according to various physical attributes. These are listed in Table 5.

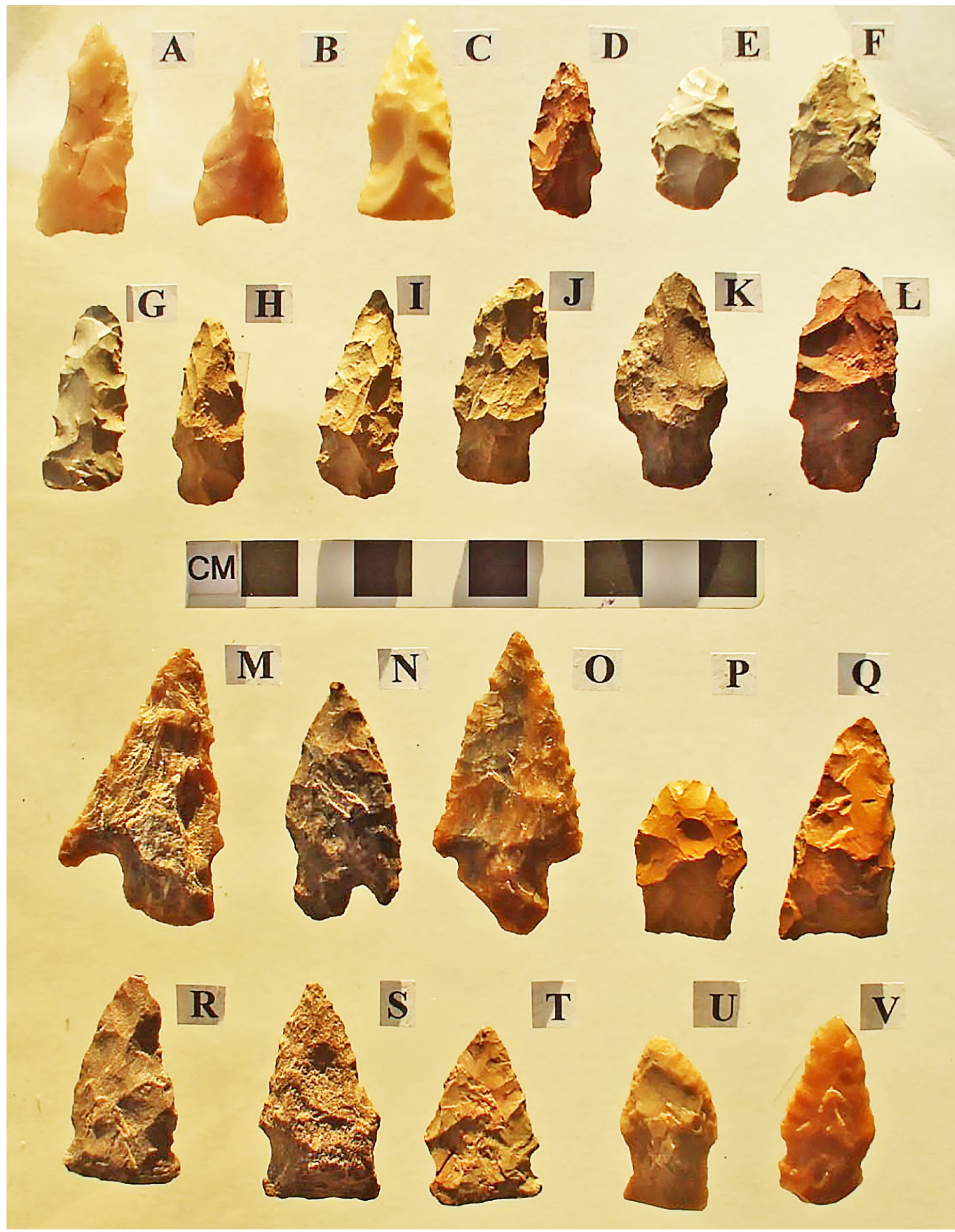

Figure 25. Unidentified points: A-F, small with different stem and body shapes; G-I, small side, notched; J-L, straight-stemmed; M-O, barbed and corner-notched; P-Q, wedge-shaped bases; $\mathrm{R}-\mathrm{V}$, side-notched, all made from snapped blade. 


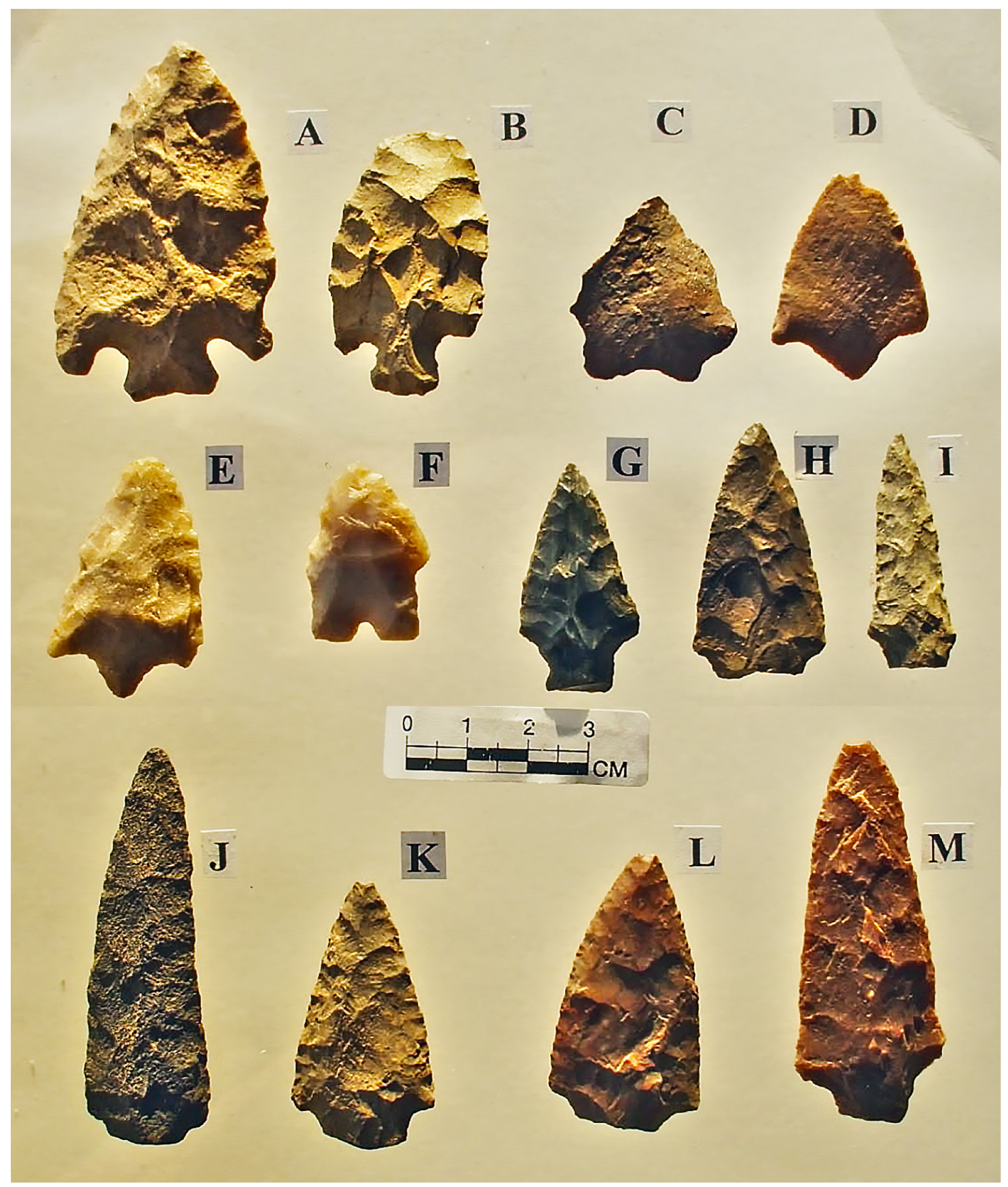

Figure 26. Unidentified points: A-B, corner-notched with expanding stems; C-D, unifaces; E, dart point that resembles the Bassett arrow point shape; F, reworked with intact stem; G-M, broken stems.

In Figure 25, points A-F are six of 20 (all under $38 \mathrm{~mm}$ length) with different stem and body shapes. Points A-C and F, and one not pictured, have smoothed or ground stems and bases. Four of these are a translucent novaculite. They all have a triangular to lanceolate shape. Johnson (1961) illustrated similar points that he identified as Sandy Creek that may have some relation to Paleoindian points east of the Mississippi River; I am unable to ascertain such a relation. Of these 20 points, seven are novaculite, two are jasper, six are non-local chert, and five are quartzite. 
Table 5. Unidentified dart points of the Bolton Collection.

\begin{tabular}{|c|c|c|c|c|c|c|c|c|}
\hline Description & 1 & 2 & 3 & 4 & 5 & 6 & $\mathrm{~N}$ & $\%$ \\
\hline Small mixed & 5 & & 2 & 8 & & 6 & 21 & 19.4 \\
\hline Small side notch & 5 & & & & 1 & & 6 & 5.6 \\
\hline Straight stem & 2 & 1 & 3 & 2 & & 1 & 9 & 8.3 \\
\hline Barbed corner notch & & 1 & & 1 & 1 & & 3 & 2.8 \\
\hline $\begin{array}{l}\text { Wedge base/ } \\
\text { Snapped blade }\end{array}$ & 1 & & 2 & & 1 & 1 & 5 & 4.6 \\
\hline $\begin{array}{l}\text { Side notched/ } \\
\text { Expanding stem }\end{array}$ & 3 & & & 4 & & & 7 & 6.5 \\
\hline Corner notch & 5 & 1 & 2 & 2 & & 8 & 18 & 16.7 \\
\hline Oddities & 2 & & & 1 & 1 & & 4 & 3.7 \\
\hline Large broken stem & 18 & & & 2 & & 15 & 35 & 32.4 \\
\hline Total & 41 & 3 & 9 & 20 & 4 & 31 & 108 & \\
\hline Lithics \% & 38.0 & 2.8 & 8.3 & 18.5 & 3.7 & 28.7 & & \\
\hline
\end{tabular}

1=local quartzite; $2=$ petrified wood; $3=$ jasper; $4=$ novaculite $5=$ Central Texas chert $6=$ unidentified chert

Points G-I are small side-notched points $(\mathrm{n}=6)$. Point $\mathrm{G}$ is made from Central Texas chert, two are of local quartzite, and three are of a non-local material. All are roughly flaked and noticeably thick.

Points J-L on Figure 25 are straight-stemmed points ( $n=9)$ of five different colors of chert. However, none of these points were assigned to the straight stemmed Kent variety of point.

Points M-O are barbed and corner-notched points $(n=3)$. They are all well-crafted with pressure edge flaking.

Points P-Q have straight to near straight bases and a basal wedge shape $(n=5)$. They are represented by four different colors of chert.

Points R-V represent seven points made from a blade after the blade had experienced a snap fracture. Small side-notches were added and the points were ready for use again. The five points pictured here have unmodified snap fractures. Two novaculite points had the snap rounded at the intersection of the flat snap and the blade edge before the side notches were added. There are three quartzite and four novaculite points in this group.

Figure 26 pictures additional unidentified points in the Bolton Collection. Points A-B are two of 18 points in this category. They are corner-notched with expanding stems. Their size ranges from lengths of 30-61 mm, widths of 19-39 mm, and thicknesses of 6-8 mm. Five are of local quartzite, one is petrified wood, two are jasper, two are novaculite, and eight are non-local chert.

Points C-D are unifacially flaked. They are made from large flakes of local quartzite. The reverse side is unmodified. The point $\mathrm{C}$ outline seems to resemble a San Patrice while point D resembles a Gary. Both flakes had been heat-treated.

Point E is a well-made point of a translucent "khaki"-colored novaculite. Its shape resembles the Bassett point of the Late Caddo period, but it is a much larger dart point. 
Point $\mathrm{F}$ is a light to medium gray chert with a well-defined line of demarcation between the two colors; the darker part is the more translucent, and the raw material is probably novaculite. The type is unknown, but it may be a reworked point with an intact stem.

Finally, points G-M on Figure 26 are seven of 35 points with broken or missing stems and are thus unidentified to type. Eighteen of these points are of local quartzite, two are novaculite, and 15 are of nonlocal cherts.

\section{A Comparison of the Bolton and the Yarbrough Collections}

Johnson (1961) wrote a detailed report and analysis of the collection of artifacts from the Yarbrough site (see Figure 1). It was excavated by the WPA between April 1, 1940, and September 1940. The site was on an oval floodplain knoll (2.7 acres in size) 150 feet south of the Sabine River. At the time of excavation, its maximum height above the floodplain was 10 feet.

The excavations were carried out in two locations on the knoll. Analysis Unit 1 consisted of 69 10 x $10 \mathrm{ft}$. squares near the middle of the knoll. Analysis Unit 2 started about 45 feet west of Unit 1. It consisted of $7710 \mathrm{ft}$. squares, which extended to the west end of the knoll. Excavation levels were 0-6 inches from the surface and then at 3 inch intervals to a depth of 54 inches below surface in each Analysis Unit. The stratigraphic analysis of the artifacts included 60 contiguous squares in Analysis Unit 1 and 58 in Analysis Unit 2. Turner (2006) illustrates the stratigraphic sequence of projectile points and axes from Analysis Unit 1.

The collection consisted of 835 identified dart points and eight arrow points. Selected artifacts from the site clearly include those of the Fourche Maline culture of the Woodland period as well as Archaic and Paleoindian periods.

The Yarbrough artifacts (from a 2.7-acre site) and those from the Bolton collection (from some 293 square miles of Camp County) are very similar in point type and quantity. To cement the similarities of the Gary points in the Bolton and Yarbrough collections $(n=388)$, Figure 5 compared the percentages of the Gary varieties for each collection. A comparison of the Woodland period point types from the Bolton and Yarbrough collections also show great similarities. For example, 88 percent of the Bolton points were Gary as were 85 percent in the Yarbrough collection. Edgewood points comprised 6 percent of the Bolton Collection Woodland period points and 13 percent at the Yarbrough site. The remaining point types of this period in both collections of Ensor, Elam, and Fairland were less than 1.5 percent. No Darl or Pogo points were in the Yarbrough collection.

Fifteen point types in the Bolton collection are of Late Archaic period age (see Table 1). The largest quantity of points were Yarbrough points with 39 percent in the Bolton collection and 55 percent in the Yarbrough site collection. Following this in quantity were Ellis, 7.4 percent of the Bolton Collection Late Archaic points and 11 percent at the Yarbrough site, and Wells, 11.5 percent in the Bolton Collection and 9.2 percent at the Yarbrough site. Kent points accounted for 12.9 percent of the Late Archaic points in the Bolton Collection and 5.8 percent at the Yarbrough site. Other Late Archaic points in both collections are Bulverde, Hill, and Trinity types. Included in the Yarbrough site collection but not in the Bolton Collection were Marshall, Yantis, Wesley, Palmillas, and Lone Oak points.

The only Middle Archaic points in the Yarbrough collection were Morrill. There were 33. The Bolton Collection of points included Morrill, Calf Creek, Johnson, and Evans types (see Table 1 for the quantity of these points in the Bolton collection). There were no Early Archaic points in the Yarbrough group and only Breckenridge and Hoxie types in the Bolton collection. 
The Paleoindian points in the Bolton Collection are Clovis, Dalton, Plainview, Scottsbluff, Eden, San Patrice, and Wilson. The Yarbrough collection contained two Clovis, three Meserve, three Sandy Creek, and seven miscellaneous points with Paleoindian attributes. Four of these seven points had ground stems and bases, short blades, inconspicuous shoulders, and were generally lanceolate in form.

The similarities of point forms at these two locations confirms the habitation by people of the same culture and projectile point technology.During the Early Archaic and Paleoindian periods, both regions were visited by a few explorers mostly from Central Texas who left a few of their dart points behind.

\section{A Comparison of the Cherts of the Bolton and Middlebrook Collections of Dart Points}

Artifacts from the Camp County Bolton Collection have been compared with those from sites in the Post Oak Savanna, the Blackland Prairie, the Cypress Creek watershed, and the middle Sabine River region. One area remains to the south, deep in the Pineywoods of East Texas, namely Nacogdoches County, 100 miles south-southeast of Camp County (see Figure 1).

In 2016, Tom Middlebrook (2016 personal communication) made a study of the raw materials of the dart points used by the indigenous people of Nacogdoches County. He separated 880 points into the six varieties, as in the Bolton collection. A comparison showing the percentages of the different raw materials in the two collections is:

$\begin{array}{lll} & \begin{array}{l}\text { Camp Co. } \\ (\mathrm{n}=1308)\end{array} & \begin{array}{l}\text { Nacogdoches Co. } \\ (\mathrm{n}=880)\end{array} \\ \text { Quartzite } & 57 \% & 2.6 \% \\ \text { Petrified Wood } & 0.1 \% & 39.1 \% \\ \text { Jasper } & 7.9 \% & 25.0 \% \\ \text { Novaculite } & 11.0 \% & 0.1 \% \\ \text { Central Texas } & 5.7 \% & 22.2 \% \\ \text { Source Unknown } & 18.0 \% & 10.3 \%\end{array}$

Interesting observations may be made from this: (1) the local people used the raw materials readily available, i.e., quartzite to the north, where it is plentiful, and petrified wood to the south where it is plentiful, and quartzite is not; (2) novaculite points are in Camp County, much closer to their source in the Ouachita Mountains of Oklahoma and Arkansas, and Red River gravels, but a much longer distance to Nacogdoches County where its use was insignificant; (3) local Jasper pebbles were available in both locations and were used; (4) Central Texas chert use was more prevalent in Nacogdoches County, much closer to its source than Camp County; (5) chert of unidentified sources is present in both locations and was used; and (6) although petrified wood pebbles were available in Camp County it was seldom used, as the local quartzite was a better material for knapping.

\section{Arrow Points}

There are 14 arrow points in the Bolton collection. Seven of these points are Alba (or Alba-like), two are Catahoula, one is unclassified and made of jasper, one Steiner, two preforms, and one broken and unidentified arrow point. Twelve of these points are made of local quartzite, one is local jasper, and one is a non-local unidentified chert. Table 6 lists the material of the arrow points. 
Table 6. Arrow points of the Bolton collection.

\begin{tabular}{lllllll}
\hline Description & 1 & 2 & 3 & 4 & 5 & 6 \\
\hline Alba & 7 & & & & & 7 \\
Catahoula & 2 & & & & 2 \\
Steiner & 1 & & & 1 & 1 \\
Preforms & 2 & 1 & & & 2 \\
UID & & & & & \\
\hline
\end{tabular}

\section{Tools}

Tools in the collection are illustrated in Figure 27. Ten tools are shown, eight of which are drills or perforators. Four drills are quartzite, two are on a non-local gray chert, and two are a red jasper. The largest tool (Figure 27A), $47 \mathrm{~mm}$ long, is a gouge fashioned from the blade of a light gray novaculite dart point. The Albany scraper (Figure 27B) has a right hand bevel on one edge and is bifacially flaked on the other. It retains some cortex on one face but none on the other.

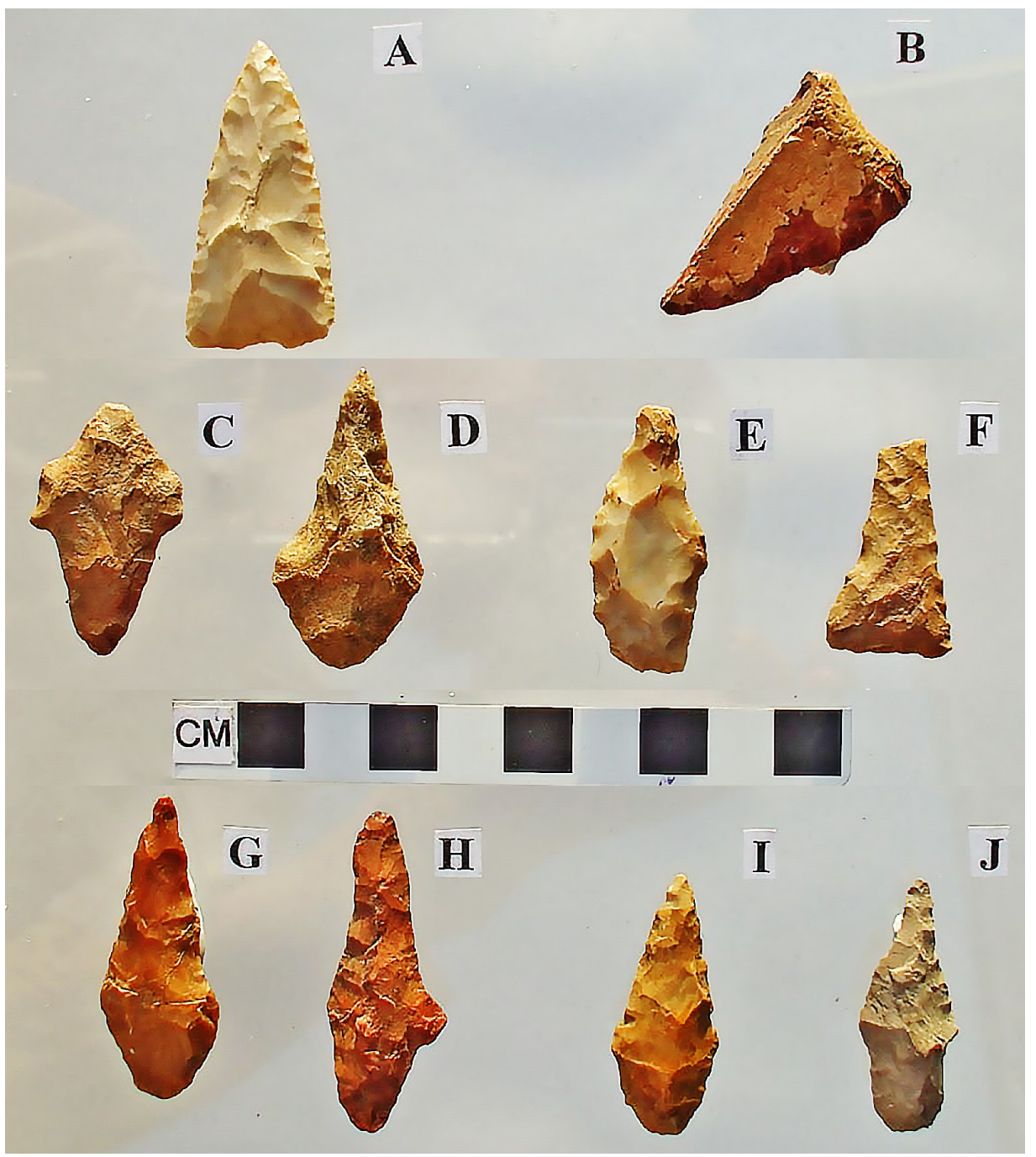

Figure 27. Tools: A, gouge; B, Albany scraper; C-J, drills or perforators. 
Table 7. Tools of the Bolton Collection.

\begin{tabular}{|c|c|c|c|c|c|c|c|}
\hline Description & 1 & 2 & 3 & 4 & 5 & 6 & $\mathrm{~N}$ \\
\hline Drills & 4 & & 2 & & & 2 & 8 \\
\hline Albany Scraper & & & 1 & & & & 1 \\
\hline Gouge & & & & & 1 & & 1 \\
\hline
\end{tabular}

Drill C on Figure 27 appears to have been fashioned from a Gary, variety Kaufman point, based on stem shape. Both the stem and the drill end seem equally smoothed. Drill D also has equal smoothing on the stem and blade. Drill E has a 30-35 degree counter-clockwise twist of the blade when looking from the tip. Small flakes are broken away at the blade edge. Artifact $\mathrm{F}$ has no base or blade wear, and could be an arrow point preform. Drill $\mathrm{G}$ has small flake breakages at the blade edge. Drill H appears to have been made from a Gary, variety Runge point. Both the stem and blade are lightly smoothed. Drill I has a slightly roughened blade edge and is not smoothed from use. Drill $\mathrm{J}$ has no drill wear. Table 7 lists the raw material of these artifacts.

Two objects, not tools, included in this collection, but not pictured, are two clear quartz crystals. One is roughly cubic with faces about $14 \mathrm{~mm}$ square and a thickness of $10 \mathrm{~mm}$. The other is 50 percent of a stream-tumbled egg-shaped crystal. The broken face is extremely clear. The maximum dimension is 29 $\mathrm{mm}$. These crystals probably came from the Ouachita Mountains in Arkansas

\section{The Galt Biface}

The Galt biface, in the Bolton collection, is pictured in Figure 28. Thurmond (1990) defined this artifact as a type, and listed seven known sites where it had been found at the time of his publication. These bifaces are associated with burials of the Late Caddo Titus and Belcher phase peoples. He postulated they were probably badges of office, and this is likely correct, as they are extremely rare and seem to occur in graves of individuals with an abundance of other offerings. Thus, they most likely belonged to important personages. Thurmond's (1990:35) description of their manufacture is as follows:

Each specimen was executed by the removal of broad, thin collateral flakes to produce nearly parallel surfaces exhibiting very little convexity. Numerous short, narrow flakes were then removed to produce a very steep biface beveled edge around the entire specimen. This final edge trimming was very carefully controlled so the bevels are of very uniform width and edge sinuosity is minimal.

This description of the flaking technique fits the pictured biface perfectly. The existence of the Bolton Collection biface was not known to Thurmond at the time of his publication. The Bolton Galt Biface measures $192 \mathrm{~mm}$ long by $63 \mathrm{~mm}$ at its maximum width. Nineteen thickness measurements yielded two of $5 \mathrm{~mm}$ and 17 of $4 \mathrm{~mm}$. The material is a Georgetown chert. It would be extremely interesting to know at which specific sites these artifacts were made in Central Texas. I believe this artifact came from the Harold Williams site (Turner et.al. 2002), as Mr. Bolton had several Titus phase pottery vessels from it in his collection.

\section{Bifaces}

Figure 29 pictures four large bifaces from the Bolton collection, and all are of Central Texas chert. At the bottom of the figure is a large trade biface blank of Georgetown chert. The dimensions are $115 \times 83$ $\mathrm{mm}$ in length and width with a maximum measured thickness of $20 \mathrm{~mm}$. It appears to have been used as a chopper, as all edges are battered and show edge crushing. A similar trade blank is pictured in Turner et al. (2011:21). 


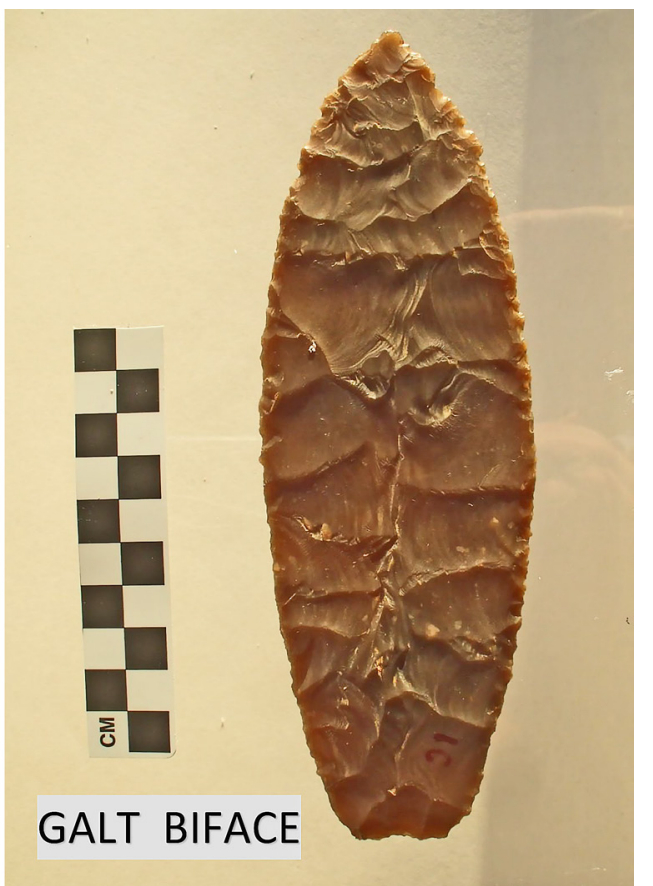

Biface 3C on Figure 29 is a dark gray to near-black chert and may be a raw material related to Georgetown sources. One side shows a swatch of cortex remaining. The dimensions are $100 \times 75 \mathrm{~mm}$ with a thickness of $10-11 \mathrm{~mm}$. The complete periphery is flaked perpendicular to the edge with both large and small chipping flakes. The small stem at the top is too small and poorly shaped for attachment of a handle. No edge smoothing can be detected. It was probably used as a knife.

Biface $2 \mathrm{C}$ is also a dark gray to near-black chert likely related to Georgetown chert. Its dimensions are 133 x 34 $\mathrm{mm}$ in length and width, with a thickness of 5-7 mm near the base, tapering toward the tip. The artifact has a steep left-hand bevel on both blade faces that intersects the blade face 3-4 $\mathrm{mm}$ from the edge; the beveling is probably from resharpening. The edges have very minor smoothing, and are somewhat jagged from small flake breakage. The base chipping is similar to that of the edges, but it is not beveled. I identify this artifact as a knife.

Figure 28. Galt biface from the Bolton Collection.

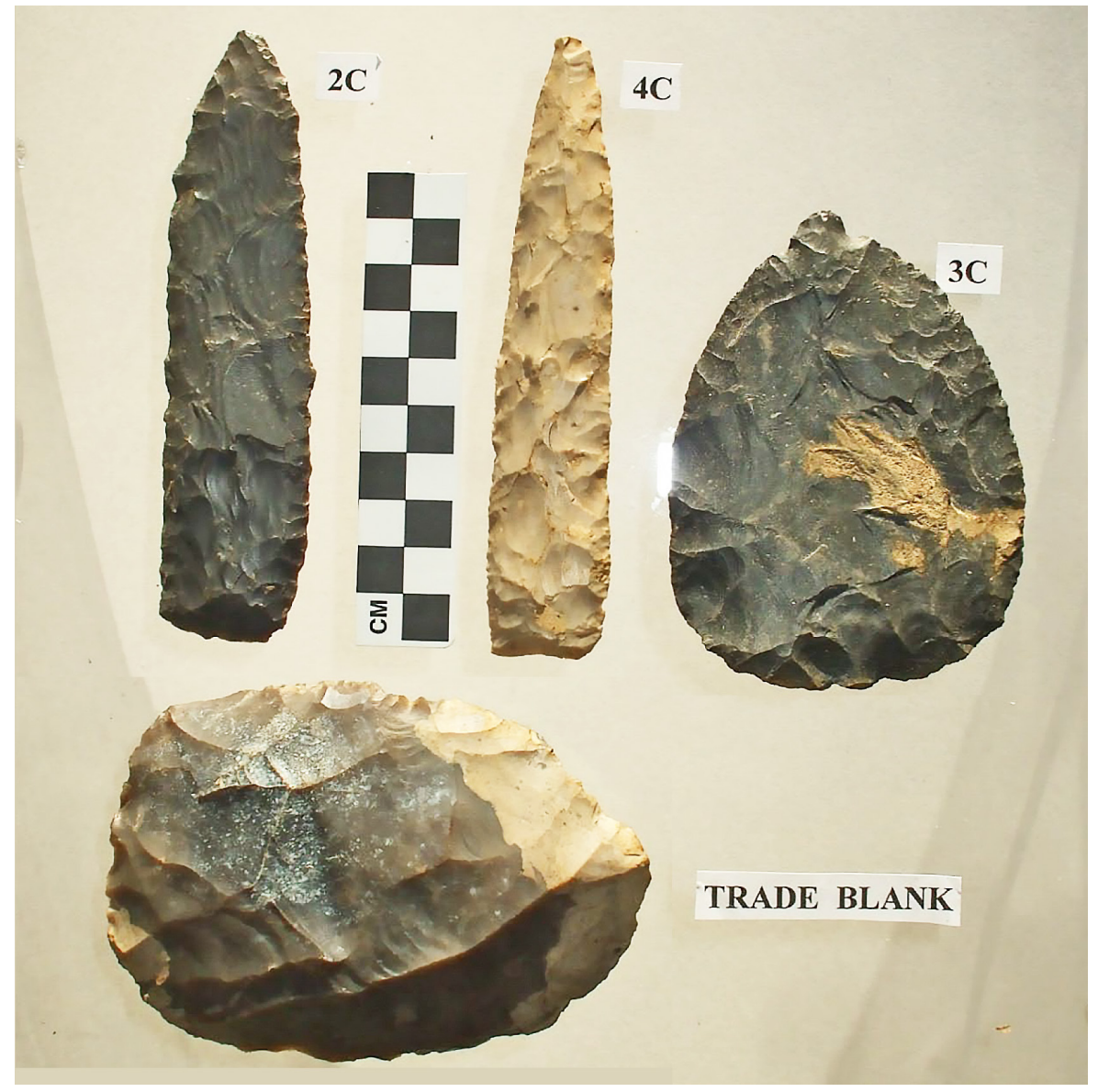

Figure 29. Large bifaces in the Bolton Collection of Central Texas chert. 
Biface 4C, a lanceolate shape, has dimensions of $132 \mathrm{~mm}$ in length, a width of $26 \mathrm{~mm}$ at the base, and a maximum thickness of $10.5 \mathrm{~mm}$ at the base but tapering to $6 \mathrm{~mm}$ near the tip. The chert is not local to East Texas and is a light gray-tan color that is almost lustrous in appearance. There is a pronounced median ridge on each blade face from the base to the tip. This may be a spear point with the stem broken away.

An inspection of these four bifaces with $385 \mathrm{~nm}$ ultraviolet light showed that Biface 4C fluoresced a bright white. The trade blank fluoresced with a slightly mottled yellow glow. Bifaces $2 \mathrm{C}$ and $3 \mathrm{C}$ did not fluoresce. The non-response to this ultraviolet excitation has also been noted for other black chert artifacts in the Bolton Collection.

\section{Knives}

Bifaces classified as knives are shown in Figure 30. Raw material identifications for these categories are provided in Table 8 .

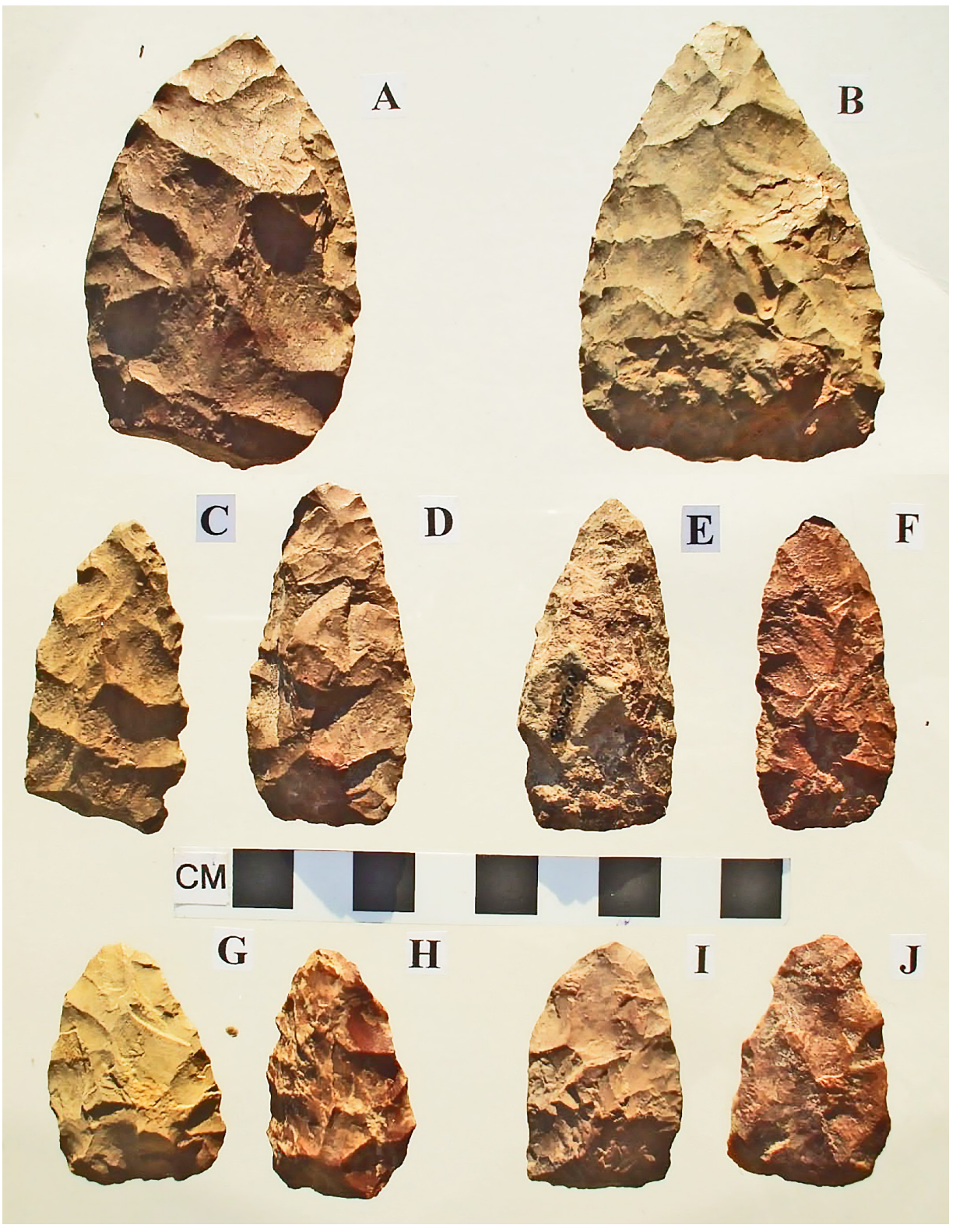

Figure 30. Knives: A-B, large unnamed; C-F, Group I; G-J, Group II. 
Table 8. Knives of the Bolton Collection.

\begin{tabular}{|c|c|c|c|c|c|c|c|c|}
\hline Category & 1 & 2 & 3 & 4 & 5 & 6 & $\mathrm{~N}$ & Percent \\
\hline Large Ovate & 2 & & & & & & 2 & 6 \\
\hline I & 4 & & & & & & 4 & 13 \\
\hline II & 6 & & 1 & & & 2 & 9 & 29 \\
\hline III & & & & 1 & & 1 & 2 & 6 \\
\hline IV & 5 & & & & & & 5 & 16 \\
\hline $\mathrm{V}$ & 2 & $1 *$ & & 1 & & 2 & 6 & 19 \\
\hline VI & 1 & 1 & & & & 1 & 3 & 10 \\
\hline Total & 20 & 2 & 1 & 2 & & 6 & 31 & \\
\hline Lithics \% & 65 & 6 & 3 & 6 & & 19 & & \\
\hline
\end{tabular}

*=Ferruginous Sandstone; $1=$ local quartzite; $2=$ petrified wood; $3=$ jasper; $4=$ novaculite; $5=$ Central Texas chert; $6=$ unidentified chert

Large biface A is a light maroon local quartzite. Its dimensions are 74 x $45 \mathrm{~mm}$ in length and width with a thickness of $14 \mathrm{~mm}$. The base has an off-center flat area that could have resulted from a large stem break. I have never seen such an East Texas tool. The blade has a counter-clockwise twist of roughly 15 degrees when viewed from the tip. Smoothing at body flake intersections is apparent as is edge smoothing completely around the periphery except at the snap fracture. This was a much-used knife. To acquire this edge smoothing one possible use of this tool would have been the cutting of the seedy heads of grasses on a cutting surface of either wood or stone. As it severed the stems, the tool came in contact with the cutting surface. After repeated use, this would produce edge smoothing.

Large biface B on Figure 30 is a light gray quartzite with occasional streaks of tan. The dimensions are 73 x $48 \mathrm{~mm}$ in length and width with a thickness of $16 \mathrm{~mm}$. The edges are not smoothed. The blade has a 5 to 10-degree twist when viewed from the tip. The base is flaked in a similar way to that of the blade edges. This is a well-made knife but shows little use.

In his analysis of the artifacts from the Yarbrough site, Johnson (1961) analyzed 351 bifacial artifacts. These he classified as knives, as they all had at least one percussion-flaked cutting edge. Johnson divided these into nine groups (I through IX), and I have separated 29 similar knives of the Bolton collection into Groups I-VI. Some or all of these knife groups were also present in the Manton Miller site (Johnson 1961) in Delta County, the Upper Rockwall and Glen Hill sites (Ross 1966) in Rockwall County, the Pecan Springs site (Sorrow 1966) in Ellis County, the Tankersley Creek site (Young 1981) in Titus County, and the Lizzie Hill site (Perttula 2014) in Camp County. Some or all of Johnson's knife forms are present in these Late Archaic and Woodland sites, and they are tools probably contemporaneous with the manufacture and use of Gary point.

In Figure 30C-F are the four Group I knives in the Bolton Collection. They have convex edges and a somewhat lanceolate shape with straight bases. They are all percussion-flaked and show edge wear though not edge smoothing. The lengths are between $49-55 \mathrm{~mm}$, widths are between 22-29 $\mathrm{mm}$, and thicknesses are 10-12 mm. All were worked from both faces. Three are made on a local maroon quartzite, and the fourth is a light tan quartzite.

Group II knives ( $\mathrm{n}=9$, see Figure 30G-J) are triangular, to near-triangular, in shape. The edges are straight to convex, the bases are straight to slightly rounded, and percussion flaking was used in shaping the knives. The lengths vary between 35-40 mm, widths between $23-30 \mathrm{~mm}$, and thicknesses between 
5-11 mm. Two of the group are non-local chert; one of these is unifacial. The others are bifacially flaked and have edge wear. One of the Group II knives is on a local red jasper, and the remaining Group II knives are local quartzite.

Group III knives ( $\mathrm{n}=2$ ) are tear-drop shaped (Figure 31A). One is a gray novaculite, and the second knife, not illustrated and unifacially flaked, is a "dirty" gray non-local quartzite that may be from a Ouachita Mountain source. The lengths of these two knives are 37 and $38 \mathrm{~mm}$, the widths are 21 and 24 $\mathrm{mm}$, and they are 5 and $7 \mathrm{~mm}$ thick, respectively. The edges, including the rounded bases, show wear.

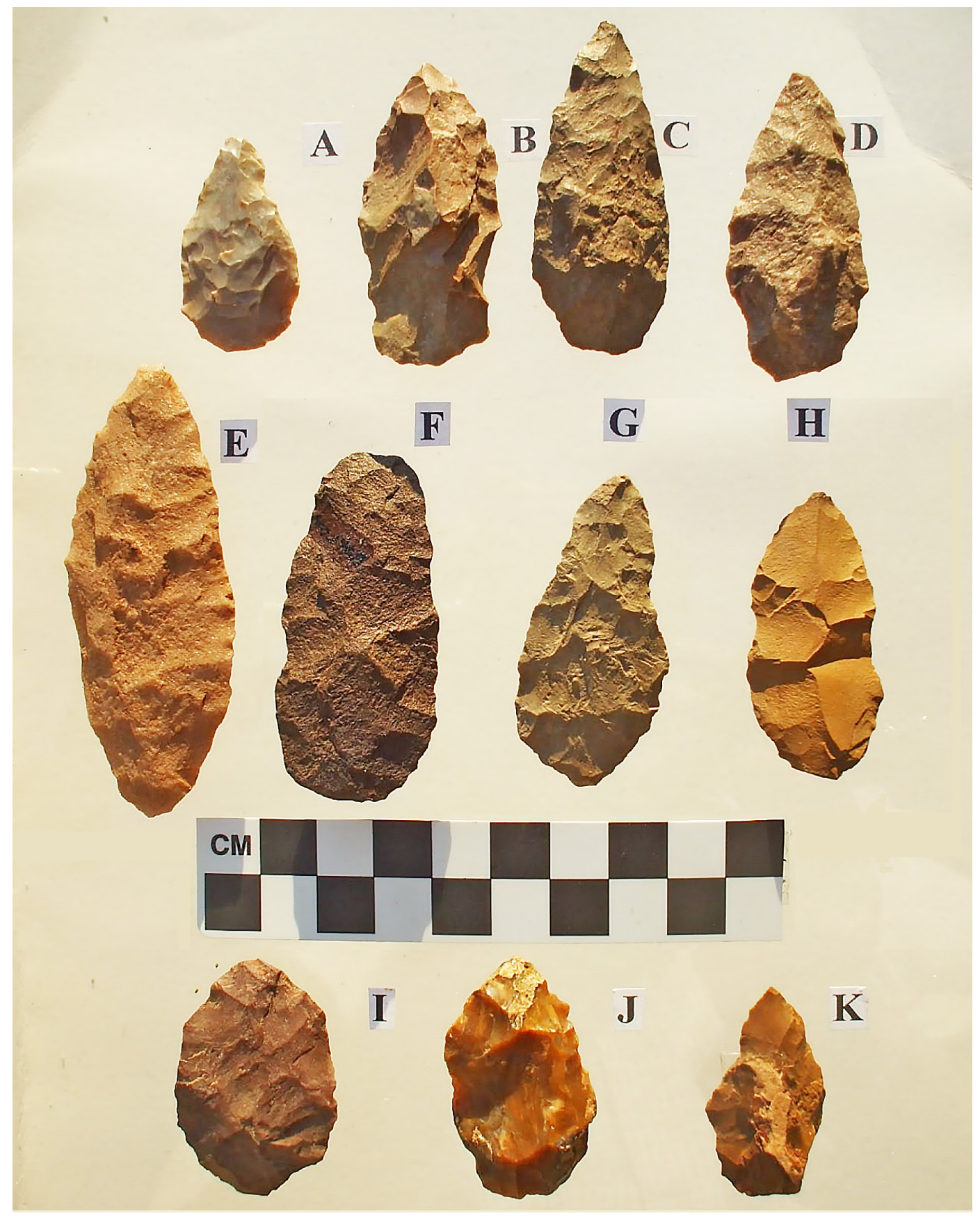

Figure 31. Knives: A, Group III; B-D, Group IV; E-H, Group V; I-K, Group VI. 
Group IV (see Figure 31B-D) knives ( $\mathrm{n}=5$ ) are made from quartzite and have particularly large flake removals. Their lengths are between 43 and $57 \mathrm{~mm}$, widths between 24-34 mm, and thicknesses between $12-17 \mathrm{~mm}$. These are the thickest of the knife groups. The bases are rounded, and all edges have wear, including the rounded base.

Group V (see Figure 31E-H) knives $(\mathrm{n}=6)$ are generally bi-pointed although one end is more pointed than the other. The edges are convex. Lengths are between 36-78 mm, widths are between 21-31 mm, and thicknesses are between $6-10 \mathrm{~mm}$. The longest knife (see Figure 31E) is a red-tan grainy quartzite of non-local origin. It is well-shaped and flaked as is F, a local ferruginous sandstone knife. All six Group V knives have some edge wear. Of the four other Group V knives, two are on local quartzite, and two are on a tan-colored fine-grained non-local chert.

Group VI knives (see Figure 31I-K) are generally ovate-shaped and extremely crudely flaked. The lengths of these three knives are between 41-48 mm, their widths are between 21-29 mm, and thicknesses between 9-12 mm. One knife is a maroon-colored quartzite, one is of petrified wood, and one is on a nonlocal chert.

Johnson's Groups VII- IX included slabs of petrified wood, worked on one side or bifacially, medium-sized knives of petrified wood of triangular or sub-triangular shape, and a large group of specimens that could not be placed in any of the eight other groups. None of the Bolton Collection knives were placed in Groups VII-IX.

\section{Conclusions}

The Camp County artifacts of the Woodland period include those that identify the local people as belonging to the Fourche Maline culture. The Gary points of this culture are by far the dominant point type in the collection. An examination of the relatively few other points that date to this period, based on the raw material identifications, show only a few that were made using the local raw materials. The spear points of this era, based on their raw material, were traded in from Central Texas and the Ouachita Mountains of southeastern Oklahoma or southwestern Arkansas. An analysis of the Gary points establishes that the local quartzite, as well as the local jasper, were the raw materials of choice of the local Woodland population. Novaculite and non-local cherts were present in the Woodland period dart points and likely came into the region as completed artifacts.

The aboriginal peoples that made and used Yarbrough points, based on their use of quartzite and the quantity of this point type, were the largest group of local inhabitants during the Late Archaic period. The Middle Archaic period was characterized by a sparse aboriginal population. The Calf Creek point people, from Central Texas and Oklahoma, were certainly visitors to the region but not local inhabitants. The makers of the Morrill points, a product of a probable indigenous group, were the first noted, in this study, to employ heat treating of the local quartzite. During the Early Archaic and Paleoindian periods, the points in this collection are mostly from Central Texas sources or cherts of unknown origin, but none are of local chert.

\section{Acknowledgements}

I thank Bo Nelson and Mark Walters for helping me identify novaculite, Mark for telling me of the ultraviolet inspection of cherts as an aid in determining their origin, and Dr. Tom Middlebrook for providing me with an ultraviolet source. Dr. Clark Wernecke sent me two papers concerning eared Scottsbluff points from Wisconsin. Vernon Holcomb loaned spear points from the Northeast Texas Rural Heritage Museum, in Pittsburg, Camp County, for photographing. I also am indebted to my daughter, Dr. Nancy Turner, for editing this article, as well as Appendix 1, for sentence structure and punctuation. Also, I appreciate the computer expertise of Richard Sanders and Sam Turner, who unraveled the computer problems involving the figures and tables in this article. 


\section{References Cited}

Banks, L. D.

1990 From Mountain Peaks to Alligator Stomachs. Memoir No. 4. Oklahoma Anthropological Society, Norman.

Bousman, C. B., B. W. Baker, and A. C. Kerr

2004 Paleoindian Archeology in Texas. in The Prehistory of Texas, edited by T. K. Perttula, pp. 15-100. Texas A\&M University Press, College Station.

Carpenter, S. and P. Paquin

2010 Towards a Genealogy of Texas Stone Projectile Points. Bulletin of the Texas Archeological Society $81: 153-175$.

Collins, M. B., D. M. Yelacic, and C. B. Bousman

2011 "Realms," A Look at Paleoclimate and Projectile Points in Texas. Bulletin of the Texas Archeological Society 82:3-30.

Duffield, L. F.

1963 The Wolfshead Site: An Archaic-Neo-American Site in San Augustine County, Texas. Bulletin of the Texas Archeological Society 34:83-141.

Evans, O. F.

1958 The Frisco Flint Quarries. Bulletin of the Oklahoma Anthropological Society 6:33-36.

Ellis, L. W.

2013 Woodland Ceramics in East Texas and a Case Study of Mill Creek Culture Ceramics. Bulletin of the Texas Archeological Society 84:137-180.

Hill, M. G.

1994 Paleoindian Projectile Points from the Vicinity of Silver Mound (47JA21) Jackson County, Wisconsin. Midcontinental Journal of Archaeology 19(2):235-246.

Johnson, L.

1961 The Yarbrough and Miller Sites of Northeastern Texas, With a Preliminary Definition of the La Harpe Aspect. Bulletin of the Texas Archeological Society 32:141-284.

1989 Great Plains Interlopers in the Eastern Woodlands During Late Paleoindian Times. Report 36. Office of the State Archeologist, Texas Historical Commission, Austin.

Kuehn, S. R. and J. A. Clark

2012 An Analysis of Faunal Remains from Three Late Paleoindian (Lake Poygan phase) Sites in EastCentral Wisconsin. Illinois Archeology 24:123-132.

Nelson, B. and T. K. Perttula

2003 Archeological Survey Along the Lake Bob Sandlin Shoreline, Camp, Franklin, and Titus Counties, Texas. Report of Investigations No. 46. Archeological \& Environmental Consultants, LLC, Austin.

Perttula, T. K.

2013a The Sam D. Carpenter Garden Plot Site (41CP496), Camp County, Texas.Journal of Northeast Texas Archaeology 40:47-52.

2013b Paleoindian to Middle Archaic Projectile Points from East Texas. Journal of Northeast Texas Archaeology 42:33-46.

2014 The Horton Site (41CP16) in the East Texas Pineywoods and the Lizzie Hill Site (41CP494), Camp County Texas. Journal of Northeast Texas Archaeology 43:47-63.

2016 The Archaeology of the Archaic Periods in East Texas. Journal of Northeast Texas Archaeology 62:61-89.

n.d. The Distribution of Calf Creek Series Sites and Points in East Texas. MS on file with the author. 
Perttula, T. K. and M. Miller

2014 Archaeological Investigations at the Kitchen Branch (41CP220), B. J. Horton (41CP20, and Keering (41CP21) Sites, Big Cypress Creek Basin, Camp County, Texas. Technical Report of Investigations No. 88. 2 Vols. AmaTerra Environmental Inc., Austin.

Perttula, T. K. and W. L Young

2012 Trends in Archaic and Woodland Period Use of the Middle Sabine River Basin Based on Dart Point Proportions. Journal of Northeast Texas Archaeology 37:23-30.

Ray, J. H.

2016 To The Point Breckenridge. In Projectile Point Types in Missouri and Portions of Adjacent States. Bulletin of the Missouri Archeological Society, Missouri State University, Springfield,

Ritzenthaler, R. E.

1967 A Guide to Wisconsin Indian Projectile Point Types, Vol. 11. Milwaukee Public Library, Milwaukee, Wisconsin.

Ross, R. E.

1966 The Upper Rockwall and Glen Hill Sites, Forney Reservoir Texas. Papers No. 9. Texas Archeological Salvage Project, The University of Texas at Austin.

Schambach, F.

1982 An Outline of Fourche Maline Culture in Southwest Arkansas, In Arkansas Archeology in Review, edited by N. L. Trubowitz and M.D. Jeter, pp 132-197. Research Series No. 15. Arkansas Archeological Survey, Fayetteville.

2002 Fourche Maline: A Woodland Period Culture of the Trans-Mississippi South. In The Woodland Southeast, edited by R. C. Mainfort, Jr. and D. G. Anderson, pp. 91-112. The University of Alabama Press, Tuscaloosa.

Shafer, H. J. and M. Walters

2010 The Browning Site (41SM195A) Lithics: Considering Patterns of Identity and Interaction Through Lithic Analysis. Bulletin of the Texas Archeological Society 81:127-151.

Sorrow, W. S.

1966 The Pecan Springs Site, Bardwell Reservoir, Texas. Papers No. 10. Texas Archeological Salvage Project, The University of Texas, Austin.

Suhm, D. A. and A. D. Krieger, with contributions by E. B. Jelks

1954 An introductory Handbook of Texas Archeology. Bulletin of the Texas Archeological Society 25:1-582.

Suhm, D. A. and E. B. Jelks (editors)

1962 Handbook of Texas Archeology: Type Descriptions. Special Publication No. 1, Texas Archeological Society and Bulletin No. 4, the Texas Memorial Museum, Austin.

Thurmond, J. P.

1990 Archeology of the Cypress Creek Drainage Basin and Northwestern Louisiana. Studies in Archeology 5. Texas Archeological Research Laboratory, The University of Texas at Austin.

Turner, E. S., T. R. Hester, and R. L. McReynolds

2011 Stone Artifacts of Texas Indians. Third edition, Taylor Trade Publishing, Lanham, Maryland.

Turner, R. L.

2006 Hematite Axes of Northeast Texas. Bulletin of the Texas Archeological Society 77:1-32.

Turner, R. L. and J. E. Smith II, with contributions by T. K. Perttula, B. Nelson, M. Walters, and B. Gonzalez

2002 The Harold Williams Site (41CP10) and the Texas Archeological Society Field School of 1967. Bulletin of the Texas Archeological Society 73:1-68. 
Webb, C. H., J. L. Shiner, and E.W. Roberts

1971 The John Pearce Site (16CD56): A San Patrice Site in Caddo Parish, Louisiana. Bulletin of the Texas Archeological Society 42:1-49.

Young, W. C.

1981 Test Excavations at the Tankersley Creek Site, A Multi-Component Campsite in Titus County, Texas. Publications in Archaeology No. 22. State Department of Highways, Design Division, Austin. 


\title{
Appendix 1
}

\section{An Addendum to the Oliver Bolton Collection Report: Ultraviolet Light as a Tool in Dart Point Analysis}

\author{
Robert L. Turner Jr.
}

Two different sources of ultraviolet light were used in an inspection of the Bolton collection of lithic artifacts. The first was a "black light" incandescent bulb purchased from Walmart. The wave length emitted was not noted on the bulb or on the package. As these bulbs are used for the illumination of Halloween and party decorations in several colors, it is probable that a broad band of frequencies are emitted. In this appendix, "black light" refers only to the emission from this source.

The second source of ultraviolet light was from a medical tool that was provided to me by Dr. Tom Middlebrook. This device is a UV sterilizer, a hand-held wand that emits either a wave length of $254 \mathrm{~nm}$ or $365 \mathrm{~nm}$. The $254 \mathrm{~nm}$ frequency emits a white light akin to a flashlight, and I found that none of the lithics fluoresced at this excitation.

\section{Heat Treating Experiments with Quartzite Dart Points}

To confirm that heat treating results in a color change and makes the quartzite fluoresce, the following experiments were performed using the "black light." Five pairs of Gary dart points were selected. Each pair was of a similar quartzite by composition and color; only a visual inspection was made for these matches. In retrospect, a poor job was done in selecting the last pair for similarity. These points are pictured in Figure A1-1. The pairs were designated as 1 and 1s, 2 and 2s, etc. from left to right. The "s" designates the bottom

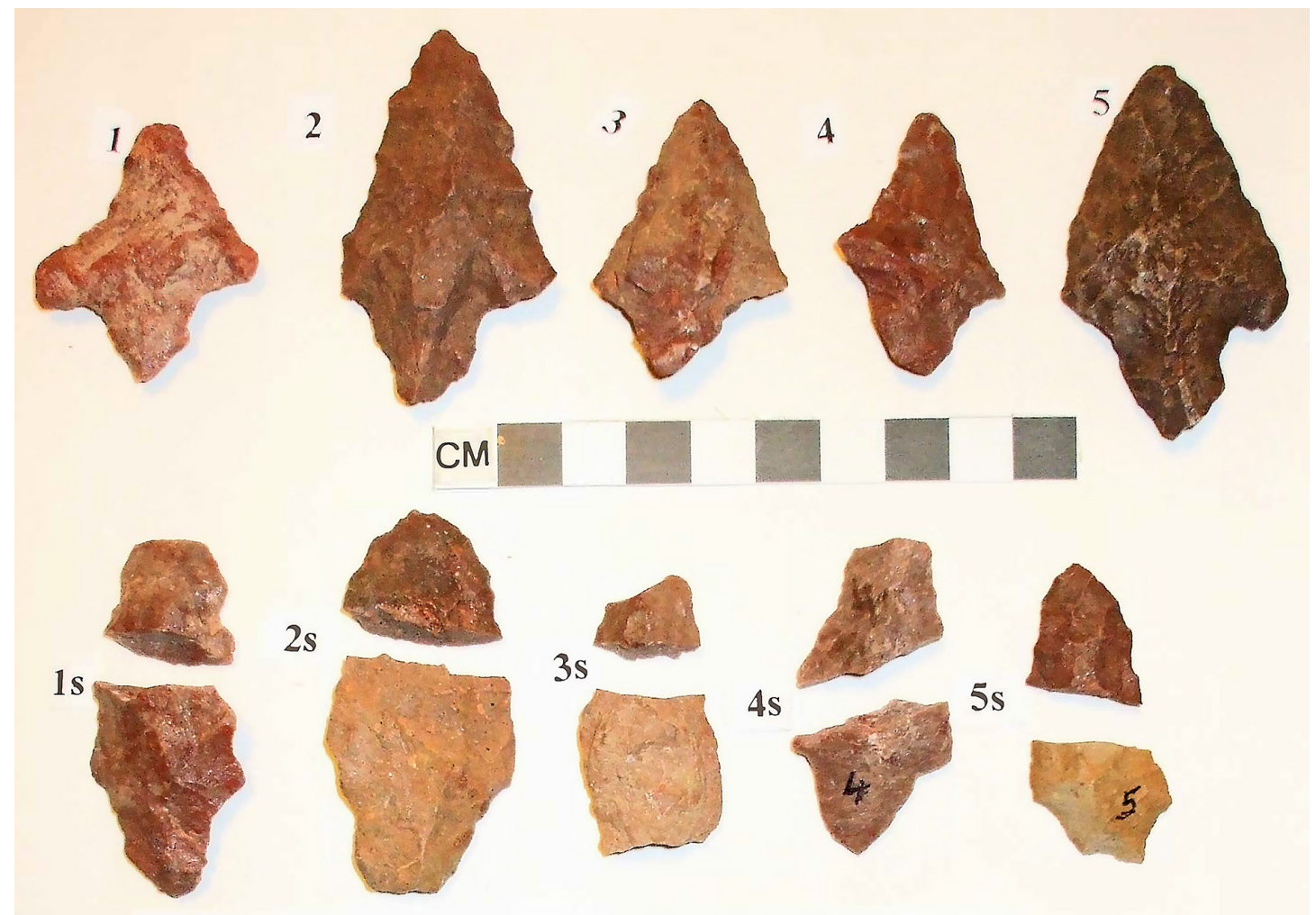

Figure A1-1. Heat-treated and non-heat-treated quartzite dart points. 
points. None of these 10 points fluoresced under ultraviolet light before heating. Before heating, the coloration of 1 and 1s was a gray maroon, 2 and 2s a light "dirty" brown, 3 and 3s a "khaki" brown, 4 and $4 \mathrm{~s}$ were a gray maroon, and 5 and $5 \mathrm{~s}$ a light yellow-tan.

The kitchen oven was heated to 500 degrees $\mathrm{F}$ and points 1 through 5 were placed on an aluminum cookie sheet and inserted. The points were removed in sequence, 1 through 5 , at $0.63,1.63,2.63,4.13$, and 5.13 hours, respectively. After cooling, an ultraviolet black light inspection showed a very slight spot or two of fluorescence or glow, but nothing definitive. This removal at different time periods was done to see where fluorescence might commence after heating.

The next heat treatment was with the same five points at 550 degrees $\mathrm{F}$ for 12 hours and then a two hour cool down within the oven. Points 1 and 4 did not appreciably change their appearance. The three other points became darker. To determine the effects of additional heat treatment, the same five points were heated at 550 degrees $\mathrm{F}$ for 12 hours and cooled within the oven until the next day.

The resulting change in points 1 through 5 is shown in Table A1-1, which compares the points after their first and second 12-hour heat treatments. The fluorescence increased, as did the darkening in coloration. This indicates that the molecular structure of the quartzite changed with the additional heat treatment in this test.

Table A1-1. Change in fluorescence and color after heat treatment.

After 1st 12 hour heating

Pt. 1 3/4 glow-no color change

Pt. 2 1/2 glow-darker color

Pt. 3 no glow-darker color

Pt. 4 1/4 glow-no color change

Pt. 5 no glow-darker color
After 2nd 12 hour heating

Pt. 1 good glow-no color change

Pt. 2 3/4 glow- darker color

Pt. 3 1/2 glow- darker color

Pt. 4 1/2 glow-no color change

Pt. 5 no glow-dirty black color

A better test for color change and fluorescent glow would have been to test the same piece of quartzite, not just similar pieces as in the test described above. Therefore, points $1 \mathrm{~s}$ through $5 \mathrm{~s}$ were snapped into distal and proximal pieces with a few small fragments. The distal ends were included with points 1 through 5 during the 12 hour second heating of those poiTable A1-2 shows the change of the distal ends of these points from their proximal ends (see also Figure A1-1).

Table A1-2. Change in fluorescence and color of distal ends of points $1 \mathrm{~s}-5 \mathrm{~s}$.

After 12 hour heating

Pt. $1 \mathrm{~s} \quad 1 / 4$ glow-no color change

Pt. 2s $3 / 4$ glow-darker color

Pt. 3s $1 / 2$ glow-darker color

Pt. 4s 1/4 glow-no color change

Pt. 5s good glow-major color change

Thus, on the same piece of quartzite, heat treatment darkened the color of three of these points and caused fluorescence to occur when viewed under ultraviolet light on all five specimens. Figure A1-1 
illustrates the points after heat treatment was complete. The top row of points was heat treated for a total of $24+$ hours, the middle row of distal ends for 12 hours, and the bottom row of dart point proximal ends were not heat treated.

In conclusion, these experiments show that for the 10 points tested, heat treating darkened the color toward a dark maroon (except for the points already that color, and which stayed the same). The maroon points acquired a mild glow, but all the others, except point 5 , had a more pronounced fluorescence.

Tables A1-1 and A1-2 list the amount of glow as various fractions of what I consider a "good glow," that is, the same fluorescence of a small lump of red clay. These fractions of fluorescent brightness are strictly mine; no two viewers would grade these levels of brightness the same. These are just indications that heat treatment has taken place. They also show that in this experiment, the longer a point was heated the brighter the fluorescence.

Wrought iron, such as railroad spikes, reach a dark red color when heated to 800 degrees F. Using a 1900 era farm forge (that includes an air blower), I spent many years demonstrating basic blacksmithing to elementary and middle school students. Fuel used included pine knots, charcoal, lignite, and anthracite coal. It is a problem, even with these amenities, to get the iron to 800 degrees $\mathrm{F}$ and sustain it there. The air must be kept flowing continuously. I believe the 500-550 degrees $\mathrm{F}$ oven temperature of this experiment would be the maximum temperature the native people could reach and sustain in their cooking fires. I imagine cobbles would have been amongst the coals of a cooking fire and might have remained for days until a knapper chose to knap the cobbles.

\section{5 nm Ultraviolet_Analysis of the Bolton Collection and Various Other Cherts}

All of the Bolton collection of dart points was also inspected under $365 \mathrm{~nm}$ ultraviolet light. Quartzite and jasper did not fluoresce under this excitation as various other samples of unidentified chert also did not; chert of Central Texas origin did. The fluorescent color ranged from white through yellow, and yellow with an orange tint, at various degrees of intensity.

When this inspection started, my presumption was that the Central Texas chert would be the only chert with this glow, and the glow would, therefore, be a positive identifier as to the origin of a dart point. Unfortunately, the Central Texas chert is not the only chert that exhibits this yellow-white fluorescence. Many of the points identified as being made from novaculite, particularly those of the translucent variety, exhibit a similar glow.

To compare the fluorescence of the novaculite points from the Ouachita Mountain region, with unidentified chert and Central Texas chert, several analyses were done using the Central Texas chert. From Central Texas sources the following samples were examined:

Twenty-seven cobbles and pebbles from gravel pits along the Colorado River, just southeast of Austin were examined. a, fresh flakes were taken from each sample and 100 percent fluoresced yellow or yellow-white; b, six cobbles from Singleton Hill in Blanco County were inspected. Five of these had sampling flakes removed in the past by the indigenous people. The flake scars were heavily patinated and did not glow. I removed new flakes. Four cobbles fluoresced a bright yellow and two a dull yellow. All were a gray chert; and c, 197 large primary flakes with cortex, large secondary flakes, smaller thinning flakes, and pressure flakes were examined under the ultraviolet light for fluorescence. These were from the spoil pile left by looters at a site on the former T-S Ranch in northern Hays County, along Bear Creek, a few miles southwest of Oak Hill. The purpose of this was to see if size, chert color, or source had any noticeable effect on fluorescence. Table A1-3 lists the fluorescent coloration of this chipping debris. 
Table A1-3. Fluorescent color of chipping debris from T-S Ranch.

\begin{tabular}{llllll}
\hline Flake color & No. & Flake Type & Yellow-white & $\begin{array}{l}\text { Yellow with } \\
\text { Orange tint }\end{array}$ & No Glow \\
\hline Gray & 13 & Lg. Primary & 5 & 5 & 3 \\
Light Gray & 10 & Lg. Primary & 8 & 2 & - \\
Dark Gray & 9 & Lg. Primary & 6 & 2 & 1 \\
Medium Gray & 10 & Lg. Primary & 6 & 4 & - \\
Near Black & 6 & Lg. Primary & 5 & 1 & - \\
Medium Brown & 10 & Lg. Primary & 5 & 5 & - \\
Medium Dk. Gray & 16 & Lg. Secondary & 11 & 49 & 31 \\
Gray Brown & 123 & Pressure & 43 & 73 & 35 \\
\hline Totals & 197 & & 89 & 37 & 18 \\
Percent & & & 45 & & \\
\hline
\end{tabular}

Most of the chert utilized for knapping at this site came from nearby sources and was a key factor for the location of this burned rock midden at this particular location. It was on the floodplain about $100 \mathrm{~m}$ west of Bear Creek at the intersection with the first terrace, $10 \mathrm{~m}$ higher in elevation. Irregular shapes of gray chert emerge along this landform. I surmise chert was also found in the numerous limestone cliffs bordering Bear Creek.

Table A1-3 shows that 45 percent of the chipping debris had a basic yellow fluorescence (which would include yellow-white, to almost white, and from pale to bright yellow). It also shows that 37 percent had an orange tint.

Fifty-four preforms, from the midden, were inspected under the $365 \mathrm{~nm}$ excitation. This included 16 complete, or nearly so, preforms, and the remaining were major proximal and distal fragments. Of these, 55 percent fluoresced various shades of yellow, and the remaining 45 percent fluoresced with an orange tint.

An attempt was made to see if age (when the chert was chipped, and the length of time it was exposed to the elements) had a bearing on whether the orange tint was always present or was a product of time. Eighteen points, including a corner tang knife, were collected from pasture land adjoining Bear Creek and within 0.5 miles of the T-S midden. These artifacts were not from cultivated fields so probably had been exposed to the elements for millennia. Nine points, which included a San Saba biface, were collected from the midden. These nine points had been within the midden, not exposed to the elements, and had probably been there since their manufacture. All 27 points were sorted as to quantity, variety, provenance, and their fluorescent glow under the $365 \mathrm{~nm}$ ultraviolet excitation.

From the surface collection, there was one Sabinal and two Fairland points. One Fairland point had an orange tint and the other two had a bright yellow-white tint. These three points date to the Transitional Archaic period.

From the Late Archaic period, eight artifacts were surface finds (one Montell, one Marcos, and the corner tang knife, also three Marshall and two Pedernales). Four of these had an orange tint. From the midden there were five points and the San Saba biface. Three of these had an orange tint.

From the Middle Archaic period five points were collected from the surface and three from the midden debris. The surface points included one Bulverde, three Martindale, and one Big Sandy. Of these points only the Big Sandy had an orange tint.Of the three Nolan points from the midden none had an orange tint. 
From the Early Archaic period, two points were collected from the surface and none from the midden. Each of the two Angostura points had the distal end of the blade snapped off. The exterior of these points produced no glow, the same as the flaking on the sampled cobbles from Blanco County that had probably been exposed on the surface for millennia. A view of the cross section of each point at the snap showed an approximately $0.25-0.5 \mathrm{~mm}$ weathered outer surface. The exposed section within this outer shell did glow with an orange tint. These blades must have been broken at a later date than their time of manufacture, or else the snapped end would be as weathered as their surface. As they were surface finds on pasture areas, it is possible they were broken by cattle or pickup trucks.

In order to better analyze and compare the fluorescence of the points described above, Table A1-4 presents these findings. This makes it easier to compare the effects of age, provenance, and exposure to the elements on fluorescence.

Table A1-4. T-S Projectile Points: their Age, Provenance, and Fluorescence.

\section{Transitional Archaic}

\begin{tabular}{|c|c|c|c|}
\hline Surface Quantity-Name & Color & Midden Quantity-Name & Color \\
\hline 1 Sabinal & Y-W & & \\
\hline 2 Fairland & O.T. \& Y-W & & \\
\hline \multicolumn{4}{|l|}{ Late Archaic } \\
\hline 1 Corner Tang & O.T. & 1 Montell & O.T. \\
\hline 1 Montell & O.T. & 3 Marcos & $\mathrm{Y}$ \\
\hline $1 \mathrm{Marcos}$ & & 1 San Saba & O.T. \\
\hline 3 Marshall & (2) Y-W; (1) O.T. & 2 Pedernales & O.T. \\
\hline 2 Pedernales & $\mathrm{Y}$ & & \\
\hline \multicolumn{4}{|l|}{ Middle Archaic } \\
\hline 1 Bulverde & W & 3 Nolan & $\mathrm{Y}$ \\
\hline 3 Martindale & $\mathrm{Y}$ & & \\
\hline 1 Big Sandy & O.T. & & \\
\hline \multicolumn{4}{|l|}{ Early Archaic } \\
\hline 2 Angostura & O.T. & & \\
\hline Total & & Total & \\
\hline 18 & $\begin{array}{l}8 \text { O.T.: } 10 \mathrm{Y} \\
44 \text { percent O.T. }\end{array}$ & 9 & $\begin{array}{l}3 \text { O.T.: } 6 \text { Y } \\
33 \text { percent O.T }\end{array}$ \\
\hline
\end{tabular}

Y=Distinct Yellow Glow; Y-W=Yellow-White Glow; W=White Glow; O.T.=Orange Tint Glow

The ultraviolet and "black light" analyses of the points in the Bolton collection were done in order to better identify the source of the artifacts. This analysis of the cobbles, flakes, chips, and points was made to see if it could be determined why 40 percent or less had an orange tint when fluorescing and most of the remainder had the original yellow-white color. All cobbles from the Colorado River gravels and Blanco County that I flaked were 100 percent yellow or yellow-white when fluorescing. These cherts were a gray color, sometimes with a brown shading. Thus, any newly made dart point of this material would have this same glow. The gravel pit cobbles originated in the Colorado River and its watershed (i.e., the effluent of the San Saba, Llano, and Pedernales rivers). To become cobbles at Austin, they experienced many miles and millennia of tumbling and grinding to attain their present shape and location. 
Not all cobbles from the gravel pits are suitable for knapping. A sizable amount is of near jet black to red fine-grained quartzite. To my knowledge these were not used for dart points in this area.

Table A1-3 showed that 37 percent of the T-S debris had an orange fluorescent tint. This debris had been covered in the midden since it was flaked. Forty-five percent had the yellow-white glow of the original chert from which it was flaked. Fifty-four preforms from the midden debris showed 45 percent with an orange tint and 55 percent with the original yellow-white glow. These percentages are quite similar, as both the lithic debris and preforms come from the same depositional environment within the midden.

Table A1-4 permits a comparison of the fluorescence of the points from within the midden and those collected from the surface. The surface-collected points with orange tint match in percent that of the midden debris. The nine points of the midden, (because of their low number), however, yield a less reliable percentage, but still show the same trend of the orange tint.

Some cobbles from the gravel pit (which had large flakes removed by natural banging about) fluoresced with an orange tint. When these flakes were removed or partially removed by flaking, the bright yellow-white fluorescence appeared under the new flake.

Based on the above listed provenances (whether the chert samples were underground protected from most of the elements, like the river cobbles or chipping debris), some molecular change or trace element produced the orange tint that was present on some but not all of the samples. Also, Table A1-4 confirms that the age of the dart points, whether from the midden or the surface, show the same orange tint as did the midden and river samples.

Figure A1-2 summarizes and compares the fluorescent colors using the $365 \mathrm{~nm}$ ultra-violet light of the Bolton collection points. The complete collection contained some 1380 points, and only 16 percent (or 223) of the total quantity fluoresced. From this it may be noted that the orange tint is a major identifying feature in separating the Central Texas and Ouachita Mountain cherts. It is also apparent that the glow of the unclassified raw material falls between that of the Central Texas sources and that of the novaculite of the Ouachita Mountains. A further study of the unidentified cherts ought to separate them better, but I will leave that to the future.

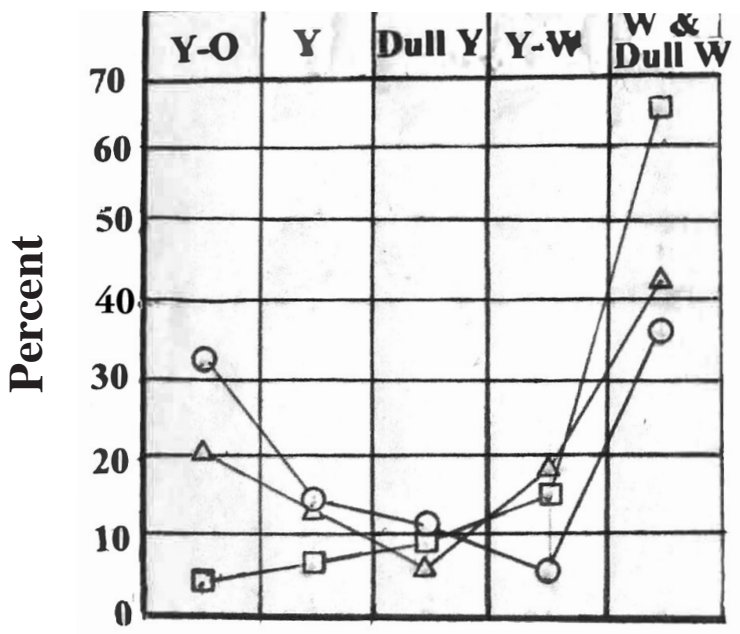

Pts. That Fluoresce

O Central Texas 62

Novaculite 96

$\triangle$ U.I.D. Opaque 65

Y-O: Yellow with Orange Tint

Y Yellow

Dull Yellow

Y-W Yellow-White

W\& Dull White

Figure A1-2. A comparison of the fluorescence of the Bolton collection dart points under $365 \mathrm{~nm}$ Ultraviolet light. 